\title{
BUKU AJAR MATA KULIAH PENDIDIKAN PKN SD KELAS AWAL
}

\author{
Oleh \\ Feri Tirtoni M.Pd
}

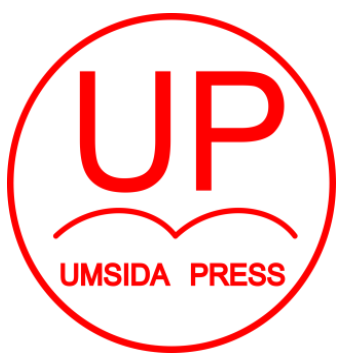

Diterbitkan oleh UMSIDA PRESS 


\section{BUKU AJAR}

\section{PENDIDIKAN PKN SD KELAS AWAL}

\section{Penulis :}

Feri Tirtoni M.Pd.

\section{ISBN :}

\section{Editor :}

Septi Budi Sartika, M.Pd

M. Tanzil Multazam, S.H., M.Kn.

\section{Copy Editor :}

Fika Megawati, S.Pd., M.Pd.

Design Sampul dan Tata Letak :

Mochamad Nashrullah, S.Pd

\section{Penerbit :}

UMSIDA Press

\section{Redaksi :}

Universitas Muhammadiyah Sidoarjo

J1. Mojopahit No 666B

Sidoarjo, Jawa TImur

Cetakan pertama, Juni 2019

(C) Hak cipta dilindungi undang-undang

Dilarang memperbanyak karya tulis ini dengan suatu apapun tanpa ijin tertulis dari penerbit. 


\section{KATA PENGANTAR}

Alhamdulillahirabbil'aalamin, Kalimat ini lah ungkapan puji syukur kehadirat Allah SWT Yang Maha pengasih dan penyayang. Kiranya tanpa karunia-nya, mustahil naskah buku "Pendidikan PKn SD kelas Awal" ini dapat terselesaikan tepat waktu. Latar belakang dari penyusunan buku ini adalah sebuah pemikiran bahwa PKn adalah sebuah mata pelajaran yang kelak akan menjadi sebuah pionir utama dalam upaya menerapkan sebuah perilaku berkarakter kepada siswa SD sehingga para guru maupun calon guru diharapkan memiliki sebuah kemampuan dalam melakukan sebuah inovasi dan strategi guna mengembangkan pembelajaran pada mata pelajaran PKn di sekolah dasar khusus nya di level SD kelas Awal. Pada saat ini kita sudah memasuki era digital di mana siswa sudah memiliki sebuah dunia yang berbeda dengan generasi siswa sebelumnya maka dari itu lah diperlukan sebuah kemampuan baru yang harus diajarkan kepada mahasiswa semester 5 untuk 
melengkapi skillnya guna memperkuat kemampuannya mahasiswa sebagai calon guru sekolah dasar.

Hal yang baru telah menunggu para calon guru $\mathrm{SD}$, tantangan baru terhadap kurikulum yang baru yaitu kurikulum 2013, di mana calon guru ataupun guru harus memiliki kreativitas untuk melakukan pengembangan terhadap model pembelajaran, maupun strategi dalam manajemen kelas di Sekolah Dasar. Seluruh elemen pembelajaran harus dilakukan sebuah validasi agar sesuai dengan perkembangan kurikulum yang tengah mengalami perubahan. Calon guru harus memiliki sebuah skill untuk memadukan sebuah pembelajaran PKn agar pembelajaran di kelas menjadi semakin variatif dan lebih memberikan sebuah pengalaman belajar kepada siswa. Pengembangan terhadap rencana pembelajaran dan Silabus yang ada harus diupayakan berbasis pada karakter, agar tidak hanya kognitif saja yang akan dilakukan treatment, namun domain afektif juga merupakan sebuah hal yang penting dan juga harus 
dipertimbangkan mengingat pola pembangunan 
pendidikan di Indonesia adalah berbasis pembentukan generasi bangsa yang memiliki karakter rasionalisme, nasionalisme, religionisme dan berbasis kearifan lokal.

Profesor Warsono salah satu dosen saya di pascasarjana pernah mengatakan bahwa PKN adalah sebuah mata pelajaran yang harus terus dikaji yang dilakukan sebuah pengembangan yang lebih visioner dan revolutioner agar terus eksis seperti mata pelajaran yang lain disatu sisi lainnya guru adalah aset yang sangat utama yang bertugas untuk melakukan pembenahan terhadap masalah pembelajaran serta menganalisis melalui teori pendidikan yang ada sehingga ditemukanlah sebuah permasalahan nyata lalu guru melalui disiplin ilmunya bisa memecahkan permasalahan tersebut serta menciptakan solusi yang aplikatif sehingga muncul sebuah perspektif yang berbeda serta paradigma baru dalam melakukan pembelajaran PKn pada tingkat sekolah dasar khusus nya di level SD kelas Awal. Sehingga didalam buku ini nantinya berisi sebuah 
pengkajian tentang bagaimana melakukan Sebuah upaya 
yang sistematis dan terencana dalam sebuah proses pembelajaran, sampai pada akhirnya PKN menjadi sebuah mata pelajaran yang dapat memberikan sebuah dampak pengiring terhadap aktivitas siswa serta habituasi yang telah di integrasikan di sekolah maupun saat siswa kembali ke rumah masing-masing. Diharapkan ke depan akan banyak guru SD yang dapat melakukan sebuah inovasi dalam menerapkan pembelajaran dan melakukan pengembangan terhadap kajian mata pelajaran PKn di sekolah dasar. Semoga kajian dalam buku ini menjadi sebuah manfaat bagi kita semuanya, dan kami selaku penyusun juga mengharapkan sebuah masukan yang nantinya akan menjadikan bagian ini lebih menarik dan lebih bermanfaat terhadap perkembangan Khazanah ilmu pendidikan Indonesia.

Penulis 


\section{DAFTAR ISI}

KATA PENGANTAR

BAB 1

Hakikat Pengembangan Model Pembelajaran Dan Media Pkn Sd

A. konsep dan Definisi mapel Pkn (Pendidikan

Kewarganegaraan) tingkat SD

B. Definisi Model Pembelajaran

C. Definisi Media Pembelajaran

D. Model-Model Pembelajaran Pkn Di Sd

BAB 2

Strategi Pengembangan Pembelajaran Pendidikan

Kewarganegaraan (Pkn) Sekolah Dasar (Sd) Dalam Pembentukan

Karakter Melalui Hidden Curriculum

A. konsep Paradigma Pembelajaran Pkn Dalam Perspektif Hidden Curriculum

B. Strategi Pembentukan Karakter Melalui Hidden Curriculum

BAB 3

Penyusunan Silabus Dan Rencana Pelaksanaan Pembelajaran, Serta Pengaplikasiaan Dasar Mengajar Dalam Pembelajaran Pkn SD

A. penyusunan Silabus Dan Rpp Pkn Sd Sesuai Kurikulum $\mathrm{K}-13$

B. Tinjauan Umum Rencana Pelaksanaan Pembelajaran (Rpp) Pada K-13 
C. Aplikasi Delapan Keterampilan Dasar Belajar Mengajar Dalam Simulasi Pembelajaran Pkn Sd 
BAB 4

Langkah - Langkah Pemilihan Dan Penggunaan Metode Dan Media Pembelajaran Pkn SD
A. Tinjauan Umum Metode Pembelajaran Pada Pkn di SD 46
B. Tinjauan Umum Media Pembelajaran Pada Pkn SD

BAB 5

Pengembangan Lks Pkn / Worksheet Yang Berbasis Aktivitas Yang Mengandung

Pengalaman Belajar Yang Bermakna

A. Karakteristik LKS pada level pembelajaran SD 60

B. Penyesuaian Lks Sesuai Dengan Karakter Siswa 62

C. analisis Lks / Worksheet Pkn Berbasis Aktivitas 65

D. analisis Lks / Worksheet Pkn Berbasis Pengalaman Belajar Bermakna

E. aplikasi Pengembangan bahan Ajar PKn di SD

F. deskripsi Implikasi Lembar Kerja Siswa / Dalam Pembelajaran PKn di SD

BAB 6

Perancangan Program Kegiatan Siswa Di Sekolah Yang Berbasis Aktivitas Yang Mengandung Pengalaman Belajar Yang Bermakna Guna Menciptakan Perilaku Berkarakter
A. Konsep Pendidikan Karakter
B. Deskripsi Pendidikan Karakter Di Sekolah
C. Peran Strategis Kegiatan Ekstrakulikuler Sebagai Pembentuk Karakter
D. Deskripsi Contoh Program Sekolah di level SD 


\section{BAB 7}

Perancangan Sebuah Pembelajaran Berbasis Outdoor Learning Pkn Sd Kelas Awal Yang Inovatif Dan Berkarakter

A. deskripsi Hakekat Nilai Karakter 103

B. Pencapaian Nilai Karakter Pada Outdoor Learning 106

C. deskripsi Langkah - Langkah Metode Outdoor Learning 111

D. deskripsi Manfaat Outdoor Learning

BAB 8

Pengembangan Pembelajaran Pkn Sd Kelas 1,2,3 (Kelas Rendah) Melalui Pendekatan Induktif/ Deduktif Dan Ekspository

A. Tinjauan Umum Tentang Pendekatan Induktif

B. Tinjauan Umum Tentang Pendekatan Deduktif

C. Tinjauan Umum Tentang Pendekatan Ekspository

BAB 9

Pengembangan Pembelajaran Pkn Di SD "Perencanaan Sebuah

Pembelajaran Berbasis E-Learning Pkn Sd Kelas Tinggi 4,5,6

Yang Inovatife Dan Berkarakter"

A. Tinjauan Umum Tentang E-Learning 144

B. Pembelajaran Pkn Kelas Tinggi Berbasis E-Learning 146

C. Pelaksanaan Pembelajaran Berbasis E Learning 154

D. Kendala-Kendala Penerapan E-Learning Education 155

E. Upaya Yang Dilakukan Untuk Mengatasi Kendala-Kendala Pembelajaran Berbasis E Learning 156

BAB 10

Pengembangan Model Penilaian Pkn SD (Teknik Tes Dan Non-Tes Serta Aspek Kognitif Dan Non-Kognitif)

A. Pengertian Penilaian Asesment Dalam Pembelajaran 158 
B. Pengembangan Alat Penilaian Dalam Bentuk Tes Dan Non-Tes 159

C. Pengembangan Alat Penilaian Kognitif Dan Non-Kognitif 163

Daftar Pustaka 


\section{BATANG TUBUH \& CP MK}

BAB 1

Hakikat Pengembangan Model Pembelajaran Dan Media Pkn Sd

CP-MK Capaian Pembelajaran Mata Kuliah :
A. Mahasiswa dapat memahami konsep dan Definisi mapel Pkn (Pendidikan Kewarganegaraan) tingkat SD
B. Mahasiswa dapat mendeskripsikan Definisi Model Pembelajaran
C. Mahasiswa dapat mendeskripsikan Definisi Media Pembelajaran
D. Mahasiswa dapat menganalisis Model-Model Pembelajaran Pkn Di Sd

BAB 2

Strategi Pengembangan Pembelajaran Pendidikan Kewarganegaraan (Pkn)Pada Sekolah Dasar (Sd) Dalam Pembentukan KarakterMelalui Hidden Curriculum

CP-MK Capaian Pembelajaran Mata Kuliah :

A. Mahasiswa dapat memahami konsep Paradigma Pembelajaran Pkn Dalam Perspektif Hidden Curriculum

B. Mahasiswa dapat mendeskripsikan Strategi Pembentukan Karakter Melalui Hidden Curriculum

BAB 3

Penyusunan Silabus Dan Rencana Pelaksanaan

Pembelajaran, Serta Pengaplikasiaan Dasar Mengajar Dalam

Pembelajaran Pkn SD

CP-MK Capaian Pembelajaran Mata Kuliah :

A. Mahasiswa dapat memahami cara penyusunan Silabus Dan Rpp Pkn Sd Sesuai Kurikulum K-13 
B. Mahasiswa dapat mendeskripsikan Tinjauan Umum Rencana Pelaksanaan Pembelajaran (Rpp) Pada K-13

C. Mahasiswa dapat Mengaplikasikan Delapan Keterampilan Dasar Belajar Mengajar Dalam Simulasi Pembelajaran Pkn Sd 


\section{BAB 4}

Langkah - Langkah Pemilihan Dan Penggunaan

Metode Dan Media Pembelajaran Pkn SD

CP-MK Capaian Pembelajaran Mata Kuliah :

A. Mahasiswa dapat memahami Tinjauan Umum Metode Pembelajaran Pada Pkn di SD

B. Mahasiswa dapat mendeskripsikan Tinjauan Umum Media Pembelajaran Pada Pkn SD

\section{BAB 5}

Pengembangan Lks Pkn / Worksheet Yang Berbasis Aktivitas Yang Mengandung Pengalaman Belajar Yang Bermakna

CP-MK Capaian Pembelajaran Mata Kuliah :

A. Mahasiswa dapat memahami Karakteristik LKS pada level pembelajaran SD

B. Mahasiswa dapat mendeskripsikan Penyesuaian Lks Sesuai Dengan Karakter Siswa

C. Mahasiswa dapat menganalisis Lks / Worksheet Pkn Berbasis Aktivitas

D. Mahasiswa dapat menganalisis Lks / Worksheet Pkn Berbasis

Pengalaman Belajar Bermakna

E. Mahasiswa dapat mengaplikasikan Pengembanganbahan Ajar PKn di SD

F. Mahasiswa dapat mendeskripsikan Implikasi Lembar Kerja

Siswa / Dalam Pembelajaran

Perancangan Program Kegiatan Siswa Di Sekolah Yang Berbasis Aktivitas Yang

Mengandung Pengalaman Belajar Yang Bermakna Guna

Menciptakan Perilaku Berkarakter

CP-MK Capaian Pembelajaran Mata Kuliah :
A. Mahasiswa dapat memahami Konsep Pendidikan Karakter
B. Mahasiswa dapat mendeskripsikan Pendidikan Karakter Di Sekolah 
C. Mahasiswa dapat menganalisis Peran Strategis Kegiatan Ekstrakulikuler Sebagai Pembentuk Karakter

D. Mahasiswa dapat mendeskripsikan Contoh Program Sekolah di level SD 


\section{BAB 7}

Perancangan Sebuah Pembelajaran Berbasis Outdoor Learning Pkn Sd Kelas Awal Yang Inovatif Dan Berkarakter

CP-MK Capaian Pembelajaran Mata Kuliah :

A. Mahasiswa dapat memahami Hakekat Outdoor Learning

B. Mahasiswa dapat mendeskripsikan Hakekat Nilai Karakter

C. Mahasiswa dapat menganalisis Pencapaian Nilai Karakter Pada Outdoor Learning

D. Mahasiswa dapat mendeskripsikan Langkah - Langkah Metode Outdoor Learning

E. Mahasiswa dapat mendeskripsikan Manfaat Outdoor Learning

BAB 8

Pengembangan Pembelajaran Pkn Sd Kelas 1,2,3 (Kelas Rendah)

Melalui Pendekatan Induktif/ Deduktif Dan Ekspository

CP-MK Capaian Pembelajaran Mata Kuliah :

A. Mahasiswa dapat memahami Tinjauan Umum Tentang Pendekatan Induktif

B. Mahasiswa dapat mendeskripsikan Tinjauan Umum Tentang Pendekatan Deduktif

C. Mahasiswa dapat mendeskripsikan Tinjauan Umum Tentang Pendekatan Ekspository 


\begin{abstract}
BAB 9
Pengembangan Pembelajaran Pkn Di Sd

"Perencanaan Sebuah Pembelajaran Berbasis

E-Learning Pkn Sd Kelas Tinggi 4,5,6 Yang

Inovatife Dan Berkarakter"
\end{abstract}

Capaian Pembelajaran (CP) :

A. Mahasiswa dapat memahami Tinjauan Umum Tentang E-Learning

B. Mahasiswa dapat mendeskripsikan Pembelajaran Pkn Kelas Tinggi

Berbasis E- Learning

C. Mahasiswa dapat mendeskripsikan Pelaksanaan Pembelajaran

Berbasis E Learning

D. Mahasiswa dapat menganalisis Kendala-Kendala Penerapan

E-Learning Education

E. Mahasiswa dapat menganalisis Upaya Yang Dilakukan Untuk Mengatasi Kendala-Kendala

\author{
BAB 10 \\ Pengembangan Model Penilaian Pkn Sd \\ (Teknik Tes Dan Non-Tes Serta Aspek Kognitif Dan
}

Non-Kognitif) CP-MK Capaian Pembelajaran Mata Kuliah :

A. Mahasiswa dapat memahami Pengertian Penilaian Asesment Dalam Pembelajaran

B. Mahasiswa dapat mendeskripsikan Pengembangan Alat Penilaian Dalam Bentuk Tes Dan Non-Tes

C. Mahasiswa dapat mendeskripsikan Pengembangan Alat Penilaian Kognitif Dan Non-Kognitif 


\section{KATA PENGANTAR}

Alhamdulillahirabbil'aalamin, Kalimat ini lah ungkapan puji syukur kehadirat Allah SWT Yang Maha pengasih dan penyayang. Kiranya tanpa karunia-nya, mustahil naskah buku "Pendidikan PKn SD kelas Awal" ini dapat terselesaikan tepat waktu. Latar belakang dari penyusunan buku ini adalah sebuah pemikiran bahwa PKn adalah sebuah mata pelajaran yang kelak akan menjadi sebuah pionir utama dalam upaya menerapkan sebuah perilaku berkarakter kepada siswa SD sehingga para guru maupun calon guru diharapkan memiliki sebuah kemampuan dalam melakukan sebuah inovasi dan strategi guna mengembangkan pembelajaran pada mata pelajaran PKn di sekolah dasar khusus nya di level SD kelas Awal. Pada saat ini kita sudah memasuki era digital di mana siswa sudah memiliki sebuah dunia yang berbeda dengan generasi siswa sebelumnya maka dari itu lah diperlukan sebuah kemampuan baru yang harus diajarkan kepada mahasiswa semester 5 untuk 
melengkapi skillnya guna memperkuat kemampuannya mahasiswa sebagai calon guru sekolah dasar.

Hal yang baru telah menunggu para calon guru $\mathrm{SD}$, tantangan baru terhadap kurikulum yang baru yaitu kurikulum 2013, di mana calon guru ataupun guru harus memiliki kreativitas untuk melakukan pengembangan terhadap model pembelajaran, maupun strategi dalam manajemen kelas di Sekolah Dasar. Seluruh elemen pembelajaran harus dilakukan sebuah validasi agar sesuai dengan perkembangan kurikulum yang tengah mengalami perubahan. Calon guru harus memiliki sebuah skill untuk memadukan sebuah pembelajaran PKn agar pembelajaran di kelas menjadi semakin variatif dan lebih memberikan sebuah pengalaman belajar kepada siswa. Pengembangan terhadap rencana pembelajaran dan Silabus yang ada harus diupayakan berbasis pada karakter, agar tidak hanya kognitif saja yang akan dilakukan treatment, namun domain afektif juga merupakan sebuah hal yang penting dan juga harus 
dipertimbangkan mengingat pola pembangunan 
pendidikan di Indonesia adalah berbasis pembentukan generasi bangsa yang memiliki karakter rasionalisme, nasionalisme, religionisme dan berbasis kearifan lokal.

Profesor Warsono salah satu dosen saya di pascasarjana pernah mengatakan bahwa PKN adalah sebuah mata pelajaran yang harus terus dikaji yang dilakukan sebuah pengembangan yang lebih visioner dan revolutioner agar terus eksis seperti mata pelajaran yang lain disatu sisi lainnya guru adalah aset yang sangat utama yang bertugas untuk melakukan pembenahan terhadap masalah pembelajaran serta menganalisis melalui teori pendidikan yang ada sehingga ditemukanlah sebuah permasalahan nyata lalu guru melalui disiplin ilmunya bisa memecahkan permasalahan tersebut serta menciptakan solusi yang aplikatif sehingga muncul sebuah perspektif yang berbeda serta paradigma baru dalam melakukan pembelajaran PKn pada tingkat sekolah dasar khusus nya di level SD kelas Awal. Sehingga didalam buku ini nantinya berisi sebuah 
pengkajian tentang bagaimana melakukan Sebuah upaya 
yang sistematis dan terencana dalam sebuah proses pembelajaran, sampai pada akhirnya PKN menjadi sebuah mata pelajaran yang dapat memberikan sebuah dampak pengiring terhadap aktivitas siswa serta habituasi yang telah di integrasikan di sekolah maupun saat siswa kembali ke rumah masing-masing. Diharapkan ke depan akan banyak guru SD yang dapat melakukan sebuah inovasi dalam menerapkan pembelajaran dan melakukan pengembangan terhadap kajian mata pelajaran PKn di sekolah dasar. Semoga kajian dalam buku ini menjadi sebuah manfaat bagi kita semuanya, dan kami selaku penyusun juga mengharapkan sebuah masukan yang nantinya akan menjadikan bagian ini lebih menarik dan lebih bermanfaat terhadap perkembangan Khazanah ilmu pendidikan Indonesia.

Penulis 




\section{DAFTAR ISI}

KATA PENGANTAR

\section{BAB 1}

HakikatPengembangan Model Pembelajaran Dan Media PknSd

A. konsep dan Definisi mapel Pkn (Pendidikan Kewarganegaraan) tingkat SD .. 1 B. Definisi Model Pembelajaran 4

C. Definisi Media Pembelajaran

D. Model-Model Pembelajaran Pkn Di Sd

\section{BAB 2}

Strategi Pengembangan Pembelajaran Pendidikan Kewarganegaraan (Pkn) Sekolah Dasar (Sd) Dalam Pembentukan KarakterMelalui Hidden Curriculum

A. konsep Paradigma Pembelajaran Pkn Dalam Perspektif Hidden Curriculum 18

B. Strategi Pembentukan Karakter Melalui Hidden Curriculum

\section{BAB 3}

PenyusunanSilabus Dan RencanaPelaksanaanPembelajaran, Serta PengaplikasiaanDasarMengajarDalamPembelajaranPkn SD
A. penyusunan Silabus Dan Rpp Pkn Sd Sesuai Kurikulum K-13
B. Tinjauan Umum Rencana Pelaksanaan Pembelajaran (Rpp) Pada K-13
34
C. Aplikasi Delapan Keterampilan Dasar Belajar Mengajar Dalam Simulasi Pembelajaran Pkn Sd

\section{BAB 4}

Langkah - LangkahPemilihan Dan PenggunaanMetode Dan Media PembelajaranPkn SD 
A. Tinjauan Umum Metode Pembelajaran Pada Pkn di SD 46

B. Tinjauan Umum Media Pembelajaran Pada Pkn SD 


\section{BAB 5}

Pengembangan Lks Pkn / Worksheet Yang BerbasisAktivitas Yang Mengandung PengalamanBelajar Yang Bermakna

A. KarakteristikLKS pada level pembelajaran SD

B. Penyesuaian Lks Sesuai Dengan KarakterSiswa

C. analisis Lks / Worksheet Pkn BerbasisAktivitas

D. analisis Lks / Worksheet Pkn Berbasis Pengalaman BelajarBermakna

E. aplikasi Pengembanganbahan Ajar PKn di SD

F. deskripsi Implikasi Lembar Kerja Siswa / DalamPembelajaran PKn di SD 71

\section{BAB 6}

Perancangan Program KegiatanSiswa Di Sekolah Yang BerbasisAktivitas Yang MengandungPengalamanBelajar Yang

BermaknaGunaMenciptakanPerilakuBerkarakter
A. Konsep Pendidikan Karakter
73
B. DeskripsiPendidikan Karakter Di Sekolah
C. Peran Strategis Kegiatan Ekstrakulikuler Sebagai Pembentuk Karakter 90
D. DeskripsiContoh Program Sekolah di level SD

\section{BAB 7}

PerancanganSebuahPembelajaranBerbasis Outdoor Learning PknSdKelasAwal Yang Inovatif Dan Berkarakter
A. deskripsi Hakekat Nilai Karakter
B. Pencapaian Nilai Karakter Pada Outdoor Learning
C. deskripsi Langkah - Langkah Metode Outdoor Learning
D. deskripsi Manfaat Outdoor Learning

\section{BAB 8}

PengembanganPembelajaranPknSdKelas 1,2,3 (KelasRendah) MelaluiPendekatanInduktif/ Deduktif Dan Ekspository 
B. Tinjauan Umum Tentang Pendekatan Deduktif

C. Tinjauan Umum Tentang Pendekatan Ekspository

BAB 9

PengembanganPembelajaranPkn Di SD

"PerencanaanSebuahPembelajaranBerbasis E-Learning PknSdKelas Tinggi 4,5,6 Yang Inovatife Dan Berkarakter"

A. Tinjauan Umum Tentang E-Learning

B. Pembelajaran Pkn Kelas Tinggi Berbasis E-Learning

C. Pelaksanaan Pembelajaran Berbasis E Learning

D. Kendala-Kendala Penerapan E-Learning Education

E. Upaya Yang Dilakukan Untuk Mengatasi Kendala-Kendala Pembelajaran Berbasis E Learning

\section{BAB 10}

PengembanganModel PenilaianPkn SD (TeknikTes Dan Non-Tes Serta AspekKognitif Dan Non-Kognitif)

A. Pengertian Penilaian Asesment Dalam Pembelajaran

B. Pengembangan Alat Penilaian Dalam Bentuk Tes Dan Non-Tes 159

C. Pengembangan Alat Penilaian Kognitif Dan Non-Kognitif 


\section{BAB 1}

Hakikat Pengembangan Model Pembelajaran dan

Media PKn SD

CP-MK Capaian Pembelajaran Mata Kuliah :

A. Mahasiswa dapat memahami konsep dan Definisi mapel Pkn (Pendidikan Kewarganegaraan) tingkat SD

B. Mahasiswa dapat mendeskripsikan Definisi Model Pembelajaran

C. Mahasiswa dapat mendeskripsikan Definisi Media Pembelajaran

D. Mahasiswa dapat menganalisis Model-Model Pembelajaran Pkn Di Sd

\section{A. Definisi PKn (Pendidikan Kewarganegaraan)}

Sebuah pembelajaran yang dilakukan di sekolah formal tentunya memiliki tujuannya masing-masing. Tujuan ini merupakan misi sasaran yang ingin dicapai dalam sebuah pembelajaran di masa yang akan datang. Tujuan dari sebuah mata pelajaran juga dapat berarti langkah pertama dalam proses mencapai sebuah kesuksesan sebuah mata pelajaran. Tujuan dari setiap mata pelajaran ini tentunya memiliki kegunaan dan fungsi bagi peserta didik. Dimana tujuan dan fungsi ini memberikan pengetahuan dasar yang wajib ditempuh dan diterima oleh peserta didik, terutama peserta didik yang duduk di bangku sekolah dasar. Pengetahuan dasar yang mereka dapatkan ini 
nantinya akan lebih diperdalam dan ditegaskan lagi di bangku sekolah menengah pertama. Oleh karena itu pengetahuan dasar yang mereka dapatkan akan mendasari pembelajaran mereka di jenjang 
yang lebih tinggi. Membahas tentang tujuan sebuah pembelajaran, misalnya pembelajaran Bahasa Indonesia yang bertujuan untuk mengajarkan dan mengenalkan kepada peserta didik tentang berbahasa Indonesia yang baik dan benar sesuai aturan yang berlaku. Begitu pula dengan tujuan Pendidikan Kewarganegaraan,

\begin{abstract}
"Menurut Fathurrohman (2012) tujuan pendidikan kewarganegaraan adalah untuk mengembangkan kemampuan peserta didik agar dapat tumbuh menjadi warga negara yang baik"
\end{abstract}

Tujuan dasar untuk menjadikan peserta didik menjadi warga negara yang baik perlu digaris bawahi, karena memiliki arti yang luas. Apabila pembelajaran ini ditujukan untuk anak sekolah dasar tentunya warga negara yang baik adalah yang menaati peraturan, tertib, demokrasi dalam mufakat, pengenalan dasar terhadap sistem pemerintahan disekitar mereka, dan lain sebagainya. Dalam pembelajaran ini peserta didik mulai di perkenalkan tentang sistem pemerintahan dan aturan-aturan yang berlaku dalam masyarakat. Mereka juga akan ditanamkan jiwa cinta tanah air dan patriotisme. Lalu mereka akan diajarkan sifat lebih mementingkan urusan masyarakat dan negara ketimbang urusan pribadi mereka sendiri. Setelah mengetahui bahwa tujuan dari Pembelajaran PKn adalah untuk mengembangkan kemampuan peserta didik agar dapat tumbuh menjadi warga negara yang 
baik. Dalam pembelajaran ini juga mengarahkan mereka untuk memiliki sikap yang disiplin, sopan, santun, jujur dan bertanggung 
jawab. Lalu apa yang dimaksud dengan pembelajaran PKn itu sendiri atau apa definisi dari pembelajaran Pkn? Seorang ahli mengemukakan,

"Pendidikan Kewarganegaraan adalah pendidikan yang mengkaji dan membahas tentang pemerintahan, konstitusi, lembaga-lembaga demokrasi, rule of law, HAM, hak dan kewajiban warga negara serta proses demokrasi (Azyumardi Azra 2002)"

Pengkajian dan pembahasan tentang Pendidikan Kewarganegaraan ini tentunya dalam porsi yang tidak terlalu berat dan dalam, karena ditujukan untuk peserta didik sekolah dasar. Pembahasan-pembahasan yang diangkat umumnya hanya untuk pengenalan saja. Pembahasan yang diangkat tentang pemerintahan misalnya, hanya dikenalkan sebatas tata urutan pemerintahan dari yang tertinggi hingga terendah. Misalnya lagi tentang pembahasan hak dan kewajiban, hanya diajarkan sebatas bagaimana hak dan kewajiban mereka sebagai seorang siswa, anak, dan warga negara yang baik. Begitu pula dengan pembahasan tentang konstitusi, lembaga-lembaga demokrasi, rule of law, HAM dan lainnya hanya dibahas secara singkat dan tidak terlalu mendalam. Pendidikkan Kewarganegaran juga memiliki kompetensi-kompetensi yang ingin dibentuk dalam sikap peserta didik.

"BSNP (Badan Standar Nasional Pendidikan) menetapkan beberapa kompetensi-kompetensi 
yang sesuai dengan siswa, dijelaskan sebagai berikut: 
1. Berpikir secara kreatif, rasional dan kritis dalam menanggapi permasalahan kewarganegaraan.

2. Berpartisipasi secara bertanggung jawab, bermutu dan bertindak secara cerdas dalam kegiatan bermasyarakat, berbangsa, dan bernegara.

3. Berfikir dengan berkembang secara demokratis namun positif untuk membentuk diri sendiri berdasarkan pada karakter masyarakat Indonesia agar dapat hidup berdampingan dan beriringan dengan negara lain.

4. Berinteraksi dengan negara-negara lain dalam peraturan dunia secara langsung maupun tidak langsung dengan memanfaatkan TIK (Teknologi Informasi dan Komunikasi)".

\section{B. Definisi Model Pembelajaran}

Dalam proses belajar mengajar tentunya pendidik memerlukan banyak persiapan dan kesiapan, baik secara fisik maupun mental. Persiapan secara fisik misalnya sarana dan prasarana yang ada, apakah telah memenuhi standar yang tersedia atau belum. Begitu pula dengan kesiapan mental sang pendidik, dimana pendidik dituntut harus menguasai materi yang akan diajarkan kepada peserta didik. Setiap peserta didik memiliki ciri khas sendiri dalam mengajar, memiliki karakteristik yang berbeda dengan pendidik yang lain. Biasanya pendidik memiliki 
modelnya sendiri dalam menjelaskan materi yang diajarkannya. Pemilihan model pembelajaran sepenuhnya berada ditangan pendidik, bagaimana model pembelajaran 
yang sesuai dan tepat dengan materi yang akan diajarkan. Pendidik harus pandai melihat apakah model pembelajaran yang digunakannya dapat mencapai tujuan dari pemberlajaran yang akan berlangsung nantinya. Lalu apa arti sesungguhnya dari model pembelajaran?

"Model pembelajaran merupakan kerangka konseptual yang mendeskripsikan dan melukiskan prosedur yang sistematik dalam mengorganisasikan pengalaman belajar dan pembelajaran untuk mencapai tujuan belajar tertentu, dan berfungsi sebagai pedoman bagi perencanaan pembelajaran bagi guru dalam melaksanakan aktivitas pembelajaran, oleh Mohammad Syarif Sumantri (2015)".

"Model pembelajaran adalah suatu perencanaan atau suatu pola yang digunakan sebagai pedoman dalam merencanakan pembelajaran di kelas. Model pembelajaran mengacu pada pendekatan pembelajaran yang digunakan, termasuk di dalamnya tujuan-tujuan pembelajaran, tahap-tahap dalam kegiatan pembelajaran, lingkungan pembelajaran, dan pengelolaan kelas (Trianto, 2012)".

Model pembelajaran umumnya disusun dari beberapa teori atau prinsip pengetahuan. Para ahli 
menyusun model pembelajaran menurut prinsip-prinsip pembelajaran, teori- teori sosiologis, psikologis, analisis sistem, atau teori-teori lain yang mendukung suatu pengembangan model 
pembelajaran tersebut. Joyce dan Weil berpendapat bahwa model pembelajaran adalas suatu pola atau rencana yang dapat digunakan untuk merancang bahan-bahan pembelajaran di kelas, membentuk kurikulum (rencana pembelajaran jangka panjang), membimbing terlaksananya pembelajaran di kelas dan lain sebagainya. Adanya model pembelajaran ini tentunya untuk membantu guru maupun siswa dalam pelaksanaan pembelajaran yang berlangsung. Guru boleh memilih model pembelajaran yang efisien dan sesuai dengan mata pelajaran yang akan diajarkan, tentunya model pembelajaran tersebut harus dapat mencapai tujuan dari pembelajaran dari mata pelajaran tersebut. Dengan adanya model pembelajaran yang bervariasi membuat pembelajaran menjadi lebih menarik dan tidak terkesan monoton. Dengan begitu siswa akan merasa senang dalam mengikuti pembelajaran yang berlasung. Dan siswa dapat menyerap pembelajaran yang diajarkan dengan mudah.

\section{Definisi Media Pembelajaran}

"Yusufhadi Miarso (2004) berpendapat bahwa, Media Pembelajaran adalah segala sesuatu yang digunakan untuk menyalurkan pesan serta dapat merangsang pikiran, perasaan, perhatian, dan kemauan, si pelajar sehingga dapat mendorong proses belajar".

"Karti Hari Sukarsih (2002), Media Pembelajaran 
adalah segala sesuatu yang dapat digunakan untuk mencapai tujuan pengajaran, pengaturan media pembelajaran dan perabot kelas harus sedemikian 
rupa sehingga mendukung suasana belajar mengajar".

Media pembelajaran adalah hal penting yang harus di monitor dalam pelaksanaan pembelajaran oleh guru, karena karakter siswa yang sangat beragam, ada siswa yang tipe belajarnya kinestetis, visual dan auditif. Keberagaman karakter siswa ini dapat diatasi apabila guru menggunakan bermacam media pembelajaran atau multimedia. Kedudukan media biasanya berjalan sejajar dengan model dan metode pembelajaran yang digunakan, karena dalam suatu proses pembelajaran biasanya media apa yang bisa diadaptasikan dan dintegrasikan dengan kondisi yang akan dihadapi. Media dalam dunia pendidikan menjadi sangat strategis dalam ikut menentukan keberhasilan proses belajar mengajar, sebab keberadaannya secara langsung dapat memberikan dampak tersendiri bagi peserta didik. Pengaturan media pembelajaran harus sedemikian rupa sehingga dapat mendukung suasana belajar mengajar. Dalam pengertian ini guru, buku teks, dan lingkungan sekolah merupakan media. Secara lebih khusus, pengertian media dalam proses belajar mengajar cenderung diartikan alat-alat grafis, photografis, atau elektronis untuk menyusun, memproses dan menangkap informasi visual danverbal. Dengan demikian dapat disimpulkan secara garis besar, apabila mendengar kata media pembelajaran yaitu adalah alat bantu guru alat bantu 
guru dalam mengajar serta sarana pembawa pesan belajar. Sebagai penyaji dan penyalur pesan, media belajar dalam hal-hal tertentu, bisa mewakili guru menyajikan informasi belajar kepada 
siswa.

\section{Model-model Pembelajaran PKn di SD}

"Fathurrohman (2012), Model-model pembelajaran yang cocok di PKn SD :

1. Model Pembelajaran Kontekstual

(Contextual Teaching and Learning)

2. Model Pembelaran Kooperatif

3. Model Pembelajaran Berbasis

Masalah (Problem Based Intoduction)

4. Model Pembelajaran Berbasis Fortofolio"

1. Model Pembelajaran Kontekstual (Contextual Teaching and Learning)

Model pembelajaran ini menuntut guru agar mampu mengaitkan antara materi yang diajarkan dengan situasi dunia nyata siswa. Tidak berhenti disitu, guru juga diharapkan mampu mendorong siswa membuat hubungan antara pengetahuan yang dimilikinya dengan penerapannya dalam kehidupan mereka (dalam keluarga, bermasyarakat, bersoial). Model pembelajaran ini memegang prinsip learning to do yaitu memberikan kesempatan pada siswa untuk melakukan, mencoba dan mengalami sendiri terkait pembelajaran yang berlansung untuk menambah pengetahuan yang dimiliki. Dengan begitu model pembelajaran CTL ini dapat membuat pembelajaran menjadi lebih prodiktif dan bermakna. 
Dimana nantinya dapat melatih siswa agar dapat berpikir kritis dan terampil dalam memproses pengetahuan agar 
dapat menemukan dan menciptakan sesuatu yang bermanfaat bagi dirinya dan orang lain. Tujuan dari model pembelajaran ini adalah untuk memotivasi siswa unutuk memahami makna materi pelajaran yang dipelajarinya dengan mengaitkan materi tersebut dengan konteks kehidupan sehari-hari mereka, sehingga siswa memeiliki pengetahuan atau keterampilan yang secara refleksi dapat diterapkan dari permasalahan lainnya. Dan agar dalam belajar siswa tidak hanya monoton menghafal namun perlu dengan adanya pemahaman.

Secara garis besar langkah-langkah penerapan CTL dalam kelas sebagai berikut:

a. Mengembangkan pemikiran siswa bahwa belajar akan lebih bermakna dengan cara bekerja sendiri dan menemukan sendiri keterampilan barunya.

b. Melaksanakan sejauh mungkin kegiatan inkuiri untuk semua topik.

c. Mengembangkan sifat ingin tahu siswa dengan memberi stimulus agar siswa bertanya.

d. Menciptakan masyarakat belajar (belajar dalam kelompok-kelompok).

e. Menghadirkan model sebagai contoh pembelajaran.

f. Melakukan refleksi di akhir pertemuan.

g. Melakukan penilaian yang sebenarnya dengan berbagai cara. 
Dalam Pembelajaran yang menggunakan model pembelajaran kontekstual ada beberapa komponen 
yang dilibatkan dalam pembelajaran, komponen tersebut adalah sebagai berikut :

a. Kontrukstivisme (siswa mampu membangun pengetahuan berdasarkan pengalaman yang dialami dan diamati).

b. Bertanya (siswa diharapkan mampu menumbuhkan rasa ingin tahu sehingga akan menjadikan siswa selalu bertanya terhadap hal- hal yang baru).

c. Inkuiri (siswa dilatih untuk menemukan konsep yang dipelajari melalui proses belajar yang sistematis).

d. Masyarakat belajar (siswa diharapkan mampu bekerjasama atau bertukar pikiran dengan orang lain yang tidak terbatas dalam proses pembelajaran).

e. Pemodelan/Modelling (memberikan pengalaman yang lebih nyata atau konkret kepada siswa. Melalui pemodelan ini akan menghindarkan siswa dari pengetahuan yang bersifat abstrak dan teoritis).

f. Refleksi (refleksi yang diperlukan untuk mengevaluasi pengetahuan yang diperoleh siswa melalui pengalaman yang ia dapatkan).

g. Penilaian sebenarnya/authentic assessment (mengetahui perkembangan belajar siswa dan dapat mengetahui 
apakah pengalaman belajar siswa dapat memberikan dampak postif atau negatif). 
2. Model Pembelajaran Kooperatif

Pada hakikatnya model pembelajaran Kooperatif sama dengan kerja kelompok, menggunakanstrategi pembelajaran yang melibatkan partisipasi siwa dalam satu kelopok kecil untuk saling berinteraksi. Tentunya dalam pembelajaran ini nantinya akan menciptakan yang lebih luas, yaitu komunikasi dan interaksi antar guru dengan siswa, siswa dengan siswa, dan siswa dengan guru. Komunikasai dan interaksi ini biasa disebut multi way traffic comunication. Model pembelajara Kooperatif menekankan pada peserta didik tentang kerjasama dalam kelompok. Rangkaian belajar yang dilakukan oleh siswa dalam kelompok-kelompok ini tentunya untuk mencapai tujuan pembelajaran yang telah dirumuskan.

3. Model Pembelajaran Berbasis Masalah (Problem Based Intoduction)

4. Model Pembelajaran Berbasis Fortofolio 


\section{BAB 2}

\section{Strategi Pengembangan Pembelajaran \\ Pendidikan Kewarganegaraan (Pkn)Pada \\ Sekolah Dasar (Sd) Dalam Pembentukan \\ KarakterMelalui Hidden Curriculum}

\section{CP-MK Capaian Pembelajaran Mata Kuliah :}

A. Mahasiswa dapat memahami konsep Paradigma Pembelajaran Pkn Dalam Perspektif Hidden Curriculum

B. Mahasiswa dapat mendeskripsikan Strategi Pembentukan Karakter Melalui Hidden Curriculum

Berbicara mengenai Pendidikan Kewarganegaraan (PKn), tentu tidak lepas dari tiga unsur dasar yang menjadi pokok di dalam kegiatan pembelajaran Pendidikan Kewarganegaraan (PKn) yang meliputi konsep civics, civics education dan citizenship education. Secara umum, konsep civics dipandang sebagai materi pemerintahan atau dapat dikatakan ilmu kewarganegaraan yang di dalamnya mempelajari hubungan antarindividu serta antar individu dengan negara. Merujuk pada konsep Pendidikan Kewarganegaraan (PKn) yang kedua, yakni civics education yang dapat diartikan bahwa pengembangan perilaku setiap individu dapat dilaksanakan melalui kegiatan pembelajaran baik pada matapelajaran, kegiatan peserta didik, kegiatan 
administrasi serta pembinaan yang sistematis dalam suatu proses pendidikan. Sedangkan konsep Pendidikan Kewarganegaraan (PKn) yang ketiga, yakni citizenship education. 
Citizenship education lebih cenderung digunakan dalam visi yang lebih luas untuk menunjukkan "instructional effects" dan "nurturant effects" dari keseluruhan proses pendidikan terhadap pembentukan karakter individu sebagai warga negara yang cerdas dan baik. (John J. Cogan dan Ray Derricot: 1998)

Dapat disimpulkan bahwa citizenship education merupakan keseluruhan proses pendidikan yang berbasis karakter untuk mewujudkan warga negara yang cerdas dan baik yang ditunjukkan melalui instructional effects.Tujuan dari Pendidikan Kewarganegaraan (PKn) sendiri lebih menekankan pada berbagai kemampuan dan karakter yang harus dimiliki oleh peserta didik. Pertama, peserta didik mampu berfikir secara kritis, kreatif serta rasional dalam menanggapi isu kewarganegaraan. Kedua, peserta didik diharapkan mampu mengembangkan diri, membawa serta melibatkan diri secara aktif dan bertanggung jawab baik di lingkungan keluarga, lingkungan sekolah maupun lingkungan masyarakat. Ketiga, peserta didik dapat bertindak secara cerdas di setiap kegiatan yang dilakukan baik bermasyarakat, berbangsa dan bernegara serta anti korupsi. Keempat, peserta didik dapat membentuk diri berdasarkan karakter-karakter yang sesuai dengan masyarakat Indonesia serta dapat mengembangkan dirinya secara 
positif dan demokratis yang berlandaskan nilai-nilai luhur Pancasila.

Lima macam karakter yang dapat dibangun melalui PKn yaitu karakter individual, karakter privat, karakter 
publik, karakter cerdas dan karakter baik (good character). (Ace Suryadi dan Dasim Budimansyah: 2009).

Apabila diuraikan lebih lanjut, kelima macam karakter yang diharapkan dapat diinternalisasikan ke dalam kehidupan sehari-hari seperti yang telah disebutkan diatas dapat diuraikan kembali seperti pada penjelasan berikut:

1. Karakter individual

Karakter individual dapat dimaknai dan ditumbuhkan sebagai hasil keterpaduan beberapa bagian dalam diri seseorang, yakni olah hati, olah pikir, olah raga serta olah rasa dan karsa.

2. Karakter privat

Kasakter ini dapat tercermin melalui sikap tanggung jawab moral dan disiplin.

3. Karakter publik

Karakter publik dapat tercermin melalui sikap kepedulian, kesopanan, mengindahkan aturan main (rule of law) dan berpikir kritis.

4. Karakter cerdas

Karakter cerdar ditandai melalui sikap perilaku seseorang yang aktif, dinamis, kritis, kreatif, berpikir terbuka dan inovatif.

5. Karakter baik (good character)

Karakter baik (good character) merupakan karakter yang dapat ditumbuhkan sebagai perilaku baik terhadap berbagai pihak, baik terhadap diri sendiri, alam semesta dan Tuhan Yang Maha Esa. 


\section{A. Paradigma Pembelajaran PKn dalam perspektif hidden curriculum}

Pencapaian tujuan Pendidikan Kewarganegaraan (PKn) serta pembentukan karakter yang diharapkan tersebut dapat dilakukan melalui hidden curriculum pada lembaga pendidikan. Istilah kurikulum yang digunakan pada umumnya jika ditinjau kembali dari pelaksanaan serta konsepnya dapat dibedakan menjadi dua jenis, yaitu kurikulum ideal dan kurikulum aktual. Kurikulum ideal mengacu pada pelaksanaan kurikulum yang telah tertuang sebelumnya pada dokumen kurikulum, sedangkan kurikulum aktual merupakan kurikulum yang lebih menitikberatkan pada pengalaman belajar yang akan diperoleh peserta didik selama proses pembelajaran berlangsung dan didalamnya terdapat kurikulum tersembunyi (hidden curriculum) yang dapat kita jumpai.

Hidden curriculum (kurikulum tersembunyi) merupakan sesuatu yang dapat dimanfaatkan oleh guru dalam pencapaian tujuan pembelajaran dimana berbagai kegiatan maupun kejadian yang terlaksana selama proses pembelajaran berlangsung tidak direncanakan keberadaannya. Dapat dikatakan bahwa hidden curriculum (kurikulum tersembunyi) merupakan suatu proses pembelajaran yang tidak direncanakan. Segala sesuatu yang menyangkut serta mengandung pesan moral di dalamnya, baik berupa tingkah laku, sikap dan gaya bicara yang muncul selama proses 
pembelajaran dapat dikatakan sebagai hidden curriculum (kurikulum tersembunyi). 
Terdapat dua makna yang ada di dalam hidden curriculum (kurikulum tersembunyi). Pertama, pencapaian pada hidden curriculum ini dapat dijadikan sebagai bahan pertimbangan bagi guru selama kegiatan pembelajaran agar lebih bermakna, mengingat hidden curriculum (kurikulum tersembunyi) ini termasuk tujuan pembelajaran yang sifatnya tidak tertulis. Kedua, guru juga dapat menggunakan hidden curriculum (kurikulum tersembunyi) ini sebagai tujuan pembelajaran karena pelaksanaannya yang tidak direncanakan sebelumnya.

Hidden curriculum (kurikulum tersembunyi) dapat dilakukan di dalam lembaga pendidikan sebagai bentuk penanaman nilai-nilai karakter positif yang diharapkan mampu diintegrasikan pada kehidupan sehari-hari peserta didik melalui beberapa kegiatan yang berlangsung, diantaranya yaitu yang pertama melalui kegiatan intrakurikuler atau proses belajar mengajar di kelas yang merupakan kegiatan utama pada lembaga pendidikan. Sekolah diberi kebebasan untuk memilih strategi, metode serta teknik-teknik pembelajaran yang digunakan serta pengajaran yang efektif yang disesuaikan dengan katakteristik mata pelajaran, peserta didik, guru dan kondisi nyata sumber daya yang tersedia di sekolah.

Pada strategi pengajaran, cara-cara belajar siswa aktif seperti active learning, cooperative learning dan quantum learning perlu diterapkan. (Rohiat: 2010: 65) 
Selain itu, pelaksanaan hidden curiculum juga dapat dilakukan melalui kegiatan ekstrakurikuler yang merupakan kegiatan yang dilakukan peserta didik diluar jam belajar 
pada kurikulum standar.Pendidikan karakter melalui pelaksanaan hidden curriculum (kurikulum tersembunyi) ini telah dilaksanakan oleh berbagai lembaga pendidikan, salah satunya diantaranya sebagai contoh, yakni dikutip dari jurnal penelitian milik Prawidya Lestari dan Sukanti tahun 2016 yang berjudul "Membangun Karakter Siswa Melalui Kegiatan Intrakurikuler, Ekstrakurikuler dan Hidden Curriculum (di SD Budi Mulia Dua Pandeansari Yogyakarta)" dapat dijelaskan bahwa:

1. Konsep pendidikan karakter di SD Budi Mulia Dua Pandeansari Yogyakarta pada hakikatnya masuk ke dalam hidden curriculum (kurikulum tersembunyi).

2. Implementasi pendidikan karakter di SD Budi Mulia Dua Pandeansari Yogyakarta diwujudkan dalam kegiatan siswa di sekolah melalui kegiatan intrakurikuler, kegiatan ekstrakurikuler serta budaya sekolah. Kegiatan intrakurikuler meliputi penyusunan Rencana Pelaksanaan Pembelajaran (RPP), pelaksanaan pembelajaran, manajemen kelas dan pengembangan kurikulum. Sedangkan kegiatan ekstrakurikuler meliputi tapak suci, tari tradisional, berenang dan melukis. Katakter yang dapat diinternalisasikan ke dalam diri peserta didik adalah percaya diri, kemandirian, disiplin, tanggung jawab, cinta tanah air dan religius. Pada kedua kegiatan tersebut yang mencakup kegiatan intrakurikuler dan kegiatan 
ekstrakurikuler, terkandung nilai-nilai karakter yang diharapkan bahwa peserta didik khususnya peserta didik SD Budi Mulia Dua Pandeansari Yogyakarta tidak hanya 
mampu menjalani berbagai kegiatan, tetapi diharapkan pula mampu untuk membangun serta mengintegrasi nilai-nilai karakter yang ada di dalamnya.

\title{
B. Strategi pembentukan karakter melalui hidden curriculum
}

\begin{abstract}
Strategi Pendidikan Kewarganegaraan (PKn) pada Sekolah Dasar (SD) sebagai upaya untuk pembentukan karakter melalui hidden curriculum (kurikulum tersembunyi) dapat dilaksanakan melalui berbagai macam strategi.Strategi yang dapat digunakan sebagai upaya perwujudan terbentuknya karakter positif didalam kepribadian individu khususnya bagi peserta didik pada usia SD melalui hidden curriculum (kurikulum tersembunyi), dapat diterapkan diantaranya melalui cara-cara sebagai berikut:
\end{abstract}

1. Revitalisasi nilai-nilai Pancasila

Revitalisasi atau perbuatan untuk menghidupkan kembali nilai-nilai pancasila yang bersifat vital dan sangat diperlukan pelaksanaannya didalam kehidupan sehari-hari untuk pembentukan karakter serta jati diri bangsa yang dapat diaplikasikan melalui kegiatan pembelajaran PKn yang aktif serta menyenangkan.

Terkait dengan perkembangan teknologi dan globalisasi yang terjadi dewasa ini, menurunnya nilai-nilai moralitas yang tertanam didalam kepribadian individu semakin 
meningkat. Hal ini disebabkan oleh berbagai macam faktor yang dapat mendorong penurunan nilai-nilai moralitas itu 
terjadi, salah satunya yaitu sedikitnya pemahaman mereka mengenai implementasi nilai-nilai luhur pancasila. Pentingnya pengetahuan serta pemahaman mengenai nilai-nilai luhur pancasila sangat penting untuk dilakukan, mengingat bahwa modal dasar tersebut merupakan character and nation building yang berfungsi sebagai pembentuk kekuatan bangsa.

Pasal 3 Undang-undang No. 20 Tahun 2003 menyatakan bahwa, "pendidikan nasional berfungsi mengembangkan kemampuan dan membentuk watak serta peradaban bangsa yang bermartabat dalam rangka mencerdaskan kehidupan bangsa, bertujuan untuk berkembangnya potensi peserta didik agar menjadi manusia yang beriman dan bertaqwa kepada Tuhan Yang Maha Esa, berakhlak mulia, sehat, berilmu, cakap, kreatif, mandiri dan menjadi warga negara yang demokratis serta bertanggung jawab."

Berdasarkan fungsi pendidikan nasional yang telah dikemukakan diatas, peran Pendidikan Kewarganegaraan (PKn) sebagai upaya untuk mewujudkan fungsi dan tujuan tersebut dapat dilaksanakan.

Didalam pelaksanaan pembelajaran Pendidikan Kewarganegaraan (PKn) sebagai 
subjek untuk mencapai tujuan pendidikan nasional, peserta didik dituntut untuk memiliki kemampuan berfikir 
secara rasional dan kritis sesuai dengan tingkat perkembangan kemampuan mereka, berperilaku sesuai norma serta kreatif dalam melakukan berbagai kegiatan yang positif dimanapun mereka berada secara cerdas dan baik. Kegiatan pembelajaran Pendidikan Kewarganegaraan (PKn) ini dapat diorganisasikan ke dalam bentuk belajar sambil berbuat (learning by doing), belajar memecahkan masalah sosial (social problem solving learning), belajar melalui perlibatan sosial (socio-participatory learning) serta belajar melalui kontak sosial yang dapat dilakukan baik dengan keluarga, lingkungan sekolah maupun masyarakat guna meningkatkan interaksi sosial didalam konteks kehidupan sehari-hari.Dengan demikian, kegiatan pembelajaran

Pendidikan Kewarganegaraan (PKn) dapat digunakan sebagai salah satu strategi untuk merevitalisasi nilai-nilai pancasila sebagai upaya untuk pembentukan karakter serta penguatan jati diri bangsa Indonesia.

2. Menerapkan Pembelajaran Aktif, Kreatif, Efektif dan Menyenangkan (PAKEM)

Mewujudkan pembelajaran Pendidikan Kewarganegaraan (PKn) melalui kegiatan Pembelajaran Aktif, Kreatif, Efektif dan Menyenangkan (PAKEM) yang bertujuan untuk mengintegrasikan serta menyemaikan nilai-nilai 
karakter positif ke dalam tingkah laku peserta didik didalam kehidupan sehari-hari. Kegiatan pembelajaran ini tidak menyimpang terlalu jauh dengan kegiatan pembelajaran yang biasa 
dilakukan didalam proses belajar pada umumnya, hanya saja terdapat nilai-nilai karakter didalam setiap kegiatan pembelajaran yang dilakukan, baik secara sadar maupun tanpa sadar. Kegiatan pembelajaran tersebut dapat dilakukan sebagai berikut:

a. Perencanaan pembelajaran

Pada awal tahap proses kegiatan pembelajaran perlu adanya perencanaan berbagai komponen yang menunjang pembelajaran itu sendiri, diantaranya silabus, RPP serta bahan ajar yang berlandaskan pendidikan karakter dan mengintegrasi nilai-nilai karakter di dalamnya.

b. Pelaksanaan pembelajaran

1) Kegiatan pendahuluan

Penanaman nilai pada kegiatan ini dapat dilakukan sebagai berikut:

a) Guru datang tepat waktu (nilai yang ditanamkan: disiplin)

b) Guru mengucapkan salam kepada peserta didik (nilai yang ditanamkan: santun, peduli)

c) Guru dapat mempersilahkan salah satu dari peserta didik untuk memimpin doa sebelum kegiatan pembelajaran dimulai (nilai yang ditanamkan: religius, partisipatif, hormat pada guru) 
d) Guru melaksanakan pengecekan presensi (nilai yang ditanamkan: disiplin)

e) Guru menegur peserta didik apabila ada diantaranya yang datang terlambat (nilai yang ditanamkan: disiplin, santun, peduli)

f) Guru menyampaikan butir-butir nilai yang akan dicapai dalam pembelajaran (nilai yang ditanamkan: peduli)

2) Kegiatan inti

Kegiatan ini dapat dilaksanakan melalui tiga tahap, diantaranya kegiatan eksplorasi, elaborasi dan konfirmasi yang tetap menanamkan nilai-nilai karakter disetiap pelaksanaan pembelajaran.

a) Kegiatan eksplorasi

1.) Guru mempersilahkan peserta didik untuk bebas mengumpulkan informasi sebanyak-banyaknya dari berbagai sumber yang sesuai dengan tema yang sedang mereka pelajari (nilai yang ditanamkan: mandiri, berfikir kritis, logis, kreatif 
dan

rasional

serta

kerjasama) 
2.) Guru dapat menggunakan berbagai macam pendekatan didalam pembelajaran yang bersifat menantang peserta didik guna menumbuhkan minat serta motivasi peserta didik dalam belajar (nilai yang ditanamkan: kreatif dan kerja keras)

3.) Guru dapat melibatkan peserta didik didalam kegiatan pembelajaran secara aktif dan menyenangkan (nilai yang ditanamkan: percaya diri dan mandiri)

4.) Guru selalu memberikan fasilitas kepada peserta didik selama kegiatan pembelajaran (nilai yang ditanamkan: mandiri, kerja keras dan teliti)

b) Kegiatan elaborasi

1.) Pembiasaan

kegiatan membaca serta menulis melalui tugas yang sedang diselesaikan (nilai yang ditanamkan: tekun, kreatif, gemar membaca) 
2.) Guru menyediakan fasilitas dalam diskusi kelas (nilai yang ditanamkan: kreatif, kritis, 
analitis, santun dan

saling menghargai)

3.) Guru menyediakan fasilitas dalam kegiatan pembuatan laporan hasil kerja baik secara individu maupun secara kelompok (nilai yang ditanamkan: mandiri, kerja sama, tanggungjawab dan menghargai)

c) Kegiatan konfirmasi

1.) Guru memberikan umpan balik yang bersifat positif kepada peserta didik (nilai yang ditanamkan: percaya diri, santun dan saling menghargai)

2.) Guru melaksanakan refleksi atas kegiatan pembelajaran yang telah dilakukan bersama- sama dengan peserta didik (nilai yang ditanamkan: menerima keadaan)

3) Kegiatan penutup

a) Guru dan peserta didik membuat kesimpulan mengenai kegiatan pembelajaran serta materi pelajaran yang telah diterima 
(nilai yang ditanamkan: kritis, logis dan kerja sama) 
b) Guru melaksanakan penilaian terhadap proses pembelajaran yang telah terlaksana (nilai yang ditanamkan: jujur, menerima kelebihan dan kekurangan)

c) Guru melaksanakan perencanaan tindak lanjut (nilai yang ditanamkan: kreatif)

d) Guru memfasilitasi siswa untuk berdoa sebelum berakhirnya kegiatan pembelajaran (nilai yang ditanamkan: religius, partisipatif, hormat pada guru). 


\section{KESIMPULAN}

Berdasarkan penjelasan mengenai strategi pembelajaran pendidikan kewarganegaraan (pkn)pada sekolah dasar (SD) dalam pembentukan karakter melalui hidden curriculum (kurikulum yang tersembunyi) diatas, maka dapat disimpulkan bahwa:

Untuk menyukseskan pendidikan karakter di berbagai lembaga pendidikan termasuk di sekolah, maka segenap dewan guru beserta kepala sekolah harus proaktif dalam mencari informasi tentang berbagai macam nilai karakter yang terjadi di masyarakat dalam rangka memutakhirkan program pendidikan, khususnya bagi pendidikan karakter. Selain dapat mengajarkan strategi yang tepat untuk membentuk karakter di dalam diri peserta didik melalui Pendidikan Kewarganegaraan (PKn) dan hidden curiculum (kurikulum tersembunyi) yang dilaksanakan melalui kegiatan intrakurikuler dan ekstrakurikuler, guru juga dituntut untuk memiliki wawasan yang cukup mengenai pengetahuan dan pengalaman tentang nilai-nilai karakter yang berkembang serta mengetahui bagaimana mengajarkannya kepada peserta didik. 


\section{BAB 3}

Penyusunan Silabus Dan Rencana Pelaksanaan Pembelajaran, Serta Pengaplikasiaan Dasar Mengajar Dalam Pembelajaran Pkn SD

CP-MK Capaian Pembelajaran Mata Kuliah :

A. Mahasiswa dapat memahami cara penyusunan Silabus Dan Rpp Pkn Sd Sesuai Kurikulum K-13

B. Mahasiswa dapat mendeskripsikan

Tinjauan Umum Rencana Pelaksanaan

Pembelajaran (Rpp) Pada K-13

C. Mahasiswa dapat Mengaplikasikan Delapan Keterampilan Dasar Belajar Mengajar Dalam Simulasi Pembelajaran Pkn Sd

A. Menyusun Silabus dan RPP PKn SD Sesuai Kurikulum K-13 1. Pengertian Silabus

Silabus adalah suatu rencana pembelajaran yang terdapat pada suatu kelompok mata pelajaran dengan tema tertentu, yang akan mencakup standar kompetensi, kompetensi dasar, indikator, alokasi waktu, materi pembelajaran, penilaian, serta sumber belajar yang dikembangkan oleh setiap satuan pendidikan. (Trianto, 2008: 34)

Di dalam dunia pendidikan tentunya tidak lepas dengan yang namanya sebuah Silabus dan Rencana Pelaksanaan Pembelajaran 
(RPP). Pengembangan silabus diserahkan kepada guru akan berbeda antara satu guru dengan guru lain, baik dalam satu daerah 
ataupun dalam daerah yang berbeda. Suatu silabus minimal memuat enam komponen utama yaitu : Standar kompetensi, Komptensi isi, kompetensi dasar, indikator, materi standar, standar proses ( kegiatan belajar mengajar), standar penilaian. Pengembangan terhadap komponen-komponen tersebut merupakan kewenangan mutlak guru, termasuk pengembangan format silabus, dan penambahan komponen-komponen lain dalam silabus di luar komponen minimal. Semakin rinci silabus, maka semakin membantu memudahkan guru dalam menjabarkannya ke dalam rencana pelaksanaan pembelajaran.

\section{Prinsip Pengembangan Silabus}

Dalam KTSP, pengembangan silabus diserahkan sepenuhnya kepada setiap satuan pendidikan, khususnya bagi yang sudah mampu melakukannya. Oleh karena itu, setiap satuan pendidikan diberi kebebasan dan keleluasan dalam mengembangakan silabus sesuai dengan kondisi dan kebutuhan masing-masing. Agar pengembangan silabus yang dilakukan oleh setiap satuan pendiidkan tetap berada dalam bingkai pengembangan kurikulum nasional (standar nasional) maka harus memperhatikan prinsip-prinsip pengembangan silabus.

Pengembangan silabus antara lain : ilmiah, 
relevan, fleksibel, kontinuitas, konsisten, 
memadai, aktual, kontekstual, efektif dan efesien. (Trianto, 2008: 34-35),

Dalam mengembangkan silabus harus memenuhi beberapa prinsip, yaitu: (1) Ilmiah, yaitu bahwa keselurahan materi dan kegiatan yang menjadi muatan dalam silabus itu harus benar, logis serta dapat dipertanggungjawabkan secara keilmuwan. (2) Relevan, yaitu kesesuaian atau keserasian antara silabus dengan kebutuhan dan tuntutan kehidupan masyarakat pemakai lulusan. Sehingga sesuai dengan kebutuhan tenanga kerja dilapangan baik secara kuatitas maupun kualitas.

Fleksibel, yaitu bahwa pelaksana program, peserta didik, dan lulusan memiliki ruang gerak dan kebebasan dalam bertindak.

Kontinuitas, yaitu bahwa setiap program pembelajaran yang di kemas dalam suatu silabus memiliki keterkaitan satu sama lain dalam membentuk kompetensi dan pribadi peserta didik. (5) Konsisten, yaitu memiliki hubungan yang konsisten (ajeg) dalam membentuk kompetensi-kompetensi peserta didik, antara standar kompetensi, kompetensi dasar, indikator, materi pokok, sumber belaar, pengalaman belajar serta sistem penilaian. (6) Memadai, yaitu bahwa ruang lingkup indikator, materi standar, pengalaman belajar, sumber belajar, sistem penilaian serta pencapaiannya 
yang ditunjang oleh sarana dan prasarana yang memadai. (7) Aktual dan Kontekstual, yaitu bahwa ruang lingkup terlaksana 
dalam proses pembelajaran. Sehingga harus memperhatikan perkembangan-perkembangan pengetahuan teknologi dan keadaan berlangsung dikehidupan masyarakat. (8) Afektif, yaitu dapat diwujudkan dalam kegiatan pembelajaran nyata di kelas atau di lapangan, sebaliknya silabus tersebut dapat dikatakan kurang efektif apabila banyak hal yang tidak dapat dilaksanakan. (9) Efesien, dalam silabus bisa dilihat dengan cara membandingkan antara biaya, tenaga, waktu yang dilakukakn dalam pembelajaran dengan hasil yang dicapai atau kompetensi yang dapat dibentuk oleh peserta didik.

\section{Tugas dan tanggungjawab pengembangan silabus}

Pengembangan silabus melibatkan berbagai pihak antara lain Badan Penelitian dan Pengembangan (Balitbang), Depdiknas, Badan Standar Nasional Pendidikan (BSNP), Pusat Kurukulum (Puskur), Dinas Pendidikan Provinsi, Dinas Pendidikan Kota dan Kabupaten, serta satuan pendidikan yang akan mengimplementasikan kurikulum, sesuai dengan kapasitas dan proporsinya maisngmasing (Sri Wahyuni: 2013)

1. Balitbang Depdiknas 
Peran dan tanggung jawab Balitbang Depdiknas dalam pengembangan silabus sebagai berikut: mengembangkan model silabus untuk diadopsi oleh 
satuan pendidikan yang belum siap mengembangkan KTSP sendiri, melakukan penelitian berakitan dengan perencanaa, pelaksanaan, dan penilaian KTSP disekolah, membuat contoh silabus yang efektif dan efesien, serta mudah untuk diterapkan dalam pembelajaran.

\section{BSNP Depdiknas}

Peran dan tanggung jawab BSNP dalam pengembangan silabus sebagai berikut: membuat contoh silabus yang efektif dan efesien, serta mudah untuk diterapkan dalam pemebelajaran, menyelenggarakan seminar, dan loka karya untuk meningkatkan kualitas implementsi kurikulum, menguji kelayakan silabus melalui penilaian ahli, yang melibatkan berbagai ahli, baik ahli kurikulum, ahli bahasa maupun ahli bidang studi.

3. Pusat Kurikulum Depdikanas

Peran dan tanggung jawab Puskur dalam pengembangan silabus sebagai berikut: memberiakn masukan keapda BSNP berkaitan dengan contoh atau model silabus yang dikembangkan, membantu BSNP dalam mengembangkan contoh silabus yang efektif dan efesien, serta mudah untuk diterapkan dalam pemebelajaran, bersama-sama atau terpisah menyelenggarakan seminar, dan loka karya untuk meningkatkan kualitas implementasi kurikulum. 
4. Dinas Pendidikan Provinsi

Peran dan tanggung jawab Dinas Pendidikan Provinsi dalam pengembangan silabus sebagai berikut: memberikan dukungan sumber-sumber daya pendidikan untuk kepentingan penyusunan silabus, memantau penyusunan silabus dan implementasi kurikulum secara keseluruhan pada tingkat kabupaten dan kota, menyesuaikan buku teks pembelajaran dengan silabus, baik silabus yang dikembangkan oleh diknas maupun yang dikembangkan oleh satuan pendidikan.

5. Dinas Pendidikan Kabupaten dan Kota

Peran dan tanggung jawab Dinas Pendidikan Kabupaten dan Kota dalam pengembangan silabus sebagai berikut: membentuk tim pengembang silabus tingkat kabupaten/Kota dan mengembangkan silabus sesuai dengna kondisi dan kebutuhan daerah, memberikan kemudahan bagi sekolah yang mampu mengembangkan silabus sendiri, memberikan dukungan sumber-sumber daya pendidikan untuk kepentingan penyusunan silabus.

6. Sekolah

Peran dan tanggung jawab sekolah dalam pengembangan silabus sebagai berikut: membentuk tim pengembangan silabus kurikulum tingkat sekolah bagi yang mampu melakukannya, 
meningkatkan kualitas silabus dan kualitas pembelajaran secara terus menerus dan bekesinambungan. mengidentifikasi kompetensi sesuai dengan perkembangan peserta 
didik dan kebutuhan daerah yang perlu dikembangkan kedalam silabus.

7. Kelas/Guru

Peran dan tanggung jawab Dinas kelas/guru dalam pengembangan silabus sebagai berikut: menganalisis rancangan kompetensi dan indikator kompetensi serta materi standar, menyusun RPP, mengembangkan Strategi Pembelajaran, mengembangkan media dan metode pembelajaran

\section{Prosedur pengembangan silabus}

Pengembangan Silabus K-13 dalam garis besar mencakup sebagai berikut : (a) mengisi kolom identitas, (b) mengkaji dan menganalisis standar kompetensi, (c) mengkaji dan menentukan Kompetensi isi dan kompetensi dasar, (d) mengidentifiaksi materi standar,

(e) mengembangkan pengalaman (standar proses), (f) merumuskan insikator pencapaian kompetensi, (g) menentukan jenis penilaian, (h) alokasi waktu, dan (i) menentukan sumber belajar.

\section{Proses pengembangan silabus}

Proses pengembangan silabus mencakup perencanaa, pelaksanaan, evaluasi maupun revisi (Abd. Syukur Ibrahim: 2013) 
1. Perencanaan

Pengumpulan referensi, informasi, serta mengidentifikasi sumber belajar termasuk dalam nara sumber yang diperlukan untuk pengembangan 
silabus. Dalam pengumpulan referensi dapat dilakukan dengan memanfaatkan perangkat teknologi dan informasi.

2. Pelaksanaan

Pelaksanaan penyusunan silabus dapat dilakukan dengan langkah-langkah sebagai berikut:

a. Merumuskan kompetensi dan tujuan pembelajaran, serta menentukan materi standar yang memuat kompetensi dasar, materi standar, hasil belajar dan indikator hasil belajar.

b. Menganalisis kesesuaian silabus dengan pengorganisasian pengalaman belajar.

3. Penilaian

Untuk melakukan penilaian silabus ini harus dilaksanakan secara berkala dan berkesinambungan, dengan menggunakan model- model penelitian.

4. Revisi

Revisi silabus harus dilakukan setiap saat, sebagai aktualisasi dari peningkatan kaulitas yang berkelanjutan.

\section{B. Tinjauan Umum Rencana Pelaksanaan Pembelajaran (RPP) pada K-13. \\ 1. Pengertian Rencana Pelaksanaan Pembelajaran (RPP)}


Rencana Pelaksanaan Pembelajaran (RPP) adalah sebuah rencana yang menggambarkan prosedur-prosedur pembelajaran guna untuk 
mencapai satu atau lebih kompetensi dasar yang ditetapkan dalam Standar Isi dan dijabarkan dalam silabus (Trianto, 2008:69).

RPP dapat dijadikan alat pemantau proses pembelajaran dalam mencapai ketuntasan kompetensi. RPP perlu dikembangkan untuk mengkoordinasikan komponen pembelajaran yaitu: kompetensi dasar, materi standar, indikator hasil belajar, serta penilaian. RPP sedikitnya mencakup tiga kegiatan antara lain: (a) Identifikasi kebutuhan, sesuatu yang harus dipenuhi untuk mencapai tujuan. Identifikasi kebutuhan bertujuan untuk mencakup dan memotivasi siswa agar kegiatan belajar dirasakan oleh mereka sebagai bagian dari kehidupannya dan mereka merasa memilikinya. (b) Identifikasi kompetensi, sesuatu yang ingin dimiliki oleh peserta didik, serta komponen utama dalam pembelajaran yang mempunyai peran penting dan menentukan arah pembelajaran. (c) Penyusunan program pembelajaran, bermuara pada RPP, sebagai produk program pembelajaran jangka pendek, yang mencakup komponen program kegiatan belajar dan proses pelaksanaan program. Komponen program mencakup KD, materi standar, metode, teknik, media, sumber belajar, waktu belajar serta daya dukung lainnya. 


\section{Fungsi RPP}

Terdapat dua fungsi RPP dalam K-13 antara lain fungsi perencanaan dan fungsi pelaksanaan. Fungsi perencanaan yaitu agar dapat mendorong guru untuk lebih siap dalam melakukan kegiatan pembelajaran dengan perencanaan yang matang. Sedangkan fungsi pelaksanaan yaitu kegiatan pembelajaran yang disusun secara sistematis untuk mengefektifkan proses pembelajaran yang direncanakan, dengan strategi yang tepat dan mumpuni.

\section{Prinsip Pengembangan RPP}

Beberapa prinsip yang harus diperhatikan dalam pengembangan RPP dalam menyukseskan implementasi KTSP, sebagai berikut :

1. Kompetensi yang dirumuskan dalam RPP harus jelas, konkrit kompetensi makin mudah diamati, makin tepat kegiatan-kegiatan yang harus dilakukan untuk membentuk kompetensi tersebut.

2. RPP harus sederhana, fleksibel, dapat dilaksanakan dalam kegaitan pembelajaran, serta pembentukan kompetensi peserta didik.

3. RPP harus dikembangkan secara utuh, meyeluruh serta jelas pencapaiannya.

\section{Cara pengembangan RPP}


Secara garis besar cara pengembangan RPP adalah mengisi kolom identitas, menentukan alokasi waktu, menentukan SK, KD serta Indikator yang terdapat pada silabus yang telah disusun, 
merumuskan tujuan pembelajaran yang sudah ditentukan, mengidentifikasi materi standar berdasarkan materi pokok yang tertera di silabus, menentukan metode pembelajaran yang akan digunakan, merumuskan langkah-langkah pembelajaran terdiri kegiatan awal, inti dan akhir, dan menyusun kriteria penilaian, lembar pengamatan,contoh soal, teknik penskoran.

\section{Kinerja Guru dalam Pengembangan RPP}

Terdapat 10 faktor yang dapat meningkatakn kinerja guru, baik faktor internal maupun eksternal yaitu dorongan untuk kerja, tanggung jawab terhadap tugas, minat terhadap tugas, penghargaan atau tugas, peluang untuk berkembang, perhatian dari kepala sekolah, hubungan interpersonal sesama guru, MGMP dan KKG, kelompok diskusi terbimbing, layanan perpustakaan.

\section{Mengaplikasikan Delapan Keterampilan Dasar Belajar Mengajar dalam Simulasi Pembelajaran PKn SD}

Keterampilan dasar tersebut adalah keterampilan bertanya, (2) keterampilan memberikan penguatan, (3) keterampilan mengadakan variasi, (4) keterampilan menjelaskan, (5) keterampilan membuka dan menutup pelajaran, (6) keterampilan membimbing diskusi,

(7) keterampilan mengelola kelas (8) dan keterampilan 
mengajar kelompok kecil 
1. Keterampilan Bertanya

Pada pembelajaran PKn SD Jenis keterampilan bertanya ada 2 macam yaitu, bertanya tingkat dasar dan bertanya tingkat lanjut. Perlu kita ketahui bahwa dalam keterampilan bertanya kebiasaan yang perlu kita hindari adalah, (1) mengulangi pertanyaan sendiri,

(2) mengulangi pertanyaan siswa, (3) menjawab pertanyaan sendiri, (4) mengajukan pertanyaan yang mengundang jawaban salah, (5) mengajukan pertanyaan ganda, (6) menunjuk dulu sebelum bertanya. Sebaiknya pertanyaan diajukan dulu, anak diberi kesempatan berpikir, baru ditunjuk, sehingga anak sudah punya konsep untuk menjawabnya/sudah siap dari hasil pikir tadi. Keterampilan bertanya diawali dari memberikan pertanyaan sehari-hari yang pasti dihadapi oleh semua orang,

Kualitas pertanyaan yang disampaikan guru akan menentukan kualitas jawaban yang diberikan siswa. Jenis keterampilan bertanya ada dua macam yaitu:

1) Keterampilan bertanya dasar

Keterampilan bertanya dasar merupakan kemampuan mengungkapkan pertanyaan dengan jelas dan singkat, yang dapat memberikan acuan bagi siswa agar lebih memusatkan perhatian pada materi. Pertanyaan sebaiknya menyebar dan menyeluruh. Lebih baik lagi, jika pertanyaan 
sekali- kali dilakukan secara bergiliran di antara siswa. Perlu ditekankan lagi bahwa guru tidak boleh menunjuk siswa dulu sebelum mengajukan pertanyaan, bahkan guru sebaiknya memberikan kesempatan siswa untuk berpikir untuk menjawab 
pertanyaan, dan pertanyaan yang

diberikan selayaknya dapat menuntun siswa.

2) Keterampilan bertanya lanjut

Keterampilan bertanya lanjut adalah kemampuan mengajukan pertanyaan yang dapat mengubah tuntutan kognitif, kemampuan mengatur urutan pertanyaan dengan baik, menggunakan pertanyaan pelacak, dan meningkatkan interaksi

2. Keterampilan Memberi Penguatan Pada pembelajaran PKn SD

Penguatan adalah keterampilan yang dapat memberi respon positif atas kinerja siswa yang baik. Hal ini perlu dilakukan dalam rangka menumbuhkan motivasi pada siswa agar meningkatkan kinerjanya supaya lebih baik lagi. Siswa yang kinerjanya belum baikpun sebaiknya perlu dimotivasi dengan penguatan agar tigak patah semangat.

Ada beberapa syarat dalam pemberian penguatan agar dapat berhasil menumbuhkan motivasi siswa, yaitu (1) suasana yang hangat dan antusias, (2) bermakna, (3) respon positif, (4) jelas sasaran, dan (5) bervariasi. Jenis penguatan ada 2 (dua) macam, yaitu:

(1) penguatan verbal, suatu penguatan yang disampaikan dengan kata-kata atau kalimat, (2) penguatan non verbal, suatu penguatan yang disampaikan dengan gerakan, pendekatan, mimik dan sentuhan. 
3. Keterampilan Mengadakan Variasi Pada Pembelajaran PKn SD

Keterampilan mengadakan variasi adalah keterampilan dalam membuat perubahan-perubahan cara (inovasi) dalam kegiatan proses pembelajaran. Hal ini sangat penting dilakukan karena dengan adanya variasi dalam cara penyampaian pembelajaran, suasana belajar menjadi tidak membosankan.

Tujuan dari keterampilan mengadakan variasi adalah (1) mengurangi kebosanan, dan (2) meningkatkan motivasi yang mengarah pada peningkatan kualitas proses dan hasil belajar. Dalam menyampaikan materi PKn apa aanda dapat membuat variasi pada kelas Anda? Jika menginginkan siswa senang tentunya Anda sering mengkondisi kelas seperti itu.

4. Keterampilan Menjelaskan Pada

Pembelajaran PKn SD Keterampilan

menjelaskan adalah keterampilan

dalam cara menyajika informasi yang telah disusun secara terorganisasi dan sistimatis sehingga mudah untuk dipahami dan dimengerti. Tujuan dari keterampilan menjelaskan adalah untuk membantu memudahkan siswa dalam memahami konsep, bernalar, dan terlibat dalam berpikir, dan untuk mendapat balikan, pertanyaan dan pendapat dari siswa terhadap isi informasi yang dijelaskan tersebut. Komponen keterampilan 
menjelaskan ada 2 yaitu (1) merencanakan, yang berkaitan dengan penyusunan isi pesan yang akan disampaikan dan kesesuaian pesan dengan karakteristik siswa yang akan menerima, (2) 
menyajikan, yang berkaitan dengan cara dan metode dalam menyampaikan penjelasan yang meliputi (a) kejelasan dalam berbahasa, kelancaran dan ucapan,

(b) penggunaan contoh dan ilustrasi, pemberian tekanan pada pesan-pesan penting melalui suara dan ikhtisar, (d) balikan dengan memberi kesempatan mengajukan pertanyaan dan mimik siswa.

5. Keterampilan Membuka dan Menutup Pelajaran dalam Pembelajaran PKn SD.

Keterampilan membuka pelajaran adalah keterampilan dalam menciptakan kesiapan mental siswa untuk mulai pembelajaran. Terdapat beberapa komponen yang harus di perhatikan dalam membukapelajaran, yaitu menarik perhatian, menimbulkan motivasi, memberi acuan, serta membuat kaitan. Keterampilan menutup pelajaran adalah keterampilan untuk mengakhiri pelajaran. Terdapat beberapa komponen dalam menutup pelajaran yaitu meninjau kembali, mengevaluasi penguasaan, memberikan tindak lanjut.

6. Keterampilan Membimbing Diskusi Kelompok Kecil Dalam Pembelajaran PKn SD

Kita tentu saja sering melakukan diskusi kelompok kecil. Pelaksanaan diskusi kelompok dengan jumlah peserta yang kecil biasanya lebih efektif dari pada yang jumlah pesertanya besar. 
Kelompok kecil ini biasanya diikuti peserta yang jumlahnya kurang dari sepuluh orang, topiknya jelas, ada interaksi tatap muka, dan berlangsung sistematis. Keterampilan membimbing diskusi kelompok kecil ini meliputi 
keterampilan untuk: (a) membimbing siswa untuk dapat memusatkan perhatian pada permasalahan, (b) memperjelas masalah, (c) menganalisis pandangan mahasiswa, (d) menyebarkan kesempatan berpartisipasi, dan (e) menutup diskusi yang biasanya disertai kesimpulan atau penegasan dari guru.

7. Keterampilan Mengelola Kelas Dalam Pembelajaran PKn SD

Pengertian keterampilan mengelola kelas adalah keterampilan dalam menciptakan kondisi kelas yang baik untuk berlangsungnya pembelajaran yang optimal. Tujuan pengelolaan kelas adalah (a) mendorong mahasiswa untuk bertanggung jawab, (b) menyadari kebutuhan mahasiswa, dan (c) memberikan respon terhadap perilaku mahasiswa.

8. Keterampilan Mengajar Kelompok Kecil dan Perorangan dalam Pembelajaran PKn SD

Keterampilan mengajar kelompok kecil dan perorangan adalah keterampilan untuk mengadakan

(1) pendekatan positif secara pribadi, mengorganisasikan siswa (3) membimbing dan memudahkan belajar, (4) merencanakan dan melaksanakan kegiatan belajar mengajar. 


\section{KESIMPULAN}

Silabus yaitu perencanaan dalam sebuah pembelajaran yang terdapat tema tertentu dalam mata pelajaran yang mencakup identitas sekolah, SK, KD, materi pembelajaran, kegiatan pembelajaran, indikator pencapaian pembelajaran, penilaian, alokasi waktu, serta sumber belajar. Karena sebelum melakukan kegiatan belajar mengajar tentunya seorang guru harus merencanakan terlebih dahulu kegiatan-kegaitan yang akan dicapai. Hal yang harus diperhatikan dalam prinsip pengembangan silabus meliputi ilmiah, relevan, fleksibel, kontinuitas, konsisten, memadai, aktual, afektif, efesien. Agar dalam pengembangan silabus tetap pada bingkai pengembangan kurikulum nasional (standar nasional). Sedangkan Rencana Pelaksanaan Pembelajaran yaitu rencana atau rancangan dalam pembelajaran yang dilakukan untuk mencapai kompetensi yang telah ditetapkan dalam standar isi dan yang sudah dijabarkan didalam silabus. Agar dapat mendorong guru untuk siap dalam melakukan kegiatan pembelajaran dalam kelas. Untuk pengembangan RPP dalam garis beras yang perlu diperhatikan yaitu identitas sekolah, SK, KD, indikator, tujuan pembelajaran, materi pokok, metode pembelajaran, langkah-langkah pembelajaran (kegiatan awal, kegiatan inti dan kegiatan penutup), kriteria penilaian, lembar pengamatan, contoh soal, teknik penskoran.

Sehingga dengan adanya silabus dan RPP guru akan lebih mudah untuk melakukan pembelajaran dan 
mengaplikasikan saat proses pembelajaran berlangsung. Dan keterampilan dasar yang harus miliki oleh seorang guru 
yaitu keterampilan bertanya, keterampilan memberi penguatan, keterampilan mengadakan variasi, keterampilan menjelasakan pelajaran, keterampilan mengelola kelas, keterampilan mengajar kelompok kecil dan perorangan. Agar siswa juga tidak bosan saat melakukan belajar dalam kelas. Maka membuat pembelajaran lebih berkesan dan bermakna untuk siswa. 


\section{BAB 4}

\section{Langkah - Langkah Pemilihan Dan Penggunaan Metode Dan Media Pembelajaran Pkn SD}

\section{CP-MK Capaian Pembelajaran Mata Kuliah :}

\section{A. Mahasiswa dapat memahami Tinjauan Umum Metode Pembelajaran Pada Pkn di SD \\ B. Mahasiswa dapat mendeskripsikan Tinjauan Umum Media Pembelajaran Pada Pkn SD}

Pembelajaran Pendidikan Kewarganegaraan (PKn) disekolah pada dasarmya kurang begitu diminati oleh para siswa SD, SMP, SMA atau mahasiswa. Hal ini disebabkan adanya beberapa faktor yaitu kurangnya profesionalitas dan rendahnya guru dalam mengelola pembelajaran dikelas, sarana dan prasarana yang tidak begitu memadai serta metode dan media pembelajaran yang kurang kreatif dan menarik bagi peserta didik.

Dalam pelaksanaan pembelajaran Pendidikan Kewarganegaraan (PKn) di sekolah dasar, guru perlu mengembangkan strategi atau taktik yang tepat, metode dan media pembelajaran yang efektif. Hal ini akan membantu guru dalam memahami dan membantu siswa untuk berlatih mengamalkan nilai moral pancasila dan budi pekerti yang dipelajari disekolah. Metode dan media pembelajaran mempunyai unsure yang penting dalam kegiatan pembelajaran di kelas.metode pembelajaran dapat diartikan sebagai cara atau teknik penyampaian materi pembelajaran yang harus di kuasai oleh guru. Sementara media pembelajaran 
dapat diartikan sebagai perantara yang dapat diartikan sebagai perantara yang dapat digunakan 
untuk menyampaikan pesan berupa materi kepada siswa.kedua unsure pentimg dalam proses belajar mengajar ini harus dapat dikuasai oleh guru. Oleh karena itu seorang guru yang professional harus memiliki kemampuan dalam mengembangkan dan memilih metode serta media pembelajaran khususnya pada mata pelajaran Pendidikan Kewarganegaraan (Pkn).

\section{A. Tinjauan Umum Metode Pembelajaran pada PKn SD}

Metode merupakan salah satu cara yang digunakan guru atau pengajar dalam pembelajaran yang ingin dicapai. Metode juga bisa di rtikan sebagai suatu pengetahuan tentang cara mengajar yang dilakukan oleh guru. Jika metode yang digunakan oleh guru atau pengajar itu tepat maka proses pembelajaran akan berjalan dengan baik.

Metode pembelajaran adalah suatu cara yang digunakan oleh pengajar dalam sebuah pembelajaran dengan cara mempersiapkan penuh dalam menyajikan untuk menyajikan sebuah materi pembelajaran dengan tertaur dan yang berbeda untuk mencapai hasil belajar dengan kondisi yang berbeda. (Sudrajat,2009)

Maksud dari pernyataan diatas yaitu metode pembelajaran ini berorientasi pada proses 
dan hasil. Berorientasi pada proses maksudnya dalam menentukan metode pembelajaran, seorang guru menentukan cara sekaligus hasil belajar yang dapat dicapai oleh peserta didik. Hasil pembelajaran yang 
dicapai oleh peserta didik dapat dapat berupa hasil nyata yaitu hasil yang dicapai dari penggunaan suatu metode dibawah kondisi tertentu.

Seorang guru dalam memilih metode pembelajaran Pendidikan Kewarganegaraan (PKn) harus dilakukan dengan kriteria agar pembelajaran yang diterapkannya efektif dan efisien.Beberapa pertimbangan dalam pemiliahan metode pembelajaran yang dilakukan oleh guru yang akan dipakai dalam proses belajar mengajar :

1.) Tujuan Pembelajaran.

Mempertimbangkan tujuan pembelajaran adalah syarat yang harus dilakukan dalam pemilihan metode yang akan digunakan. Tujuan pembelajaran dalam Pendidikan Kewarganegaraan (PKn) dalam bernbagi tingkat pendidikan berbeda. Namun, dalam hal tema pembelajaran

Pendidikan Kewarganegaraan (PKn) seringkali muncul tema yang sama dalam jenjang yang berbeda. Disinilah tujuan pembelajaran yang dalam kurikulum disebut sebagai kompetensi inti dan kompetensi dasar diperlukan.

2.) Pengetahuan awal peserta didik.

Guru dalam memilih metode pembelajaran juga melihat pengetahuan awal yang dimiliki oleh para peserta didiknya. Misalnya peserta didik belum memiliki prinsip, konsep serta pengalaman, maka besar kemungkinannya peserta didik tersebut belum bisa 
menggunakan metode yang bersifat belajar mandiri.Metode yang dapat digunakan 
hanyalah metode ceramah, metode demonstrasi, metode bermain peran, dan metode praktik.

3.) Karakter materi yang diajarkan.

Karakter materi dalam pembelajaran Pendidikan Kewarganegaraan (PKn) mempunyai sifat yang beragam.Dalam pembelajaran Pendidikan Kewarganegaraan (PKn) terdapat materi sikap patriotisme dan nasionalisme. Kedua sikap ini dapat diajarkan dengan metode yang sama.

4.) Alokasi waktu dan sarana penunjang

Alokasi waktu dan sarana penunjang pembelajaran yang tersedia merupakan pertimbangan sendiri dalam pemilihan metode pembelajaran. Dalam tiap jam pelajaran yang tersedia, perlu dibagi waktu yang akan dipergunakan oleh masing-masing metode pembelajaran.

5.) Jumlah Peserta didik.

Metode pembelajaran yang digunakan juga dapat dilihat dari jumlah peserta didik.Misalnya guru mengajar didalam kelas yang besar dengan jumlah peserta didik yang banyak, maka guru biasanya menggunakan metode ceramah karena metode tersebut lebih efektif.Akan tetapi metode ceramah tersebut memiliki banyak kelemahannya.

Berbagai jenis metode pembelajaran yang dapat diterapkan dalam pembelajaran Pendidikan 
Kewarganegaraan (PKn) antara lain sebagai berikut : 
A. Metode Ceramah.

Metode Ceramah adalah suatu cara mengajar yang paling sering digunakan oleh guru dalam mengajar karena cara mengajarnya ini yang paling mudah dilakukan oleh guru dan merupakan cara mengajar yang paling tradisional dengan penyampaian materinya berupa penuturan dan penerangan lisan guru kepada peserta didik. (Dr.Hamdani,M.A,2011: 278)

Maksud dari pengertian diatas adalah metode ceramah ini sering digunakan oleh guru dalam mengajar apabila materi pelajaran yang ingin disampaikan banyak mengandung hal-hal yang memerlukan penjelasan dari guru.Metode ini juga merupakan metode pembeljaran yang murah dan mudah digunakan karena hanya mengandalkan suara guru tanpa memerlukan persiapan yang rumit.Kelebihan dari metode ceramah ini adalah dapat digunakan dalam proses pembelajaran dengan menggunakan metode lainnya, misalnya metode Tanya jawab atau diskusi karena dalam materi pelajaran Pendidikan Kewarganegaraan (PKn) cocok dengan metode Tanya jawab. Selain itu peserta didik tidak hanya mendengarkan penjelasan dari guru tetapi juga dapat 
berbicara dalam proses kegiatan belajar dikelas. Namun kelemahan dari metode ceramah adalah materi 
yang dikuasai oleh peserta didik dari hasil ceramah akan terbatas pada yang dikuasai oleh guru.

B. Metode Cerita.

Metode cerita yaitu metode pembelajaran yang didalam mengajarnya guru menanamkan sebuah nilai dan moral kepada peserta didik dengan cara menggunakan karakter atau tokoh-tokoh melalui sebuah cerita. Cerita legenda, hikayat dan dongeng bersejarah lokal juga bisa digunakan oleh guru dalam menanamkan nilai dan moral kepada peserta didik. Contohnya pelajaran Pendidikan Kewarganegaraan (PKn) dalam materi sikap nasionalisme dan patriotisme, guru akan menceritakan bagaimana sikap para pahlawan pada zaman dahulu dan menceritakan pula bagaimana sikap nasionalisme dan patriotisme yang harus dimiliki.

C. Metode Tanya Jawab.

Metode Tanya Jawab merupakan metode mengajar yang bersifat langsung karena dalam pembelajarannya terjadi dialog antara guru dan peserta didiknya. Ketika dalam pembelajaran guru dapat bertanya kepada peserta didik dan peserta didikpun dapat menjawab atau sebaliknya peserta 
didik akan bertanya dan guru akan menjawab karena dalam metode ini 
terjadi timbal balik antara guru dan peserta didik. (Nana Sudjana,2010: 78)

Menggunakan metode tanya jawab atau diskusi harus ada sebuah permasalahan yang didiskusikan. Karena jika tidak adanya permasalahan maka tidak ada hal yang perlu untuk didiskusikan oleh peserta didik. Metode Tanya jawab ini lebih dianjurkan untuk materi pembelajaran Pendidikan Kewarganegaraan (PKn) karena mata pelajaran tersebut menggunakan teknik Value Inquiry.

D. Metode Penugasan.

Metode penugasan adalah suatu cara guru mengajar dengan menanamkan kebiasaan dan dapat memperoleh suatu ketangkasan, ketepatan dan keterampilan pada peserta didik. (Syaiful Sagala,2012)

Guru dalam menggunakan metode penugasan dengan tujuan agar siswa memperoleh pengalaman langsung, nyata, bekerja mandiri dan jujur. Misalnya guru memberikan tugas berupa menuliskan pengalaman dalam menolong teman. Jadi peserta didik dapat menulis peristiwa apa dia 
menolong adiknya, bagaimana cara dia menolong adikknya, bagaimana perasaannya ketika dia memberikan pertilongan kepada adiknya, dan seterusnya. 
E. Metode Permainan atau Kompetisi.

Metode permainan atau kompetensi adalah metode yang dapat membangkitkan motivasi serta menciptakan suasan senang dalam belajar bagi peserta didik.

Belajar sambil bermain peserta didik akan mengenal tentang dunianya, belajar tentang hidup bersama, belajar arti persahabatan, belajar tentang lingkungan yang ada disekitarnya, belajar tentang bahasa, belajar tentang moral dan sebagainya. Bermain juga merupakan kebutuhan peserta didik yang seharusnya difasilitasi oleh para orang tua, guru atau orang dewasa pada umumnya. (Tarwiyah,2012: 1)

Peserta didik akan mudah menyerap materi pelajaran ketika dalam suasana yang menyenangkan. Oleh karena itu guru mengajar menggunakan metode ini dengan menyajikan bahan ajar melalui permainan. Dengan menggunakan metode ini dapat membuat atau menciptakan permainan yang akan digunakan dalam mengajar. Misalnya dapat berupa teka teki bergambar dan lainnya dan didalam permainan tersebut memuat isi pesan berupa nilai, moral dan norma sesuai dengan tuntutan Pendidikan Kewarganegaraan (PKn). 


\section{B. Tinjauan Umum Media Pembelajaran pada PKn SD}

Media adalah suatu alat yang secara fisik terdiri dari buku, tape-recorder, kaset, video kamera, video recorder, film, slide, foto, gambar, grafik, televisi, dan computer yang digunakan oleh pengajar dalam penyampaian isi materi dalam kegiatan pembelajaran. (Ashar, 2010: 4)

Maksud dari pengertian diatas adalah dalam media yang digunakan dikelas selain dengan buku, guru dalam menyampaikan isi materi belajar bisa juga menggunakan tape-recorder, kaset, video kamera, video recorder, film, slide, foto, gambar, grafik, televise, computer agar kegiatan pembelajaran lebih menyenangkan dan peserta didik dapat menyerap dan menangkap pelajaran dengan baik.

Media pembelajaran adalah tuntutan yang harus dipenuhi dalam rangka meningkatkan kualitas dan profesionalisme guru. Ditangan guru yang profesional dalam mengembangkan pelajaran akan menghasilkan pembelajaran PKn yang berkualitas. Dengan mengembangkan metode dan media pembelajaran PKn diharapkan akan muncul proses pembelajaran yang menyenangkan dan tidak membosankan. Media pembelajaran mempunyai beberapa fungsi, diantaranya : 1.) Media 
pembelajaran sebagai alat bantu dalam pembelajaran.

Pada satu sisi ada materi ajar yang tidak memerlukan alat bantu, tetapi di lain pihak ada materi ajar yang sangat memerlukan alat bantu, 
tetapi di lain pihak ada materi ajar yang sangat memerlukan alat bantu berupa media pembelajaran. Media pembelajaran yang dimaksud antara lain berupa globe, grafik, gambar, dan sebagainya.

2.) Media pembelajaran sebagai sumber belajar.

Sumber belajar adalah segala sesuatu yang dapat dipergunakan sebagai tempat bahan pembelajaran untuk belajar peserta didik tersebut berasal. Sumber belajar dapat dikelompokkan menjadi lima katagori, yaitu manusia, buku perpustakaan, media massa, alam lingkungan, dan media pendidikan.

Media pembelajaran mempunyai beragam macam. Tetapi guru tidak akan menggunakan seluruh media pembelajaran tersebut secara bersamaan. Tetapi guru akan memilih media pembelajaran yang cocok yang akan digunakan dalam materi yang akan ia sampaikan. Agar pemilihan media pembelajaran tersebut tepat, maka perlu dipertimbangkan faktor atau kriteria- kriteria dan langkah-langkah pemilihan media pembelajaran

Kriteria pemilihan media pembelajaran yang baik yang perlu diperhatikan antara lain : 1) ketepatan tujuan dalam pembelajaran, 2) dukungan terhadap isi pelajaran yang disampaikan, 3) kemudahan pengajar 
dalam memperoleh media pembelajaran, 4) keterampilan guru dalam menggunakan media 
pembelajaran, 5) tersedianya waktu untuk penggunaan, dan 6) sesuai dengan taraf berpikir peserta didik. (Sudjana dan Rivai,2009)

Maksud dari pendapat diatas akan diuraikan sebagai berikut :

A. Ketepatan tujuan dalam pembelajaran.

Ketika dalam pemilihan media pembelajaran hendaknya dipilih yang dapat menunjang pencapaian tujuan pembelajaran yang telah ditetapkan. Pilihlah media pembelajaran yang cocok digunakan dalam materi yang diajarkan agar peserta didik mampu memahami apa yang disampaikan oleh pengajar.

B. Dukungan terhadap isi pelajaran yang disampaikan oleh pengajar.

Media pembelajaran sangat dibutuhkan oleh guru ketika guru dalam menyampaikan materi dengan bahan pelajaran yang bersifat fakta, prinsip dan konsep agar peserta didik dapat memahami materi yang disampaikann oleh guru.Selain itu Media pembelajaran yang dipilih oleh guru untuk kegiatan mengajar hendaknya sesuai dengan materi yang diajarkan. Jika tidak sesuai dengan materi yang diajarkan maka akan sia-sia dalam menggunakan media pembelajaran, sebab peserta didik tidak akan paham dengan 
maksud yang diterangkan atau dijelaskan oleh guru.

C. Kemudahan pengajar dalam memperoleh media pembelajaran. 
Guru dalam memperoleh media pembelajaran bisa dengan mudah membuat media yang akan digunakan. Membuat sebuah media pembelajaran bisa dari bahan-bahan bekas lalu didaur ulang menjadi media, bisa juga membuat media pembelajaran bersama peserta didik, jadi peserta didik juga dapat menumbuhkan sikap kreatifitasnya, bisa juga dengan membeli atau meminjam.

D. Keterampilan guru dalam menggunakan media pembelajaran.

Guru dalam memilih media pembelajaran juga harus pintar dalam penggunaannya agar media tersebut akan memberikan manfaat bagi peserta didik dalam proses belajar mengajar. Jadi ketika dalam mengajar dengan menggunakan media, guru bisa menggunakannya dengan baik.

E. Tersedianya waktu untuk penggunaan.

Guru dalam penggunaan media pembelajaran juga harus memikirkan waktu pada penggunaan media pembelajaran tersebut. Karena penggunaan waktu akan mempengaruhi guru dalam menggunakan media.Untuk itu ketika memilih media pembelajaran guru juga harus memikirkan waktu yang tersedia cukup untuk penggunaan medianya.

F. Penyesuaian dengan taraf berpikir peserta didik. Sebagai guru memilih media pembelajaran 
juga harus memikirkan apakah media pembelajaran yang akan digunakan cocok untuk karakteristik atau taraf berpikir peserta didik. Memilih media 
pembelajaran juga perlu adanya pertimbangan seperti media yang akan digunakan oleh guru cocoknya untuk jenjang pendidikan yang mana dan apakah media tersebut apakah cocok dengan gaya belajar mereka.

Dalam penggunaan media pembelajaran yang akan guru gunakan, perlu adanya langkah-langkah dari media pembelajaran tersebut agar media yang telah dipilih oleh guru dapat digunakan secara efektif dan efisien. Berikut 3 (tiga) langkah pokok yang dilakukan oleh guru :

A.) Persiapan.

Guru dalampenggunaan media pembelajaran harus ada persiapan. Persiapan yang dapat dilakukan oleh guru adalah sebagai berikut :

a) Membuat RPP sebagaimana ketika akan mengajar seperti biasanya. Dalam rencana pelaksanaan pembelajaran cantumkan media yang akan digunakan,

b) Mempelajari buku petunjuk,

a. Menyiapkan dan mengatur peralatan yang akan digunakan agar dalam pelaksanaannya nanti tidak terburu-buru dan mencari-cari lagi serta peserta didik dapat melihat dan mendengar dengan baik.

B.) Pelaksanaan atau Penyajian.

Guru perlu bebrapa pertimbangan ketika akan 
memulai menggunakan media pembelajaran yaitu dengan meyakinkan bahwa media dan peralatan yang akan digunakan sudah lengkap serta siap akan digunakannya. Guru juga harus menjelaskan tujuan yang akan dicapai dari pembelajaran ini dan hindari 
kejadian yang menggangu konsentrasi belajar peserta didik.

C.) Tindak lanjut.

Kegiatan tindak lanjut perlu dilakukan oleh guru karena untuk memantapkan pemahaman peserta didik apakah mereka paham apa yang dipelajari dengan menggunakan media pembelajaran. 


\section{KESIMPULAN}

Penggunaan metode dan media yang cocok sangatlah di perlukan untuk membantu sekaligus mempermudah dalam proses pembelajaran. Sesuai dengan karakteristik anak SD dan seusianya, metode ceramah akan menyebabkan siswa bersikap pasif dan tentunya menjadi pelajaran hafalan yang membosankan. Oleh karena itu, guru di harapkan mampu menguasai metode-metode dan media yang cocok untuk pembelajaran PKN agar siswa lebih tertarik pada pelajaran tersebut.Selain itu guru juga di harapkan mampu menerapkannya dalam pembelajaran sehari - hari.

Ada banyak contoh metode yang cocok dan dapat di gunakan dalam proses pembelajaran terutama pelajaran pkn di sd. Di antaranya yaitu Metode Ceramah, Metode Cerita, Metode Tanya Jawab, Metode Penugasan, Metode Permainan atau Kompetisi. Dan dalam mengaplikasikan metode ada baiknya guru juga menggunakan media dalam proses pembelajaran. Media di sini dapat menjadi alat bantu guru dalam menjelaskan materi selain itu media juga bisa sebagai sumber belajar siswa. Dengan metode dan media yang cocok di gunakan saat pembelajaran, maka proses belajar mengajar dapat terlaksana secara maksimal selain itu siswa akan bisa lebih mudah menerima materi yang di ajarkan sehingga hasil belajar siswa maksimal. 


\section{BAB 5}

Pengembangan Lks Pkn / Worksheet Yang Berbasis Aktivitas Yang MengandungPengalaman Belajar Yang Bermakna

CP-MK Capaian Pembelajaran Mata Kuliah :

A. Mahasiswa dapat memahami KarakteristikLKS pada level pembelajaran SD

B. Mahasiswa dapat mendeskripsikan Penyesuaian Lks Sesuai Dengan KarakterSiswa

C. Mahasiswa dapat menganalisis Lks / Worksheet Pkn BerbasisAktivitas

D. Mahasiswa dapat menganalisis Lks / Worksheet Pkn Berbasis Pengalaman BelajarBermakna

E. Mahasiswa dapat mengaplikasikan Pengembanganbahan Ajar PKn di SD

F. Mahasiswa dapat mendeskripsikan Implikasi Lembar Kerja Siswa / DalamPembelajaran

\section{A. Karakteristik Lembar Kerja Siswa (LKS)}

Lembar kerja siswa (LKS) merupakan lembar kegiatan bertujuan untuk membantu dan mempermudah dalam proses pembelajaran berlangsung. Jadi, dapat dikatakn LKS merupakan sarana alternatif yang akan membentuk interaksi dalam proses pengajaran yang efektif antara tenaga pendidik dan peserta didik. Sehingga diharapkan mampu meningkatkan aktivitas siswa dalam meraih 
peningkatan hasilbelajar. 
DinyatakanLembar Kerja Siswa (LKS) bagi siswa adalah baik dalam kegiatan intrakurikuler maupun kokurikuler dapat membantu siswa atau sebagai alat bahan ajar untuk peserta didik dalam memahami materi yang diajarkan dan Lembar kerja siswa pun juga dapat mempermudah pemahaman siswa terhadap materi yang diajarkan oleh gurunya. Oleh (Azhar, 1993:78).

Jadi, LKS ataupun workshet merupakan lembaran aktivitas siswa yang didalamnya terdapat informasi informasi dan petunjuk dari tenaga pendidik kepada pserta didik guna mengerjakan secara individu dalam kegiatan belajar dan praktek, mengerjakan tugas yang lainnya yang sesuai dengan mater pembelajaran berlangsung guna untuk mencapinya tujuan pembelajaran berlangsung. Adapun tujuan Lembar Kerja Siswa atau Worksheet yang dapat menjadi acuan untuk membuat sebuah lembar aktivitassiswa.

Dinyatakan LKS dibuat bertujuan untuk menuntun siswa berbagai kegiatan yang perlu diberikan serta dapat mempertimbangkan proses berfikir yang ada dalam diri peserta didik serta lembar kerja siswa juga mempunyai fungsi sebagai urutan kerja yang diberikan dalam kegiatan intrakulikuler ataupun ekstrakulikuler sehingga materi dapat tersampaikan melalui LKS dengan baik dan mudah dimengerti bagi peserta didik dalam pemahamanmaterinya.

Oleh 
(Azhar1993:78) 
Berdasarkan kutipan diatas, bahwa lembar kerjas siswa maupun worksheet memiliki tujuan pengerjaan yang jelas sesaui dengan tujuan pembelajaran berlangsung, agar tidak melenceng dari tujuan pembelajaran berlangsung. Sehingga sesuai dengan tujuan pembelajaran berlangsung. Lembar kerja siswa yang disajikan kepada peserta didik merupakan materi yang telah disampaikan oleh tenaga pendidik pada kegiatan belajar mengajar berlangsung. Untuk lembar kerja siswa aktif , maka lembar kerja tersbut didesain sesuai dengan aktivitas siswa berdasarkan karakteristik siswa. Sehingga lembar kerjasiswatersebutdapatmembantumeningkatkankogniti fda npsikomotoriksiswa.

\section{B. Penyesuaian LKS sesuai Berdasarkan KarakterSiswa}

Terdapat beberapa tahapan yang berkaitan dengan usia dan cara berpikir yang berbeda, yang di temukan oleh Teori Piaget. Teori Piaget diciptakan oleh Jean Piaget yang merupakan pakar psikologi dari Negara Swiss pada tahun 1896 - 1980. Ada beberapa tahapan Menurut Piaget (1896 - 1980) adalah tahap sensorimotor ; tahap praoperasional ; tahap operasional konkret ; tahap operasional formal. Namun, penulis mebahas tentang tahap praoperasional dan tahap operasionalkonkret.

"Tahap Praoperasional dimulai dari usia 2 sampai 7 tahun. Anak mulai merepresentasikan 
dunia dengan kata - kata dan gambar. Kata kata dan gambar ini mencerminkan pemikiran yang simbolik, yang semakin maju dan melampaui hubungan informasi sensori dan tindakan fisik. Tetapi pemikiran 
operasional belum ada. Tahap Operasional Konkret di mulai dari usia 7 sampai 11 tahun. Anak mulai berpikir dengan logis dan mengklarisifikasikan objek ke dalam kategori yang berbeda. Dikemukakan oleh (Piaget, 1896 - 1980 : 50, karangan Santrock, John W. Psikologi Pendidikan)"

Dalam kutipan diatas bahwa, tahap praoprasional dapat dikatakan dimulai dari usia balita, taman kanak kanak (TK) hingga sekolah dasar (SD) kelas 1. Namun pada usia kelas 1 yaitu 7 tahun merupakan masa transisi dimana peserta didik dari dunia taman kanak kanak (TK) ke dunia sekolah dasar. Pada usia sekolah dasar, anak - anak sudah bisa mendeskripsikan secara simbolik dengan benar. Untuk mengerjakan lembar kerja siswa pada usia sekolah dasar cenderung berdasarkan pengetahuan yang dimilikinya. Pada tahap operasional konkret yaitu dimulai dari usia sekolah dasar yaitu 7 hingga 11, yang dimana usia tersebut dimulai pada kela 1 sampai kelas 5 . Operasi konkret merupukan sautu tindakan mental yang menimbulkan hubungan timbal balik dan berkaitan dengan benda nyata. Pada tahap ini anak secara kondisi mental mampu mengerjakan apa yang sebelumnya dapat dilakukan secara fisik dan mereka mampu mengembalikan operasi yang konkret.

Dalam karekteristik siswa di sekolah dasar, di bagi menjadi dua yaitu karakter siswa kelas rendah dan karakteristik siswa kelas tinggi. Yang biasanya dapat 
disebut kelas awal dan kelas tinggi. Kelas awal terdapat di kelas 1, 2 dan 3, sedangkan kelas tinggi terdapat di kelas 4,5 dan6. 
"Masa kelas rendah sekolah dasar, beberapa sifat khas anak pada usia ini antara lain : (a) adanya korelasi positif yang tinggi antara keadaan kesehatan pertumbuhan jasmani dengan prestasi sekolah, (b) kalau tidak dapat meyelesaikan sesuatu soal, maka soal itu di anggap tidak penting, (c) pada masa ini (terutama umur 6-8) anak menghendaki nilai (angka rapor) yang baik, tanpa mengingat apakah prestasinya memang pantas diberi nilai baik buruk. Masa kelas tinggi sekolah dasar, beberapa sifat khas anak pada masa ini sebagai berikut : (a) adanya minat terhadap kehidupan praktis setiap hari yang konkret, hal ini menmbulkan adanya kecenderungan untuk membandingkan pekerjaan - pekerjaan yang praktis,

(b) amat realistik, ingin tahu dan ingin belajar, (c) pada masa ini anak gemar membentuk kelompok sebaya, biasanya untuk dapat bermain bersama sama. Di dalam permainan ini biasanya tidak lagi terikat pada aturan permainan yang tradisional, mereka membuat peraturan sendiri." (karangan Maliki. Bimbingan konselenig Di Sekolah dasar Suatu Pendekatan Imajinatif.)

Dari kutipan diatas, hal tersebut nampak berbeda, karena setiap kelas memiliki ciri khas masing - masing, sehingga setiap kelas memiliki ciri khas karakteristik siswa. Pada kelas awal karakteristik yang menonjol yaitu pada poin b, yang dimana jika tidak 
dapat menyelesaiak sebuah soal, maka soal tersebut dianggap tidak penting. Jadi, untuk membuat workhseet atau lembar kerja siswa hendaknya melihat ciri khas siswa dan 
melihattingkatkesulitankatakerjaoperasionalpadatingkatan kelasrendahtersebut.

Sedangkan, di keals tinggi karakteristik yang sering muncul pada anak yaitu pada poin dimana pada poin $\mathrm{b}$ tersebut, peserta didik memiliki rasa ingin tahu lebih tinggi. Karena memiliki rasa penasaran dan selalu bertanya untuk menambah wawasan mereka, sehingga ingin belajar juga tinggi karena adanya keterhubungan dengan rasa ingin tahu. Untuk lembar kerja siswa sama halnya dengan pada kelas awal. Namun pada kelas tinggi ini memiliki tingkat kesukaran yang tingi berdasarkan levelnya. Sehingga, pengetahuan yang dimiikinya semakinbertambah.

Begitu juga dengan lembar kerja siswa / worksheet pun berbeda. Karena setiap kelas memiliki tingkat kesulitan yang berbeda. Tingkat kesulitan belajar siswa dalam mengerjakan soal terdapat pada kata kerja operasional yang akan digunakan, yang di kemukakan oleh Bloom sering disebut teori taksnomibloom.

\section{LKS / Worksheet PKN BerbasisAktivitas}

Tujuan dari pembuatan LembarKerjaSiswa (LKS) / worksheet adalah untuk mengambangkan perangkat pembelajaran mata pelajaran PKN berbasis aktivitas. Dan ada pun perangkat pembelajaran tersebut dapat meliputi: silabus, RPP, LKS, dan Bahan Ajar Siswa (BAS). 
1. Pengembangan perangkat pembelajaran

Pengembangan perangkat pembelajaran ini menggunakan model Dick \&Cerey. Untuk meningkatkan 
pada ketentuan dan kebutuhan dalam mata pelajaran PKN terutama LKS/Worksheet PKN berbasis aktivitas.

"Dinyatakan Pengembangan perangkat merupakan suatu lingkaran yang kontinum. Tiap - tiap langkah pengembangannya peserta didik dapat langsung dengan aktifitas. Pengembangan perangkat pembelajaran ini dapat memberikan kesempatan untuk mengembangkan komponen dapat dimulai darimana pun sehingga kurikulum pembelajaran yang berlaku disekolah atau secara nasional pengembangannya dimulai dari tujuannya. Oleh (Trianto, 2007:53)"

"Dinyatakan Perancangan pengajaran menurut sistem pendekatan model Dick \& Cerey, yang dikembangkan oleh Walter Dick \& Lou Carey. Model pengembangan ini juga hamper sama dengan pernyataan diatas oleh karena itu dapat ditambahkan dengan komponen analisis pembelajaran yang didalamnya terdapat beberapa komponen proses pengembangan dan perencanaan tersebut dalammenyusunlembarkerjasiswayangberbasis aktif. Oleh(Trianto,2007:61)". 
Untuk memperkuat kutipan diatas pengembangan perangkat pembelajaran sangatlah perlu diperhatikan dalam pelaksanaan proses belajar mengajar. Sehingga sekolah- sekolah yang ada dapat menyesuaikan kurikulum 
yang digunakan didalam sekolah tersebut. Sehingga dapat memfasilitasi Lembar KerjaSiswa / worksheet yang berbasis aktif untuk peserta didiknya, agar peserta didik tersebut dapat berfiir kritis dalam pembelajaran Pendidikan Kewarganegaraan dan dapat memberikan bekal untuk peserta didik dimasa yang akan datang. Dan selanjutnya pengembangan perangkat pembelajaran dilakukan sebagaiberikut:
a. Mengidentifikasitujuan
b. Menganalisispembelajaran
c. Menganalisissiswa
d. Merumuskan tujuanpembelajaran
e. Menyusun tes beracuancriteria
f. Mengembangkan strategipembelajaran
g. Memilih media pembelajaran
h. Mengembangkan perangkatpembelajaran
i. Melaksanakan validitas

\section{LKS / Worksheet PKN Berbasis \\ Pengalaman BelajarBermakna}

Dalam pengalaman bermakna tentunya diimbangi dengan pembelajaran yang aktif. Pembelajaran yang aktif akan menimbulkan pengalaman belajar yang bermakna. Sehingga pembelajaran yang aktif dan pengalaman belajar bermakna memiliki keterhubungan. Dalam pembelajaran aktif dan pengalaman belajar yang bermakna akanmeingkatan kognitif dan hasil belajr siswa 
Ranah penilaian memang terdiri atas 3 ranah 
yaitu kognitif, afektif, dan psikomotor. sedangkan disini menurut judul yang kami terima yaitu memfokuskan pada penyusunan lembar kerja siswa PKN/ worksheet yang bebbasis aktivitas yang mengandung pengalaman bermakna. Di judul kami juga tertulis LKS berbasis aktif dan pengalaman bermakna itu juga dapat di masukkan sebagai ranah kognitif danpsikomotor

"Dalam pembelajaran aktif merupakan suatu model pembelajaran yang memberikan kesempatan kepada peserta didik untuk aktif membangun sendiri konsep dan makna melalui kegiatan. Dalam pembelajaran aktif siswa yang harus di tuntut aktif sedangkan guru hanya sebagai menjadi fasilitator. (Warsono \& Hariyanto, $2014: 20$ ).

Dalam kutipan diatas, merupakan dampak dari pengalaman belajar bermakna bagi siswa. Karena peserta didik di tuntuk aktif dan mencari sendiri, sehingga memuncul nilai karakter siswa yaitu beranai untuk mencari sebuah informasi. Untuk worksheet seperti lembar observasi. Yang dimana siswa untuk mancari informasi dari buku maupun dari sumber yang lainnya, sehingga pengalaman belajar siswa meningkatkan. Namun tenaga pendidik harus kreatif dalam mendesain worksheet atau lembar kerja siswa guna untuk 
menimbulkan pengalaman belajar siswa yang aktif dan bermakna. Guru mendesain lembar kerja siswa pada mata pelajaran hendaknya melihat tiga komponen yang dimiliki dalam pendidikan PKn. Tiga 
komponen tersebut yaitu civic knowledge (membahas seputar tentang pengetahuan), cvic skill (membahas tentang kecakapan kewarganegaraan)dan civic disposition

(membahas tentang watakkewarganegaraan).

\section{E. Pengembangan Bahan Ajar}

Bahan ajar tidak hanya berupa LKS saja. Bahan ajar juga dapat terdiri dari buku paket BSE, dan LKS hanya melengkapi untuk peserta didik agar dapat lebih luas mengetahui materi yangdipelajarinya

"Bahan ajar merupakan informasi, alat dan teks yang diperlukan guru atau instruktur untuk perencanaan dan penelaahan implementasi pembelajaran. Bahan ajar adalah segala bentuk bahan yang digunakan untuk membantu guru atau instruktur dalam melaksanakan kegiatan belajar mengajar didalam kelas. Bahan yang dimaksud bias berupa bahan tulisan maupun bahan tidak tertulis" Nationa ICenter for Vocational Education Research Ltd/National Center for Competency Besed Training dalam Depdiknas2007:3)."

Jadi bahan ajar merupakan sumber informasi tambahan untuk peserta didik guna untuk menambah wawasan sehingga pengetahuan yang didapat 
bertambah. Bahan ajar digunakan oleh guru sebagai untuk membantu penyampaian perencanaan pembelajaran berlangsung serta tercapainya tujuan pembelajaran. 
Dari penjelasandiatasmateri

yang terdapatdalambahan ajar diharapkan dapat dipelajari siswa sebagai sarana untuk mencapai standar kompetensi dan kompetensi dasar. Materi tersebut menunjuk pada ranah kognitif, afektif, dan psikomotor. Dan pengertian diatas agar bahan ajar dapat berfungsi dengan baik maka harus berciri cirisebagai berikut : (a) Menimbulkan minat baca, (b) Di tulis dan dirancang untuk siswa, (c) Menjelaskan tujuan instruksional, (d) Disusun berdasarkan pola belajar yang fleksibel struktur berdasarkan kurikulim siswa, (f) Memberi kesempatan untuk siswa berlatih, (g) Memberikan rangkuman, dan (h) Kepadatan berdasarkan kebutuhan siswa. Tiga komponen pendidikan kewarganegaraanyaitu "civic knowledge, cvic skill dan civic disposition" dari tiga hal tersebut dapat dijelaskan sebagaiberikut:

Civic skill (kecakapan kewarganegaraan) yang meliputi kecakapan intelektual dan kecakapan pertisipatoris. Kecakapan intelektual kewarganegaraan merupakan kemampuan mendiskripsikaanya itu mendiskripsikan fungsi - fungsi dan proses-proses seperti cheks and balances atau judicial review menunjukkan adanya pemahaman, sedangkan kecakapan prtisipatoris merupakan kecakapan yang berupa partisipasi yang 
beertanggungjawab, efektif,danilmiahdalamprosespolit ikd andalamcivilsociety.

Civic disposition (watak

kewarganegaraan) merupakan karakter public

maupun privat yang penting 
bagi pemeliharaan dan pengembangan demokrasi konstitusional. Watak kewarganegaraan sebagaimana kecakapan kewarganegaraan, berkembang secara perlahan sebagai akibatdariapa yang telah dipelajari dan dialami dirumah, disekolah, dan oraganisasi - organisasi civilsociety.

Jadi dapat di simpulkan bahwa bahan ajar PKN maupun LKS PKN adalah seperangkat materi PKN yang mengandung civic knowledge, civic skill, dan civic disposition yang disusun secara sistematis baik tertulis maupun tidak sehingga dapat tercipta lingkungan atau suasana yang memungkinkan siswa untuk belajar.

\section{F. Implikasi Lembar Kerja Siswa / DalamPembelajaran}

Adanya penyediaan alat lembar kerja siswa maupun worksheet mampu menjadikan peserta didik lebih aktif, cepat tanggap dan juga kreatif. Namun di sisi lain lembar kerja menjadikan pengalaman siswa yang aktif dan bermakna. Tujuan adanya lembar kerja dapat mengetahui kognitif, afektif serta psikomotoriksiswa.

"Pendekatan keterampilan proses pada hakikatnya adalah suatu pengelolaan kegiatan belajar-mengajar yang berfokus pada pelibatan siswa secara aktif dan kreatif dalam proses pemerolehan hasil belajar (Semiawan, 1992)."

Adapun pendekatan yang digunakan yaitu 
pendekatan keterampilan proses. Peserta didik dilatih untuk mencari dan mengumpulkan ide maupun konsep sebanyak mungkin terkait dengan materi dalam kegiatan belajar berlangsung yang akan di pelajari dan di 
diskusikan melalui LKS atau worksheet bertujuan untuk memperoleh hasil kesimpulan.

LKS dapat dijadikan sebagai alat bantu atau disebut sebagai media pembelajaran yang dapat dilakukan dengan optimal, sebagai sumber informasi tambahan dan juga sebagai kumpulan latihan latihansoal. 
BAB 6

Perancangan Program Kegiatan Siswa Di Sekolah

Yang Berbasis Aktivitas Yang Mengandung

Pengalaman Belajar Yang Bermakna Guna

Menciptakan Perilaku Berkarakter

\section{CP-MK Capaian Pembelajaran Mata Kuliah :}
A. Mahasiswa dapat memahamiKonsep Pendidikan Karakter
B. Mahasiswa dapat mendeskripsikan Pendidikan Karakter Di Sekolah
C. Mahasiswa dapat menganalisis Peran Strategis Kegiatan Ekstrakulikuler Sebagai Pembentuk Karakter
D. Mahasiswa dapat mendeskripsikan Contoh Program Sekolah di level SD

A. Konsep Pendidikan Karakter

Pendidikan adalah suatu proses untuk membantu menumbuhkan, mengembangkan, dan bahkan menciptakan sesuatu yang tidak teratur menjadi teratur seperti proses membuat tatanan dan keteraturan pada diri seseorang. Seseorang yang pada awalnya kurang memiliki tatanan dan keteraturan pada dirinya atau bahkan tidak ada sama sekali tatanan dan keteraturan pada dirinya itu pada waktunya nanti dirinya akan menjadi tertata dan teratur karena adanya suatu proses yang dijalaninya dalam pendidikan. Selain itu pendidikan juga sebuah 
pengembangan potensi-potensi yang dimiliki seseorang.

Melalui proses yang terdapat di dalam pendidikan, segala bentuk potensi diri sesorang seperti kemampuan berpikir, pengetahuan, kemampuan bersosialisai, 
kemampuan fisik, nilai-nilai kebaikan, talenta, ataupun daya seni akan digali, diarahkan, dan dikembangkan.Sebenarnya, pendidikan tidak hanya mengunggulkan prestasi akademik saja melainkan juga harus memperhatikan pembentukan karakter anak bangsa. Beberapa tahun belakangan ini, karakter anak-anak bangsa sudah sangat merosot dalam artian terdapat kerusakan yang terjadi pada akhlak, pemahaman nilai-nilai kebangsaan, dan perilaku yang diperbuat oleh generasi muda yang melampaui batas. Oleh karena itu, pembentukan karakter saat ini menjadi prioritas untuk membangun kembali karakter bangsa Indonesia.

Pendidikan bertujuan untuk pembangunan atau pembentukan karakter dapat mencakup pengembangan substansi, proses dan suasana atau lingkungan yang menggugah. (yang kami kutip dari dalam buku Mendesain Sekolah Unggul yang dikarang oleh Dr. HM. Musfiqon, M.Pd pada halaman 108)

Sebenarnya ada banyak cara yang bisa dilakukan untuk membentuk karakter anak bangsa, salah satu caranya adalah dengan adanya pendidikan karakter. Pendidikan karakter merupakan sesuatu yang harus atau benar-benar dilakukan sebagai bagian dari upaya atau usaha untuk membangun karakter bangsa.Karena pembentukan karakter memberikan dukungan dan dapat memudahkan siswa 
dalam mengembangkan karakter baik yang akan menjadi kebiasaan baik dalam kehidupan sehari- hari. Arti kata karakter yaitu segala hal mengenai sifat- 
sifat, akhlak, dan watak yang ada di dalam diri seseorang yang berbeda dengan orang lain yang dicerminkan melalui pemikiran, perkataan, dan tingkah laku orang tersebut.

Karakter ialah tabiat, watak, sifat-sifat kejiwaan, akhlak, atau budi pekerti yang membedakan seseorang daripada yang lain. Karakter adalah sifat utama yang terukir, baik pikiran, sikap, perilaku, maupun tindakan yang melekat dan menyatu kuat pada diri seseorang, yang membedakannya dengan orang lain. (yang kami kutip dari dalam jurnal penelitian Membangun Karakter Siswa Melalui Kegiatan Intrakurikuler, Ekstrakurikuler, dan Hidden Curriculum oleh Prawidya Lestari dan Sukanti STAINU Purworejo, Jawa Tengah)

Berdasarkan pengertian karakter di atas, sebenarnya kita dapat melihat karakter yang dimiliki seseorang dalam dua hal yaitu yang pertama adalah sesuatu yang telah ada begitu saja atau memang sudah ada dari sananya. Dan yang kedua adalah sesuatu yang timbul sebagai akibat dari suatu proses yang dijalani. Sehingga dapat disimpulkan bahwa karakter merupakan kumpulan nilai yang terbentuk di dalam diri seseorang melalui proses pendidikan, pengaruh dari lingkungan, pembiasaan, atau bahkan pengalaman yang didukung dan digabungkan dengan kumpulan nilai yang telah ada dalam dirinya sebagai 
landasan tindakannya, perilakunya, pemikirannya, dan sikapnya.

Pendidikan karakter tidak hanya mengajarkan mana yang salah dan mana yang benar saja. Tetapi 
pendidikan karakter juga sebuah upaya dalam menanamkan kebiasaan-kebiasaan yang baik pada siswa, yang nantinya siswa akan dapat berperilaku dan bersikap sesuai nilai-nilai yang sudah menjadi bagian dari kepribadiannya. Sehingga dapat dikatakan bahwa pendidikan karakter yang baik pasti melibatkan pengetahuan yang baik (moral knowing), perasaan yang baik (moral feeling), dan perilaku yang baik (moral action) yang nantinya akan membentuk implemntasi kesatuan perilaku dan sikap hidup yang baik pada siswa.

Pendidikan karakter yang baik harus melibatkan bukan saja aspek pengetahuan yang baik (moral knowing), tetapi juga merasakan dengan baik atau loving the good (moral feeling) dan perilaku yang baik (moral action). (yang kami kutip dari buku Pembelajaran Membaca Berbasis Pendidikan Karakter yang dikarang oleh Yunus Abidin, M.Pd halaman 34)

Seseorang dapat dikatakan atau dicap dirinya sebagai seseorang yang berkarakter apabila telah mempunyai dan menunjukkan atau mengimplementasikan ketiga ranah (domain) besar karakter yang ia miliki dalam kehidupannya sehari-hari seperti diatas. Ketiga ranah besar tersebut beserta unsur-unsurnya diantaranya adalah sebagai berikut : 
1. Pengetahuan tentang moral / pengetahuan yang baik (moral knowing) 
a. Apabila seorang manusia dengan sadar telah memiliki pengetahuan dan pemahaman mengenai hal-hal manakah yang dianggap atau dinilai baik dalam masyarakat dan hal-hal manakah yang dianggap atau dinilai tidak baik dalam masyarakat, merupakan suatu pengertian atau definisi dari kesadaran moral.

b. Apabila seorang manusia sudah mengetahui dan memahami tentang apa-apa sajakah yang termasuk ke dalam tipe-tipe nilai moral yang dikategorikan sebagai nilai moral yang baik dan nilai moral yang tidak baik. Kategori nilai moral yang baik yaitu contohnya adalah saling menghargai, ulet, jujur, dan lain sebagainya. Sedangkan kategori nilai moral yang tidak baik contohnya yaitu pemalas, menyukai kekerasan, pembangkang, dan lain sebagainya. Penjabaran yang telah dituliskan tersebut diatas merupakan pengertian atau makna dari pengetahuan tentang nilai moral.

c. Apabila seseorang telah mampu untuk mengetahui maksud dari pemikiran orang lain, mampu ikut merasakan sesuatu yang dirasakan oleh orang lain, mampu memahami maksud dari perilaku atau perbuatan yang dilakukan oleh orang lain serta mampu untuk menempatkan dirinya seolah-olah sebagai orang lain tersebut merupakan pengertian mengenai pengambilan perspektif. 
d. Apabila seseorang telah memiliki kepedulian dan memahami mengenai hal-hal apa sajakah yang 
disebut sebagai moral dan hal-hal apa sajakah yang menjadi landasan ataupun alasan adanya moral tersebut merupakan definisi dari keberalasan moral. Namun seseorang tersebut haruslah memiliki kemampuan untuk mengetahui makna atau maksud yang utama dari setiap tipe-tipe nilai moral, baik tipe nilai moral yang dikategorikan baik maupun tipe moral yang dikategorikan tidak baik.

e. Pengambilan keputusan adalah apabila seorang manusia sudah memiliki keahlian dalam mengambil suatu keputusan sebagai suatu solusi atau jalan keluar dalam permasalahan yang sedang dihadapi dengan penuh perhitungan dengan harapan bahwa keputusan yang diambil itu tepat dan yang terbaik.

f. Seorang dikatakan mempunyai pemahaman diri apabila ia telah memiliki kemampuan untuk memahami dirinya sendiri, memahami tentang hal- hal manakah yang disukai, hal-hal manakah yang tidak disukai, yang selanjutnya ia juga mampu mengendalikan atau mengontrol dirinya untuk tidak melakukan perbuatan yang tidak baik dan memberi semangat bagi dirinya sendiri untuk selalu melakukan perbuatan yang baik.

2. Perasaan moral / perasaan yang baik (moral feeling)

a. Apabila seorang manusia yang menyadari mengenai moral yang ada dalam dirinya itu 
dapat dikatakan baik dengan landasan ilmunya, pengetahuannya, serta perasaannya merupakan definisi dari kesadaran. 
b. Apabila seseorang telah mempunyai rasa percaya diri dalam dirinya, mempunyai keyakinan bahwa ia mampu melakukan sesuatu dengan kekuatan dan kemampuannya sendiri tanpa harus selalu mengandalkan kekuatan atau kemampuan orang lain maka ia dapat dicap sebagai seorang yang berkarakter, hal tersebut merupakan definisi dari percaya diri.

c. Apabila seorang manusia dimana di dalam dirinya telah ada suatu perasaan kepedulian (respect) terhadap orang-orang disekitarnya maka ia dapat dicap sebagai seorang yang berkarakter, hal tersebut merupakan definisi dari empati.

d. Apabila seorang manusia secara sadar mencintai kebaikan dan selalu berusaha untuk mengaplikasikan kebaikan dalam kehidupannya sehari-hari maka ia dapat dicap sebagai seorang yang berkarakter, hal tersebut merupakan pengertian dari mencintai yang baik.

e. Apabila sseorang manusia mempunyai kemampuan untuk memgendalikan emosionalnya serta meluapkan emosionalnya ke dalam hal-hal yang positif maka ia dapat dicap sebagai seorang yang berkarakter, hal tersebut merupakan pengertian dari kontrol diri.

f. Apabila seorang manusia secara terbuka 
dapat menerima hal-hal yang dinilai benar serta mengakui kesalahanmya dan berusaha memperbaikinya maka ia dapat dicap sebagai seorang yang berkarakter, hal tersebut merupakan pengertian dari kerendahan hati. 
3. Aksi moral / perilaku yang baik (moral action)

a. Apabila seorang manusia bisa menerapkan keputusan yang diambilnya sebagai solusi untuk memecahkan masalahnya serta menerapkan perasaan moral yang ada pada dirinya dalam perwujudan perilaku yang baik merupakan pengertian dari kompetensi.

b. Apabila seorang manusia dapat mewujudkan keinginannya dalam berbagai bentuk perilaku di kehidupannya dengan tetap pada batas-batas nilai moral yang berlaku merupakan makna dari keinginan.

c. Apabila seorang manusia dalam dirinya sudah terbentuk kebiasaan untuk berbuat maupun berperilaku yang sesuai dengan nilai moral merupakan makna dari kebiasaan.

Karakter seseorang merupakan suatu perpaduan antara nilai-nilai bawaan atau turunan sejak lahir yang ada pada dirinya dan nilai-nilai yang terbentuk karena adanya proses pendidikan. Jadi karakter dapat dibentuk sejak dini melalui pendidikan karakter, baik dalam pendidikan formal, pendidikan informal, maupun pendidikan nonformal dengan enam dasar. Keenam dasar tersebut, diantaranya adalah :

1. Pembiasaan (habituasi) yang baik

Dalam pembiasaan (habituasi) ini, sesuatu 
yang perlu dibiasakan haruslah dimulai dari adanya niat yang baik, berpikir yang baik, berkeyakinan yang baik, 
berperasaan yang baik, dan mewujudkannya dalam perbuatan atau perilaku yang baik pula.

Salah satu penyebab ketidakmampuan sesorang berlaku baik, meskipun ia telah memiliki pengetahuan tentang kebaikan itu, adalah karena ia tidak terlatih (terbiasa).

(yang kami kutip dari dalam jurnal penelitian Membangun Karakter Siswa Melalui Kegiatan Intrakurikuler, Ekstrakurikuler, dan Hidden Curriculum oleh Prawidya Lestari dan Sukanti STAINU Purworejo, Jawa Tengah).

2. Berpengetahuan dan berpemahaman tentang hal-hal yang baik (knowing the good).

Dalam hal ini, perlu dilakukan pemberian pengetahuan dan pemahaman tentang hal-hal yang baik dari suatu kebaikan tersebut terlebih dahulu agar seseorang mengetahui dan memahami hal-hal yang baik dari suatu kebaikan yang sudah terbiasa ia lakukan maupun yang belum terbiasa ia lakukan.

3. Feeling and Loving the Good

Dalam hal ini akan terbentuk rasa cinta pada kebaikan, rasa cinta tersebut akan terus tumbuh dan berkembang yang nantinya menjadi suatu dorongan atau power dalam diri sendiri agar selalu berusaha berbuat kebaikan.

4. Acting the Good (tindakan kebaikan) 
Dalam hal ini akan muncul tindakan atau perbuatan yang mencerminkan kebaikan sehingga akan 
mengembangkan karakter-karakter yang baik dalam diri sendiri.

5. Keteladanan

Dalam hal ini, pengalaman-pengalamannya serta sesuatu yang ada di dalam lingkungannya patut untuk diambil hikmahnya dan diteladani karena keteladanan memang sangat diperlukan.

6. Tobat, merupakan kembali kepada Allah SWT setelah melakukan suatu kesalahan namun juga harus bertanggung jawab untuk memperbaiki kesalahan yang pernah dilakukannya.

Prinsip pada pengaplikasian atau penerapan pendidikan nilai karakter tidak dimasukkan sebagai pokok bahasan, melainkan terintegrasi ke dalam semua mata pelajaran, pengembangan diri, dan budaya sekolah. Maka guru dan sekolah harus mengintegrasikan nilai-nilai yang dikembangkan dalam pendidikan karakter ke dalam kurikulum, silabus, dan RPP yang sudah ada.Dapat dikatakan bahwa prinsip yang digunakan dalam pengembangan pendidikan karakter adalah berkelanjutan, melalui semua mata pelajaran, pengembangan diri, dan budaya sekolah. Prinsip selanjutnya nilai tidak diajarkan tetapi dikembangkan. Materi pelajaran yang biasanya digunakan sebagai alat atau media untukmengembangkan nilai- nilai karakter dan nilai-nilai budaya serta proses pendidikan yang dilakukan siswa harus secara aktif dan menyenangkan. Pilar pendidikan karakter secara mikro 
pengembangan nilai atau karakter terdiri dari empat pilar, yakni kegiatan belajar 
mengajar di kelas, kegiatan keseharian dalam bentuk budaya sekolah (school culture), kegiatan ekstrakurikuler, serta kegiatan keseharian di rumah dan di masyarakat.

Dalam kegiatan belajar mengajar di kelas, pengembangan karakter dilakukan dengan menggunakan pendekatan terintegrasi dalam semua mata pelajaran. Dalam lingkungan sekolah, dikondisikan agar lingkungan fisik dan sosial-kultural sekolah mendukung para siswa bersama dengan warga sekolah lainnya terbiasa menciptakan kegiatan yang mencerminkan perwujudan nilai atau karakter. Dalam kegiatan ekstrakurikuler, perlu dikembangkan proses pembiasaan dan penguatan dalam rangka pengembangan karakter. Di lingkungan keluarga dan masyarakat, diusahakan terjadi proses penguatan dari orang tua serta tokoh masyarakat terhadap perilaku berkarakter yang telah dikembangkan di sekolah menjadi kegiatan keseharian di rumah dan di lingkungan masyarakat masing-masing.

Dengan demikian, ada banyak nilai karakter yang dapat dikembangkan dan diintegrasikan dalam pembelajaran di sekolah. Menanamkan semua butir nilai tersebut merupakan tugas yang sangat berat. Oleh karena itu, perlu dipilih nilai-nilai tertentu yang diprioritaskan penanamannya pada peserta didik. 


\section{B. Pendidikan Karakter di Sekolah}

Pendidikan karakter merupakan suatu susunan dalam penanaman nilai-nilai karakter kepada semua warga sekolah termasuk para siswa yang terdiri atas pengetahuan, kesadaran atau kemauan, dan tingkah laku untuk menerapkan nilai-nilai karakter tersebut dalam kehidupan sehari-hari. Dalam pendidikan karakter yang terdapat di sekolah, ada baiknya kalau semua pihak dan unsur dalam pendidikan tersebut dilibatkan. Yaitu isi kurikulum, penanganan atau pengelolaan mata pelajaran, prosespembelajaran dan penilaian, pengelolaan sekolah, pelaksanaan aktivitas ekstrakurikuler, pengelolaan sarana dan prasarana, pendanaan, dan cara kerja seluruh warga sekolah. Dengan demikian, sekolah menjadi tempat yang penting untuk menanamkan nilai-nilai karakter dan sebagai tempat praktek untuk berlatih melakukan nilai-nilai karakter tersebut yang dapat menjadi siswa dalam mengembangkan karakter pribadinya dengan sebaikbaiknya. Sehingga dirasaperlu menganalisis kegiatan atau aktifitas apa saja yang akan menjadi momen yang istimewa bagi siswa di dalam sekolah, dimana hal tersebut dapat dijadikan sebagai ladang pendidikan yaitu :

1. Kegiatan Intrakurikuler

Kegiatan intrakurikuler atau proses belajar mengajar di kelas merupakan kegiatan yang paling utama di dalam sekolah. Dalam kegiatan inisekolah diberi wewenang untuk menerapkan model, 
maupun metode dalam pembelajaran yang efektif sesuai dengan karakteristik mata pelajaran, siswa, dan kondisi yang nyata dalam sekolah. Hal tersebut bertujuan untuk menciptakan lingkungan belajar yang dapat 
membentuk dan mengembangkan pemikiran siswa. Umumnya, proses pembelajaran yang dilakukan yaitu berpusat pada siswa (student center). Artinya proses pembelajaran yang dilakukan menekankan pada keaktifan siswa, bukan pada keaktifan guru. Maka perlu ada penerapan student center dalam pembelajaran seperti active learning, cooperative learning, dan quantum learning. Sehingga segala aktifitas atau kegiatan yang telah direncanakan dan diupayakan guru haruslah mampu memfasilitasi pembentukan dan pengembangan siswa berkarakter dan berakhlak mulia. Salah satu cara yang dapat dilakukan ialah mengintegrasikan nilai-nilai karakter dengan semua mata pelajaran dalam kegiatan pembelajaran. Maksudnya adalah memasukkan, memadukan dan menerapkan nilai nilai karakter ke dalam proses pembelajaran pada setiap materi mata pelajaran untuk membentuk, meluruskan, dan mengembangkan karakter baik pada diri siswa.

2. Kegiatan Ekstrakurikuler

Kegiatan ekstrakurikuler merupakan kegiatan atau aktifitas yang dilakukan siswa di luar jam pelajaran kurikulum standar. Kegiatan seperti ini biasanya terdapat di lembaga pendidikan mulai dari sekolah dasar sampai universitas. Kegiatan ekstrakurikuler diadakan untuk menggali, mengembangkan, dan membina kepribadian, 
bakat, talenta, kemampuan, keahlian dan segala potensi yang ada pada diri siswa di berbagai bidang selain bidang akademik. 
Kegiatan ekstrakurikuler adalah wahana pengembangan pribadi peserta didik melalui berbagai aktifitas, baik yang terkait langsung maupun tidak langsung dengan materi kurikulum, sebagai bagian tak terpisahkan dari tujuan kelembagaan. (yang kami kutip dari buku Manajemen Belajar Berbasis Kepuasan Siswa yang dikarang oleh Dr. Popi Sopiatin, M.Pd halaman 99).

Ada beberapa jenis kegiatan ekstrakurikuler baik yang bersifat langsung maupun tidak langsung berhubungan dengan mata pelajaran. Kegiatan yang secara langsung berhubungan dengan mata pelajaran yaitu olahraga, seni budaya, bimbingan belajar, dan karya ilmiah remaja. Sedangkan kegiatan yang secara tidak langsung berhubungan dengan mata pelajaran yaitu paskibra, PMR, OSIS, dan pramuka. Ada juga kegiatan keagamaan yang menunjukkan adanya fungsi dan pengaruh kegiatan ekstrakurikuler keagamaan terhadap peningkatan iman dan takwa serta etika sosial siswa. Hal tersebut dapat tercapai karena siswa melihat sisi positif fungsi kegiatan ekstrakurikuler keagamaan bagi peningkatan dan pendalaman keagamaan siswa baik dari segi pengetahuan agama, pengembangan pribadi, dan sikap-sikap yang dianjurkan dalam agama. Ada beberapa fungsi kegiatan ekstrakurikuler, diantaranya adalah 
sebagai berikut :

a. Pengembangan, yakni kegiatan ekstrakurikuler untuk mengembangkan kemampuan dan kreatifitas 
siswa sesuai dengan minat, bakat, dan potensi yang ada pada dirinya.

b. Sosial, yaitu fungsi kegiatan ekstrakurikuler untuk mengembangkan kemampuan sosialisasi, komunikasi, adaptasi dan rasa tanggungjawab sosial siswa.

c. Rekreatif, ialah fungsi kegiatan ekstrakurikuler untuk mengembangkan suasana yang menyenangkan, menggembirakan dan mengasyikkan bagi siswa untuk mendukung proses pengembangan.

d. Persiapan karir, kegiatan ekstrakurikuler untuk mengembangkan kesiapan karir siswa.

3. Kurikulum Tersembunyi (Hidden Curriculum)

Kita mengenal beberapa istilah kurikulum, yaitu kurikulum dalam aspek program atau rencana yang biasa disebut kurikulum ideal (ideal curriculum), dan kurikulum dalam aspek pengalaman belajar siswa yang biasa disebut kurikulum aktual (actual curriculum).Kurikulum ideal merupakan kurikulum yang dicita-citakan sesuai dengan apa yang tertuang dalam dokumen kurikulum. Kurikulum ini diharapkan dapat dilaksanakan dan berfungsi sebagai pedoman bagi guru dalam proses pembelajaran. Sedangkan kurikulum aktual merupakan kurikulum yang disajikan oleh guru dalam proses belajar mengajar di kelas. Kurikulum aktual yaitu penjabaran dari kurikulum ideal ke dalam pengembangan 
pembelajaran, dimana kurikulum aktual dilaksanakan secara nyata oleh guru sesuai dengan keadaan yang dihadapi. Termasuk di dalam kurikulum aktual yaitu ada kurikulum tersembunyi (hidden 
curriculum), karena hidden curriculum disajikan dan dialami siswa di dalam maupun di luar kelas.Hidden curriculum adalah kejadian atau kegiatan yang terjadi dan tidak direncanakan sebelumnya, namun dapat dimanfaatkan oleh guru dalam mengembangkan pribadi siswa. Kurikulum tersembunyi pada hakikatnya adalah hasil dari suatu proses pendidikan yang tidak direncanakan, maksudnya perilaku yang muncul di luar tujuan yang telah dirumuskan oleh guru.

Beberapa konsep tentang hidden curriculum menyimpulkan bahwa hidden curriculum adalah tingkah laku, sikap, gaya bicara, dan perlakuan para guru terhadap muridnya yang mengandung pesan moral. (yang kami kutip dari dalam jurnal penelitian Membangun Karakter Siswa Melalui Kegiatan Intrakurikuler, Ekstrakurikuler, dan Hidden Curriculum oleh Prawidya Lestari dan Sukanti STAINU Purworejo, Jawa Tengah)

Inti dari hidden curriculum adalah kebiasaan- kebiasaan sekolah dalam menerapkan disiplin kepada siswanya. Seperti ketepatan guru dalam memulai pelajaran atau tidak terlambat, cara guru dalam mengkondisikan kelas, dan perlakuan guru terhadap siswa yang melakukan kebaikan 
ataupun kesalahan di dalam dan di luar kelas. Dalam penerapannya kurikulum di kelas, kurikulum tersembunyi (hidden curriculum) memiliki dua makna. Yaitu yang pertama, 
kurikulum tersembunyi dapat dipandang sebagai tujuan yang tidak tertulis (tersembunyi), namun pencapaiannya harus dipertimbangkan oleh setiap guru agar kualitas atau mutu pembelajaran lebih bermakna bagi siswa. Dan yang kedua, kurikulum tersembunyi juga dapat diartikan sebagai seluruh kejadian yang terjadi tanpa adanya perencanaan terlebih dahulu yang dapat dimanfaatkan oleh guru dalam membantu siswa mencapai tujuan pembelajaran. 


\section{Peran Strategis Kegiatan Ekstrakulikuler Sebagai Pembentuk Karakter}

Kegiatan ekstrakulikuler merupakan kegiatan di luar mata pelajaran yang ada di sekolah yang berguna bagi peserta didik sebagai tempat pengembangan potensi dan bakat yang ada di diri peserta didik itu yang dilaksanakan oleh pendidik yang memiliki kemampuan tertentu dan kewenangan dari sekolah.

Kegiatan ekstrakulikuler adalah kegiatan pendidikan di luar mata pelajaran dan pelayanan konseling untuk membantu pengembangan peserta didik sesuai dengan kebutuhan, potensi, bakat, dan minat mereka melalui kegiatan yang secara khusus diselenggarakan oleh pendidik dan atau tenaga kependidikan yang berkemampuan dan berkewanangan di sekolah/madrasah. (yang kami kutip dari buku The Hidden Curriculum yang dikarang oleh Rohinah M. Noor, MA halaman 75).

Dilihat pendidikan saat ini praktiknya menunjukkan bahwa pendidikan lebih fokus kepada agar siswa menguasai informasi yang terkandung di dalam mata pelajaran, lalu kemudian di evaluasi dari berapa jauh penguasaan pemahaman yang dicapai oleh peserta didik. Pendidikan seperti terlepas dari kehidupan nyata 
sehari-hari dan bagaimana materi tersebut dapat digunakan dalam pemecahan masalah di kehidupan sehari-hari. Sehingga para peserta didik tidak mengetahui fungsi guna dalam mempelajari materi tersebut, sehingga materi yang di di dapat 
seakan sia-sia untuk dipelajari. Karena hal tersebut, maka perlu adanya sebuah pembelajaran yang ada di akdemik yang memberikan bekal kepada peserta didik untuk memecahkan masalah kehidupan sehari-hari, tidak hanya belajar tentang teori-teori yang ada di buku tetapi juga mempraktekannya dalam kehidupan sehari- hari.

Perlu diterapkan prinsip pendidikan berbasis luas yang tidak hanya berorientasi pada bidang akademik, tetapi juga memberikan bekal learning how to learn sekaligus learning how to unlearn, tidak hanya belajr teori, tetapi juga mempraktikannya dalam kehidupan sehari-hari. (yang kami kutip dari buku The Hidden Curriculum yang dikarang oleh Rohinah M. Noo, MA halaman 96).

Banyak yang dapat diberikan oleh kegiatan ekstrakulikuler untuk meningkatkan kualitas peserta didik, diantara lain:

1. Mengondisikan keberagaman kecerdasan dan potensi siswa

Kecerdasan manusia bukan hanya kecerdasan intelektual (IQ) saja, tetapi juga kecerdasan emosional (EQ) dan kecerdasan religius (SQ), sehingga perlu adanya layanan bimbingan yang beragam. Jadi, dalam kegiatan ekstrakulikuler 
diharapkan dapat

mengembangkan

kecerdasan-kecerdasan tersebut secara

seimbang. 
2. Lebih mendekatkan pendidikan

pada dunia riil Kegiatan

ekstrakulikuler akan mengajak

peserta didik untuk merasakan dunia riil dimana mereka bisa berosialisasi dengan masyarakat sehingga mereka bisa menerapkan ilmu yang di dapat kepada masyarakat.

3. Memilih fleksibilitas yang tinggi dari segi program dan kurikulum

Kurikulum memiliki batasan karena kurikulum pendidikan formal hanya mempunyai kemampuan untuk menerapkan ilmu di masyrakat. Sehingga perlu adanya kegiatan yang memiliki peranan untuk mengubah manusia menjadi produkti dan kreatif, salah satunya dengan cara kegiatan ekstrakulikuler.

4. Pendidikan disampaikan secara menarik dan menyenangkan

Kegiatan ekstrakulikuler hanya diikuti oleh beberapa siswa yang memang minat dengan kegiatan tersebut, sehingga mereka akan lebih termotivasi dalam kegiatan itu. Kegiatan ekstrakulikuler biasanya juga dilaksanakan di luar ruangan sehingga terasa menyenangkan, dan dalam kegiatan ekstrakulikuler tidak menekankan siswa pada pemahaman pada sebuah materi tertentu. 


\section{Contoh Program Sekolah (SDN Rejasa}

\section{Banjarnegara, Jawa Tengah)}

SDN Rejasa memiliki sasaran dalam pelaksanaan program sekolah. Sasaran merupakan kegiatan yang spesifik yang dilakukan untuk mencapai hasil dari suatu program. Berikut ini diuraikan beberapa sasaran dari program sekolah di SDN Rejasa dalam jangka menengah.

1. Bidang kesiswaan

Di dalam bidang kesiswaan meliputi kegiatan:

a. Adanya penambahan siswa, rata-rata setiap tahunnya minimal 5 orang siswa

b. Dalam waktu 4 tahun ke depan terbantunya siswa yang kurang mampu secara ekonomi rata- rata 10 orang pertahunnya

c. Adanya kesadaran orang tua siswa dan masyarakat peduli pendidikan yang secara bersama-sama memperhatikan pendidikan anaknya jangan sampai putus sekolah

d. Meningkatnya kehadiran siswa rata-rata $85 \%$ menjadi minimal $97 \%$

e. Terperhatikannya siswa yang mempunyai kecerdasan tinggi maupun rendah

f. Terbinanya siswa yang mengulang kelas dari kelas I s.d VI

g. Adanya perhatian khusus bila terdapat siswa yang putus sekolah

Dari beberapa kegiatan di atas dapat dianalisis bahwa program dalam bidang kesiswaan 
menargetkan untuk menambah siswa yang ada di sekolah setiap tahunnya, selain itu dengan adanya penambahan siswa 
tersebut sekolah juga harus mengimbangi dengan perhatian khusus terhadap siswa yang putus sekolah.

2. Kurikulum dan Kegiatan Pembelajaran

Program kurikulum dan kegiatan pembelajaran SDN Rejasa adalah:

a. Guru SDN Rejasa mampu dalam membuat dan merencanakan sistem pembelajaran sesuai dengan tuntutan KTSP

b. Guru lebih terarah dan mudah melaksanakan pembelajaran bila mempunyai silabus dan rencana pembelajaran

c. Sesuainya isi silabus dengan rencana pembelajaran dan kegiatan belajar mengajar

d. Pembelajaran akan lebih baik dan berhasil bila mempergunakan sistem pembelajaran aktif, kreatif, efektif, dan menyenangkan (Pakem)

e. Semua guru mampu menggunakan media atau alat peraga dalam pembelajaran di kelas

f. Diraihnya prestasi akademik dalam lomba mata pelajaran matematika dan IPA (Lomba MIPA) serta mata pelajaran lainnya

g. Tercapainya nilai maksimal untuk mata pelajaran PKn, Bahasa Indonesia, Matematika, IPA, dan IPS dari kelas I s.d VI

h. Tercapainya kelulusan $100 \%$ bagi siswa kelas VI pada setiap tahunnya 
i. Semua siswa yang lulus dapat melanjutkan ke jenjang yang lebih tinggi (SLTP) atau yang sederajat. 
j. Semua siswa yang berbakat olahraga dan seni dapat meraih prestasi minimal masukdalam peringkat 3 besar tingkat kecamatan atau kabupaten

k. Terbinanya siswa yang berbakat olahraga dan seni.

Dari beberapa kegiatan di atas dapat dianalisis bahwa program dalam bidang kurikulum dan kegiatan pembelajaran mengedepankan siswa untuk berprestasi. Tidak hanya berprestasi dalam bidang akademik, tetapi juga bidang olahraga dan seni.

3. Pendidik dan Tenaga Kependidikan

Beberapa progam untuk pendidik dan tenaga kependidikan antara lain:

a. 3 guru yang sebelumnya non PNS mempunyai penghasilan tetap

b. 5 guru yang berijazah DII dapat menyelesaikan pendidikan dan memiliki ijazah SI

c. Terpenuhi kebutuhan olahraga dan penjaga sekolah guna efektifitas pelaksanaan pendidikan di sekolah

d. Kepala sekolah memiliki wawasan yang luas, kreatif, inovatif, trampil memonitoring, mampu mengevaluasi, dan menindaklanjuti hasil akreditasi.

Dari beberapa kegiatan di atas dapat 
dianalisis bahwa program dalam bidang pendidik dan tenaga kependidikan, untuk menunjang kegiatan pembelajaran 
maka perlu adanya tenaga pendidik yang profesional, sehingga para pendidik tersebut tidak hanya mengedepankan nilai akademiknya saja, tetapi juga menumbuhkan karakter pada diri siswa.

\section{Manajemen}

Terjadinya harmonisasi hubungan antara pihak sekolah dengan masyarakat dan unsur dinas pendidikan untuk memajukan dunia pendidikan.Beberapa kegiatan dalam bidang manajemen, antara lain:

a. Manajemen Pembelajaran. Tersedianya sistem yang lebih sempurna, terlibatnya secara aktif peran komite sekolah dan guru dalam pengelolaan pembelajaran.

b. Manajemen Peserta Didik. Tersedianya sistem yang lebih sempurna dan peran aktifnya komite sekolah dalam pengelolaan manajemen peserta didik. Misalnya pengawasan bersama dalam jam wajib belajar di rumah.

c. Manajemen Personalia. Tersedianya sistem yang lebih sempurna dan berperan aktifnya kepala sekolah, guru, dan komite dalam pengelolaan manajemen personalia. Menyediakan reward/ hadiah bagi guru yang memiliki kinerja yang baik.

d. Manajemen Sarana dan Prasarana. Berperan aktifnya semua unsur, seperti kepala sekolah, guru, dan komite dalam pengelolaan sarana 
dan prasarana. Penertiban administrasi sarpras yang baik.

e. Manajemen Keuangan dan Pembiayaan. Terciptanya transparansi manajemen bagi semua 
unsur dalam pengadaan dan pengelolaan keuangan dengan adanya keterlibatan komite, guru, dan masyarakat.

Dari beberapa kegiatan di atas dapat dianalisis bahwa program dalam bidang manajemen dapat dikatakan baik, karena keadaan manajemen telah diatur secara tertulis dan tinggal melaksanakannya, bahkan ada pemberian reward bagi guru yang memiliki kinerja baik, sehingga hal tersebut dapat meningkatkan kinerja guru untuk membuat peserta didik menjadi siswa yang pandai dan berkarakter.

\section{Sarana dan Prasarana}

Beberapa kegiatan dalam program sarana dan prasarana antara lain:

a. Terpenuhinya sarana pendukung kegiatan pendidikan di sekolah yang lengkap dan kondisi baik, seperti mushola, halaman sekolah, tempat parkir, termasuk gerbang sekolah untuk keamanan lingkungan sekolah

b. Terpenuhinya kebutuhan 6 ruang kelas yang memadai dan layak pakai untuk kegiatan pembelajaran

c. Memiliki ruang perpustakaan yang memenuhi standar

d. Tercukupinya buku paket murid untuk semua mata pelajaran.

e. Tersedianya buku pegangan guru dari beberapa penerbit 
f. Lengkapnya alat pembelajaran seperti KIT IPA, KIT Matematika, KIT IPS, Bahasa Indonesia, alat olahraga, dan kesenian

g. Memiliki jaringan telepon dan internet untuk meningkatkan layanan sistem informasi

h. Dimilikinya prasarana air bersih untuk keperluan kebersihan dan kesehatan sekolah.

Dari beberapa kegiatan di atas dapat dianalisis bahwa program dalam bidang sarana dan prasarana telah tertulis bahwa SDN Rejasa meningkatkan fasilitas sekolah demi kenyamanan kegiatan-kegiatan yang ada di sekolah agar berjalan dengan baik. Hal tersebut membuat para peserta didik bisa bersemangat untuk belajar jika sarana dan prasarana dilengkapi dengan baik.

6. Perlengkapan IT

Beberapa kegiatan dari program perlengkapan IT, antara lain:

a. Terpenuhinya peralatan komputer/ desktop beserta printernya sebagai sarana administrasi perkantoran atau tata usaha sekolah.

b. Memiliki LCD proyektor sebagai media pembelajaran di kelas.

c. Memiliki laboratorium Komputer.

Dari beberapa kegiatan di atas dapat dianalisis 
bahwa program dalam bidang perlengkapan IT dapat dikatakan lengkap, karena dalam tingkatan SD memang mungkin sekedar mengenal tentang IT, sehingga 
perlengkapan yang ada dikatakan lengkap agar tidak tertinggal oleh sekolah yang lain.

7. Keuangan dan Pembiayaan

Kegiatan dalam program keuangan dan pembiayaan adalah selain bersumber dari BOS untuk mencukupi dana operasional, utamanya dalam hal pembinaan prestasi siswa akan dilakukan penggalian dana secara kreatif seperti membuka kantin sekolah, koperasi sekolah atau kerja sama dengan dunia usaha dan mencari donatur sekolah.Dari kegiatan di atas dapat dianalisis bahwa program dalam bidang keuangan dan pembiayaan, sekolah sangat menekankan agar dapat memfasilitasi sekolah dengan baik. Karena memang dana BOS dirasa masih kurang untuk memenuhi fasilitas sekolah, maka perlu adanya dana tambahan dengan cara mencari donatur.

8. Budaya dan Lingkungan Sekolah

Berikut beberapa kegiatan dalam program budaya dan lingkungan sekolah, antara lain:

a. Terbiasanya hidup rukun, damai, dan harmonis di sekolah dan di tengah-tengah masyarakat.

b. Terwujudnya lingkungan yang bersih, nyaman dan aman di sekolah.

c. Terciptanya situasi yang religius dan terbiasa 
beribadah di sekolah.

Dari beberapa kegiatan di atas dapat dianalisis bahwa program dalam bidang budaya dan lingkungan 
sekolah ini, sekolah tidak hanya menekankan nilai akademik, tetapi juga penanaman karakter baik. Penanaman karakter ini dilakukan oleh semua warga sekolah, agar peseerta didik menjadi terbiasa dengan lingkungan yang baik.

9. Peran Serta Masyarakat

Beberapa kegiatan dalam program peran serta masyarakat, antara lain:

a. Tersedianya AD/ART komite, program kerja, dan laporan pertanggung jawaban kegiatan

b. Komposisi anggota komite yang berasal dari berbagai unsur

c. Terprogramnya jadwal pertemuan rutin komite dengan sekolah dan antar komite

d. Peningkatan dukungan dan peran serta masyarakat terhadap sekolah.

Dari beberapa kegiatan di atas dapat dianalisis bahwa program dalam bidang peran serta masyarakat adalah tidak hanya sekolah yang berusaha meningkatkan kegiatan sekolah tetapi peran serta masyarakat juga ikut membangun sekolah demi mewujudkan karakter baik anak. 


\section{KESIMPULAN}

Pendidikan karakter bukan hanya sekedar mengajarkan mana yang benar dan mana yang salah. Pendidikan karakter mengupayakan untuk menanamkan kebiasaan-kebiasaan baik pad asiswa, sehingga perilaku- perilaku tersebut telah menjadi bagian dari kepribadiannya. Pendidikan karakter yang baik melibatkan pengetahuan yang baik (moral knowing), perasaan yang baik (moral feeling), dan berperilaku yang baik (moral action). Pendidikan karakter di sekolah dapat dilakukan melalui beberapa kegiatan, yang pertama kegiatan intrakulikuler dengan cara memasukkan, memadukan, dan menerapkan nilai-nilai karakter ke dalam proses pembelajaran pada setiap materi mata pelajaran untuk membentuk, meluruskan, dan mengembangkan karakter baik pada diri siswa. Yang kedua, kegiatan ekstrakulikuler yang diadakan untuk menggali, mengembangkan, dan membina kepribadian, bakat, talenta, kemampuan, keahlian, dan segala potensi yang ada pada diri siswa di berbagai bidang. Dan yang ketiga yaitu kurikulum tersembunyi (hidden curriculum) yang menerapkan disiplin kepada siswanya melalui kebiasaan-kebiasaan sekolah.

Salah satu pengembangan pendidikan karakter yaitu melalui kegiatan ekstrakulikuler dimana kegiatan tersebut untuk meningkatkan kualitas peserta didik dengan cara seperti mengondisikan keberagaman kecerdasan dan potensi siswa, lebih mendekatkan pendidikan pada dunia riil, dan menyampaikan 
pendidikan secara menarik serta menyenangkan, kegiatan ekstrakulikuler memiliki fleksibilitas yang tinggi dari segi program dan kurikulum. Ada 
contoh program sekolah di SDN Rejasa Banjarnegara, Jawa Tengah dengan memiliki program sekolah melalui bidang kesiswaan, bidang kurikulum dan kegiatan pembelajaran, bidang pendidik dan tenaga kependidikan, bidang manajemen, bidang sarana dan prasarana, bidang perlengkapan IT, serta biang keuangan dan pembiayaan. 


\section{BAB 7}

Perancangan Sebuah Pembelajaran Berbasis Outdoor Learning Pkn Sd Kelas Awal Yang Inovatif Dan Berkarakter

CP-MK Capaian Pembelajaran Mata Kuliah :

A. Mahasiswa dapat memahami Hakekat Outdoor Learning

B. Mahasiswa dapat mendeskripsikan Hakekat Nilai Karakter

C. Mahasiswa dapat menganalisis Pencapaian Nilai Karakter Pada Outdoor Learning

D. Mahasiswa dapat mendeskripsikan Langkah Langkah Metode Outdoor Learning

E. Mahasiswa dapat mendeskripsikan Manfaat Outdoor Learning

A. Hakekat Outdoor Learning

Menurut Neil, beberapa peneliti mengambil falsafah Outdoor learning dari Outdoor Educationberdasarkan teori dari Comenius, Rousseau,dan Pestalozzi, yang hakikatnya adalah sebagaiberikut:

Dalam buku James Neil: 2006, John Amos Comenius (1592-1670), menyatakan dia berpikir bahwa penggunaan indera penglihatan, pendengaran, pengecapan, dan sentuhan merupakan jalan dimana anak-anak datang untuk berhubungan dengan alam. Dalam persiapan untuk studi selanjutnya tentang ilmu pengetahuan alam, anak-anak 
terlebih dahulu harus berkenalan dengan objek seperti air, tanah, api, hujan, tanaman, dan bebatuan. 
Dari teori John Amos Comenius ini dapat disimpulkan bahwa peserta didik harus mampu mempelajari hal-hal yang sudah di pelajari sebelumnya yaitu mempelajari tentang pengetahuan indrawi. Indrawi disini peserta didik berfikir dengan menggunakan indra penglihatan, pendengaran, pengecapan dan sentuhan yang merupakan tempat dimana peserta didik berinteraksi langsung dengan alam di sekitarnya. Untuk mempersiapkan materi selanjutnya yang mengenai ilmu pengetahuan alam peserta didik akan dikenalkan terlebih dahulu dengan benda-benda yang ada di alam sekitar misalnya air, tanah, api, hujan, tumbuhan, bebatuan dan sebagainya.

Dalam buku James Neil: 2004, Jean-Jacques Rousseau (1712-1778) menjalankan gagasan Comenius dengan mendidik anak laki-laki itu, Emile, sesuai prinsip yang ditemukan di alam. la percaya bahwa aktivitas fisik sangat penting dalam pendidikan anak. Mereka penasaran, katanya dan keingintahuan ini harus di suntik sepenuhnya. Rousseau berkhotbah bahwa pendidikan harus lebih sensoris dan rasional; kurang literer dan linguistik. Alih-alih belajar secara tidak langsung dari buku, anak harus belajar melalui pengalaman langsung.

Dari teori yang dikemukakan Jean Jacques Rousseau ia berpendapat tidak jauh berbeda dengan pendapat yang dikemukakan oleh John Amos 
Comenius yaitu ia yakin bahwa interaksi fisik sangat berperan penting dalam pendidikan peserta didik terutama aktivitas di luar 
kelas. Interaksi fisik diluar kelas diharapkan akan menimbulkan sikap ilmiah pada diri peserta didik. Sikap ilmiah tersebut akan mendorong peserta didik untuk mengemukakan rasa ingin tahunya melalui pertanyaan- pertanyaan saat pembelajaran berlangsung. Dari teori Jean Jacques Rousseau dapat digaris bawahi bahwa ia menganggap pembelajaran tidak hanya terpaku dengan buku, namun peserta didik seharusnya dapat belajar secara langsung dan menemukan konsep sendiri.

Dalam buku James Neil: 2004, Johann Henrick Pestalozzi (1746-1827) menekankan penggunaan langsung, pengalaman langsung dan benda nyata juga. Disana dia akan mendengarkan dengan lebih baik, dan rasa kebebasan akan memberinya lebih banyak kekuatan untuk mengatasi kesulitan. Tapi dimasa kebebasan ini diarkan dia diajar secara alami dan bukan oleh Anda. Biarkan dia menyadari sepenuhnya bahwa dia adalah guru sejati dan bahwa Anda dengan seni Anda tidak melakukan apa-apa selain berjalan diam dipihaknya.

Tidak jauh berbeda dengan teori yang dikemukakan Johann Henrick Pestalozzi, ia juga menganggap bahwa peserta didik butuh pengalaman langsung dari benda-benda yang ada di sekitar. Johann Henrick Pestalozzi berpendapat sama dengan Jean Jacques Rousseau yaitu menuntut para guru 
untuk melakukan pembelajaran di luar kelas. Mengajak peserta didik langsung terjun ke alam, hal ini bertujuan agar peserta didik dapat merasakan ketenangan saat pembelajaran berlangsung. Namun saat pembelajaran diluar kelas ini 
berlangsung seharusnya guru membiarkan peserta didik untuk belajar dari alam.

Metode pembelajaran Outdoor Learning memberikan alternatif cara pembelajaran dengan membangun makna atau dengan melibatkan lebih banyak indera penglihatan, indera pendengaran, indera perabaan, dan indera penciuman pada siswa agar siswa lebih termotivasi belajar dengan memanfaatkan lingkungan sebagai sumber belajarnya. Kegiatan pembelajaran yang monoton dan membosakan terkadang cepat membuat siswa merasa bosan di dalam kelas, misalnya dalam pelajaran PKN yang hanya dilakukan dalam kelas, mengharuskan siswanya untuk duduk rapi, mendengarkan penjelasan materi dari guru dan hanya menjadikan buku dan ruang kelas sebagai satu-satunya sumber belajar bagi siswa. Padahal di luar kelas sana dapat dijadikan tempat belajar yang lebih menyenangkan dan lebih memberi keluasan bagi siswa dalam memperoleh pengalaman dalam pembelajaran dibandingkan hanya duduk di ruang kelas.

\section{B. Hakekat Nilai Karakter}

Pendidikan karakter merupakan suatu tindakan yang bertujuan untuk menanamkan nilai-nilai karakter kepada seseorang. Sikap dan perilaku peserta didik akan tumbuh ketika kegiatan belajar mengajar itu berlangsung. Dalam menumbuhkan karakter ini peserta didik sangat membutuhkan bantuan dan pembinaan dari beberapa pihak untuk dapat 
menunjukkan sikap dan perilaku yang baik sesuai dengan nilai-nilai agama, pancasila, budaya, dan lain-lain. Dari beberapa nilai pembentuk karakter ini 
akan tertanam ke dalam diri peserta didik sesuai sikap dan perilaku yang ditumbuhkan.

Nilai-nilai pembentuk karakter yang bersumber dari agama, pancasila, budaya dan tujuan pendidikan nasional, (Pusat Kurikulum, Pengembangan dan Pendidikan Budaya \& Karakter Bangsa: Pedoman Sekolah, antara lain :

1. Religius: Sikap dan perilaku yang patuh dalam melaksanakan ajaran agama yang dianutnya, toleran terhadap pelaksanaan ibadah agama lain, dan hidup rukun dengan pemeluk agama lain.

2. Jujur: suatu tindakan yang dilakukan sebagai usaha menjadikan dirinya sebagai pribadi yang dapat dipercaya dalam ucapan, perbuatan dan pekerjaan.

3. Toleransi: Sikap dan tindakan yang menghargai perbedaan agama, suku, etnis, pendapat sikap dan tindakan orang lain yang berbeda dari dirinya.

4. Disiplin: Suatu tindakan yang mencerminkan sikap tertib dan patuh pada berbagai tata tertib atau peraturan.

5. Kerja Keras: Suatu upaya seseorang untuk bersungguh-sungguh dalam menjalani berbagai tugas dan akan menjalani tugas tersebut dengan sebaik-baiknya.

6. Kreatif: Sebuah pola pikir untuk menciptakan hal-hal baru yang lebih indah 
daripada hal-hal sebelumnya.

7. Mandiri: Sikap seseorang untuk berdiri dikakinya sendiri yang artinya seseorang tersebut 
akan belajar sebaik mungkin untuk tidak bergantung kepada orang lain.

8. Demokratis: Sebuah sikap dimana seseorang dapat membedakan hak atau kewajiban sehingga orang tersebut akan bersikap dan bertindak sesuai hak dan kewajiban dirinya dan orang lain.

9. Rasa Ingin Tahu: Sikap dan tindakan yang selalu berusaha untuk mencari tahu beberapa fakta yang baru atau yang belum diketahuinya.

10. Semangat Kebangsaan: merupakan pola pikir, tindakan dan sikap yang mengutamakan kepentingan bangsa dan negara di atas kepentingan pribadi dan kelompoknya.

11. Cinta Tanah Air: Sebuah pola pikir, tindakan dan sikap yang mengutamakan kepentingan bangsa dan negaranya daripada kepentingan diri dan kelompoknya.

12. Menghargai prestasi: Suatu tindakan, perilaku maupun sikap seseorang yang mendorong dirinya untuk dapat menghargai dan menghormati suatu keberhasilan yang dimiliki oleh orang lain.

13. Bersahabat atau komunikatif: Suatu sikap dan tindakan seseorang yang mendorong dirinya untuk dapat menempatkan diri di lingkungan masyarakat dan berinteraksi baik dengan orang lain. 
14. Cinta damai: Suatu sikap dan tindakan yang mendorong seseorang untuk mencintai keberagaman sesuai dengan apa yang ada di masyarakat. 
15. Gemar membaca: Keterampilan meluangkan waktu guna membaca beberapa bacaan yang memberikan informasi terhadap pembacanya.

16. Peduli lingkungan: Suatu perilaku atau sikap yang berusaha untuk mencegah kerusakan pada lingkungan sekitarnya dan berusaha untuk menemukan serta mengembangkan cara-cara guna memperbaiki kerusakan alam yang telah terjadi sebelumnya. 17. Peduli sosial: Suatu tindakan atau sikap yang selalu ingin mendedikasikan dirinya untuk membantu orang lain dan masyarakat yang membutuhkan bantuan.

18. Tanggung jawab: Suatu tindakan atau perilaku seseorang untuk memenuhi tugas dan kewajibannya yang memang seharusnya dia laksanakan terhadap dirinya sendiri, lingkungan masyarakat, lingkungan sosial, negara dan Tuhan Yang Maha Esa.

Menurut Samani dan Hariyanto 18 nilai karakter bangsa yang bersumber dari agama, pancasila, budaya dan tujuan pendidikan nasional dapat dikelompokkan menjadi 5 butir nilai utama, yaitu :

1. Nilai karakter dalam hubungannya dengan Tuhan yaitu religius.

2. Nilai karakter hubungannya dengan diri 
sendiri yaitu jujur, bertanggung jawab terhadap diri sendiri, masyarakat dan lingkungannya, bergaya hidup sehat, disiplin, kerja keras, percaya diri, 
berjiwa wirausaha, berpikir logis, kritis, kreatif dan inovatif, mandiri, ingin tahu, cinta ilmu.

3. Nilai karakter hubungannya dengan sesama yaitu seseorang yang mengerti atas dan kewajiban orang lain, taat terhadap tata tertib dimanapun dia berada, menghormati dan menghargai karya maupun prestasi orang lain, sopan santun dan memiliki sikap demokratis.

4. Nilai karakter hubungannya dengan lingkungan yaitu seseorang yang peduli terhadap sosial dan lingkungan sekitarnya.

5. Nilai kebangsaan yaitu dimana seseorang memiliki jiwa patriotism dan nasionalis dalam menghargai berbagai keberagaman didalam lingkungannya.

Untuk memunculkan nilai-nilai karakter di atas, tentunya membutuhkan bantuan dari beberapa pihak seperti guru, teman, dan dari pihak yang lain untuk memunculkan nilai karakter dalam diri peserta didik tersebut. Pembelajaran PKn ini memang berfungsi sebagai pembentuk karakter dan jiwa patriotisme. Maka nilai-nilai karakter harus ditumbuhkan selama proses pembelajaran berlangsung maupun sesudahnya. Penanaman nilai karakter merupakan proses kegiatan belajar mengajar yang secara menyeluruhdialami oleh peserta didik dalam mempelajari pengetahuan yang sudah dipelajari sebelumnya sebagai pengalamanpembentukan kepribadian dengan cara memahamidan mengalami 
sendiri nilai-nilai tersebut. 


\section{Pencapaian Nilai Karakter Pada Outdoor Learning}

Nilai karakter adalah nilai dari sebuah keterampilan seseorang dalam ranah pandangan yang positif, dan memiliki manfaat untuk pengembangan dirinya sendiri. Dalam proses nilai karakter akan terjadi proses penanaman nilai-nilai prilaku (karakter) guna agar setiap individu memahami, perduli, berprilaku, sesuai dengan norma atau nilai etika dasar.

Althof dan Berkowits mengidentifikasi perbedaan pendidikan moral dan pendidikan karakter. Pendidikan moral fokus pengajarannya pada pengembangan penalaran rasa keadilan dan moralitas terhadap kepedulian antar individu. Sedangkan pendidikan karakter fokus pengajarannya pada pengembangan karakter dari dalam (rohani) dan pengembangan karakter dari luar (jasmani) individu.

Pada dasarnya pendidikan karakter dapat disebut dengan "the deliberate use of all dimensions of school life to foster optimal character development". Dalam pendidikan karakter di sekolah, guru harus mempunyai bekal dalam pengajarannya yaitu komponen-komponen pembelajaran yang sangat penting untuk mencapai keberhasilan dalam sebuah pembelajaran. Dan komponen- komponen pembelajaran tersebut antara lain silabus, rencana 
proses pembelajaran, bahan ajar siswa, lembar kerja siswa, media, dan lembar penilaian ini harus sesuai dengan kurikulum yang digunakan. 
Menurut Zamroni dalam Zuchdi pendidikan karakter merupakan proses untuk mengembangkan pada diri setiap peserta didik kesadaran sebagai warga bangsa yang bermartabat, merdeka, dan berdaulat serta berkemauan untuk menjaga dan mempertahankan kemerdekaan dan kedaulatan tersebut.

Ada beberapa macam kriteria dalam pembentukan karakter untuk mewujudkan generasi yang unggul. Nilai - nilai karakter yang pantas mrnurut sudut pandang agama, pancasila, budaya serta dapat mencapai tujuan utama pendidikan nasional.

Pendidikan lingkungan hidup sangat perlu untuk diupayakan sejak dini terhadap siswa. Sebab pada hakikatnya seorang individu akan selalu berinteraksi dan belajar dari lingkungan hidup. Ketika seorang siswa berhasil untuk memahami keterikatan lingkungan alam dengan kehidupan manusia , maka sesungguhnya di saat itulah manusia akan bisa menghargai dan turut serta dalam upaya pelestarian lingkungan alam guna masa depan, dinyatakan oleh (Azwar Faizah: 2015).

Perilaku peduli lingkungan adalah keahlian untuk menentukan pilihan tentang bagaimana cara bersikap merespon berdasarkan kelestarian 
lingkungan. Impuls dorongan hati. Perilaku peduli lingkungan berlandaskan pada sikap beretika terhadap lingkungan, dan sikap beretika terhadap lingkungan yang diterapkan dalam 
pembelajaran PKN antara lain: (1) sikap menjaga lingkungan, (2) sikap bertanggung jawab terhadap lingkungan, (3) sikap menjaga keutuhan bersama, (4) sikap kasih sayang, (5) sikap tidak merusak lingkungan, (6) sikap hidup sederhana dan sejalan dengan alam, (7) sikap keadilan, (8) sikap demokrasi, dan (9) sikap integritas moral. Metode Outdoor Learning salah satunya sebagai metode yang mampu memanfaatkan lingkungan sekitar kepada peserta didik baik sebagai media maupun sumber belajar pembelajaran PKN, dengan Outdoor Learning lah peserta didik akan memahami makna lingkungan sebagai sumber belajar PKN sekaligus sebagai jalan memperkenalkan peran penting dari lingkungan, menjadi jalan untuk meningkatkan kapasitas belajar peserta didik dan menjadikan peserta didik lebih memahami objek-objek yang dihadapi dari pada jika belajar di dalam kelas yang memiliki banyak keterbatasan. Dengan belajar di luar kelas ini dapat mendorong peserta didik untuk memunculkan rasa ingin tahu mengenai pengetahuan yang sudah diperoleh sebelumnya. Selain itu, pembelajaran di luar kelas dapat membuat peserta didik lebih tertantang karena antara teori di dalam buku dan kenyataan yang ada di lapangan sangat berbeda.

\section{Langkah - Langkah Metode Outdoor Learning}

Kegiatan belajar mengajar di luar kelas (outdoor learning) tidak boleh dilakukan secara sembarangan. Pengajaran harus tetap memiliki 
konsep dan langkah- langkah kegiatan yang jelas, sehingga bisa menjadi acuan utama bagi seorang guru yang mengajar siswa di luar kelas. Kegiatan metode ini bukan sekedar main-main untuk 
menyegarkan pikiran dan mengobati kejenuhan, melainkan guna mencerdaskan para siswa dan membuat mereka memahami mata pelajaran dengan baik.

Menurut Widayanti, adapun langkah-langkah pembelajaran outdoor learning atau pembelajaran luar kelas antara lain adalah sebagai berikut :

a. Guru mengajak siswa ke lokasi di luar kelas

b. Guru mengelompokkan siswa

c. Guru mengucapkan salam

d. Guru memberi motivasi

e. Guru memberikan paduan belajar kepada masing- masing kelompok

f. Guru memberikan penjelasan cara kerja kelompok

g. Masing-masing kelompok berpencar pada lokasi untuk melakukan pengamatan dan di beri waktu

h. Guru membimbing siswa selama pengamatan di lapangan

i. Selesai pengamatan siswa di suruh berkumpul kembali untuk mendiskusikan hasil pengamatannya

j. Guru memandu diskusi dan siswa diberi kesempatan mempresentasikan hasil diskusinya masing-masing kelompok dan kelompok lain diberi waktu untuk menanggapi.

Dari langkah-langkah di atas terlihat jelas bahwa pembelajaran di luar kelas dapat membuat 
siswa lebih dapat mengenal alam sekitar sebagai media untuk belajar siswa. Proses belajar dalam metode outdoor learning secara garis besar dapat disimpulkan bahwa metode yang membawa siswa ke luar kelas/ ruangan untuk belajar lebih 
lanjut dengan menggunakan media alam sebagai sumber belajar.

\section{E. Manfaat Outdoor Learning}

Metode pembelajaran outdoor learning memberikan alternatif cara pembelajaran dengan membangun makna atau dengan melibatkan lebih banyak indera penglihatan, indera pendengaran, indera perabaan, indera penciuman pada siswa dan memberikan pengalaman lebih berkesan, karena siswa mengalami sendiri tentang materi pelajaran. Selain itu, kegiatan belajar mengajar di luar kelas (outdoor learning) sangat berpengaruh terhadap kesuksesan belajar dan kecerdasan para siswa. Kegiatan belajar mengajar di luar kelas bukan hanya sekedar untuk menghilangkan rasa bosan karena terlalu lama berada di ruang kelas, melainkan jauh lebih penting dari itu, yaitu untuk menyeimbangkan antara pengetahuan kognitif mereka dengan pengetahuan motorik mereka.

Menurut Sudjana dan Rival, beberapa kelemahan dan kekurangan yang sering terjadi dalam pelaksanaan kegiatan pembelajaran outdoor learning berkisar pada teknis pengaturan waktu dan kegiatan pembelajaran antara lain:

a. Kegiatan belajar kurang dipersiapkan sebelumnya yang menyebutkan ada waktu siswa dibawa ke tujuan tidak melakukan kegiatan belajar yang diharapkan sehingga 
ada kesan main-main.

b. Ada kesan guru dan siswa bahwa kegiatan mempelajari lingkungan memerlukan waktu yang 
cukup lama sehingga menghabiskan waktu untuk belajar di luar kelas.

c. Sempitnya pandangan guru bahwa kegiatan belajar hanya terjadi di dalam kelas.

Banyak hal yang perlu dipikirkan oleh guru. Salah satunya adalah belajar di luar kelas yang akan menjadi daya tarik tersendiri sehingga banyak orang yang datang untuk menyaksikan. Pusat perhatian siswa akan langsumg tertuju kemana-mana karena posisi belajar mereka di tempat terbuka. Oleh karena itu, sebagai guru yang cerdas, diperlukan kiat-kiat tertentu untuk mengatasi kelemahan model pembelajaran outdoor learning. 


\section{KESIMPULAN}

Kesimpulan yang dapat diambil adalah bahwasannya nilai karakter dalam pembelajaran PKN dengan menerapkan metode Ourdoor Learning dapat terinternalisasi. Dengan alasan metode Outdoor Learning salah satu metode yang cukup bagus untuk meningkatkan kapasitas belajar peserta didik dan menjadikan peserta didik lebih memahami objek- objek yang dihadapi daripada hanya belajar didalam kelas. Dengan adanya penerapan Outdoor Learning peserta didik juga dapat secara langsung mengaplikasikan pengetahuan yang sudah dimiliki dan dapat membuat peserta didik lebih tertantang untuk mempelajarinya. Metode Outdoor Learning yang bertombak pada kegiatan Outdoor dapat menjadi jembatan antara teori didalam buku dan kenyataan yang ada. Kualitas peserta didik akan meningkat karena pembelajaran dengan situasi kenyataan masuk ke dalam ingatan jangka panjang. 


\section{BAB 8}

\section{Pengembangan Pembelajaran Pkn Sd Kelas \\ 1,2,3 (Kelas Rendah) Melalui Pendekatan Induktif/ Deduktif Dan Ekspository}

\section{CP-MK Capaian Pembelajaran Mata Kuliah :}
A. Mahasiswa dapat memahami Tinjauan Umum Tentang Pendekatan Induktif
B. Mahasiswa dapat mendeskripsikan Tinjauan Umum Tentang Pendekatan Deduktif
C. Mahasiswa dapat mendeskripsikan Tinjauan Umum Tentang Pendekatan Ekspository

Dalam dunia pendidikan, keberhasilan seorang siswa salah satunya yaitu tergantung pada cara mengajar gurunya. Setiap anak mempunyai kemampuan yang berbeda-beda dalam menerima pembelajaran. Ada yang dengan cepat mereka memahami materi yang disampaikan oleh gurunya dan ada mereka yang susah dalam memahami materi dari gurunya. Semua itu karena tingkat kecerdasan anak yang berbeda-beda. Andaikan anak mempunyai kemampuan sama, maka guru tidak memerlukan tenaga yang ekstra dalam mengajar dan mendidik. Sebelum melakukan pembelajaran, guru hendaknya menentukan pendekatan pembelajaran yang akan digunakan kepada siswanya sesuai dengan tujuan pembelajaran yang ingin dicapainya. Pendekatan pembelajaran adalah cara pandang yang ditempuh oleh guruatau siswauntuk mencapai tujuan proses 
pembelajaran. Pandangan ini masih bersifat umum. 
Pendekatan pembelajaran adalah cara memandang terhadap pembelajaran (Sri,dkk 2014:1.23)

Pendekatan pembelajaran dibagi menjadi 2, yaitu pendekatan pembelajaran yang berpusat pada guru (teacher centered) dan pendekatan pembelajaran yang berpusat pada siswa (student centered). Pembelajaran yang berpusat pada guru yaitu dimana siswa hanya sebagai penerima informasi dari guru.Guru yang berperan aktif di pendekatan ini.Akibatknya siswa kurang aktif dan menjadikan siswa malas dalam mencari informasi sendiri karena informasi telah didapatkan dari gurunya.Perlu diketahui bahwa ilmu itu bisa kita dapatkan dari manapun.Melalui buku, guru, internet, dll tergantung dari kemauan kita mencari informasi dari berbagai sumber tersebut.Sedangkan pendekatan yang berpusat pada siswa, dalam pendekatan ini siswa dituntut untuk aktif dan menemukan informasi dengan caranya sendiri. Guru hanya sebagai fasilitator bagi siswa. Guru hanya mengarahkan siswa ketika siswa mempunyai konsep yang kurang tepat. Untuk macam-macam pendekatan yang kita bahas yaitu pendekatan induktif, deduktif, dan ekspository. Melalui pendekatan tersebut, nantinya kita dapat menentukan model pembelajaran apa yang cocok bagi pelajaranPendidikan Kewarganegaraan (PKn) khusunya kelas rendah yaitu pada kelas 1, 2, dan 3 .

\section{A. Tinjauan Umum tentang Pendekatan}


Induktif Pembelajaran dengan pendekatan induktif dimulai dengan melakukan mengamati terhadap hal-hal yang khusus dan menginterpretasikannya, 
menganalisis kasus, atau memberi masalah konstektual, peserta didik dimbing memahami konsep, aturan-aturan, dan prosedur-prosedur berdasar pengamatan peserta didik sendiri. (Musfiqon dan nurdyansyah, 2015:45)

Pada pendekatan induktif hal yang pertama kali dilakukan adalah suatu pengamatan, setelah itu barulah penarikan kesimpulan berdasarkan hasil pengamatan yang telah dilakukan.Pengajaran dalam pendekatan ini dimulai dari hal yang bersifat khusus ke hal-hal yang sifatnya umum. Proses pembelajaran dengan pendekatan ini yaitu mengajar dengan menyajikan suatu kasus atau memberi suatu masalah kepada siswa sesuai dengan kenyataan kehidupan sehari-hari kemudian siswa diminta menganalisis suatu kasus tersebut. Siswa akan dibimbing oleh guru yang disini sebagai fasilitator dalam memahami konsep, aturan- aturan, dan langkah-langkah berdasarkan pengamatan yang dilakukan oleh peserta didik sendiri. Sehingga siswa dapat memecahkan suatu kasus atau masalah dan menyimpulkan sendiri dari analisis kasus tersebut melalui sebuah pengamatan.

Beberapa contoh model pembelajaran dengan pendekatan induktif misalnya pembelajaran inkuiri, pembelajaran berbasis masalah, pembelajaran berbasis proyek, pembelajaran berbasis kasus, dan pembelajaran penemuan. 
(Musfiqon dan nurdyansyah, 2015:45). 
Model-model yang dapat digunakan dengan pendekatan induktif yaitu sebagai berikut;

1. Model pembelajaran inquiry

Inquiri adalah proses pencarian jawaban melalui serangkaian kegiatan intelektual. Kegiatan yang dilakukan yaitu mulai dari merencanakan, mendiskusikan, membuat hipotesis atau jawaban sementara, menganalisis, dan menafsirkan hasil dengan tujuan untuk mendapatkan sebuah konsep yang baru.

Alasan menggunakan pendekatan inquiry adalah membangkitkan rasa ingin tahu siswa, melibatkan siswa dalam kegiatan yang memerlukan keterampilan kognitif tingkat tinggi, memberikan pengalaman konkret bagi siswa (Amalia, 2008: 2.11).

Pendekatan inquiry ini sangat bermanfaat untuk siswa, antara lain yaitu membangkitkan rasa ingin tahu siswa. Pada proses pembelajaran siswa hanya diberikan sebuah masalah oleh guru kemudian guru mengarahkan apa saja yang harus dilakukan. Siswa lalu mencari informasi-informasi kemudian menganalisis permasalahan sehingga siswa dapat memecahkan masalah tersebut.siswa disini jelas terlibat langsung dalam pembelajaran. Siswa bersikap aktif bukan pasif.Melalui kegiatan pembelajaran dapat memberikan sebuah pengalaman nyata kepada siswa karena siswa terlibat langsung dalam pencarian solusi atas 
sebuah masalah. Siswa juga akan mengingatnya 
dengan mudah karena tersimpan dalam memori otak ingatan jangka panjang.

Contoh penerapan model pembelajaran inquirypada pelajaran $\mathrm{PKn}$ kelas III tentang kekayaan alam.Guru menampilkan sebuah contoh kekayaan alam yang ada di Indonesia misalnya, gambar gunung, lautan, hutan, dll. Kemudian siswa mendiskusikan berada dimana saja kekayaan alam tersebut dan cara merawatnya. Sehingga nanti akan dapat disimpulkan bahwa Indonesia ini kaya akan kekayaan alamnya yang tersebar pada wilayah-wilayah tertentu. Dengan begitu siswa akan memiliki rasa bangga menjadi anak Indonesia.

2. Model pembelajaran berbasis masalah

Model pembelajaran berbasis masalah atau Problem Based Learning yaitu model pembelajaran yang menggunakan sebuah masalah yang terjadi dalam dunia nyata atau sesuai dengan kenyataan yang sedang terjadi disekitar lingkungan kita sebagai topik pembahasan pembelajaran bagi peserta didik, kemudian mereka diharapkan dapat menyelesaikan masalah secara bijak melalui pengetahuan yang diperolehnya.Contoh penerapan model pembelajaran berbasis masalahpelajaran PKn Kelas rendah yaitu kelas II dengan materi tentang mengenalkan sikap demokratis kepada siswa. Siswa diminta untuk melakukan musyawarah dengan 
kelompoknya.Setiap kelompok diberi satu permasalahan yang sesuai kenyataan yang terjadi dilingkungan sekitar kemudian 
anggota kelompok mendiskusikan bagaimana solusi yang tepat.

3. Model pembelajaran berbasis proyek

Pada model pembelajaran proyek, siswa akan lebih aktif dalam kegiatan proses pembelajaran. Mereka merancang sebuah produk, lalu produk yang mereka buat selama proyek memberikan hasil yang nyata dapat diukur oleh guru dalam pembelajarannya. Guru berperan sebagai fasilitator. Ketika siswa bekerja di dalam tim mereka akan melakukan kegiatan merencanakan, mengolah atau mengorganisasi, negoisasi atau tawar menawar dalam hal ini yaitu saling bertukar pikiran dengan tim dan menghargai setiap pendapat, dan menentukan penanggung jawab disetiap tugas. Contoh penerapan model pembelajaran berbasis proyek yaitu pada mata pelajaran PKN kelas II materi tentang sikap cinta lingkungan.Siswa diberi suatu alat dan bahan misalnya sampah atau barang-barang bekas.Setiap kelompok disuruh membuat daur ulang dari barang bekas itu agar menjadi sebuah karya.Sehingga siswa secara tidak langsung telah memelihara lingkungan alam.

4. Model pembelajaran berbasis kasus

Case Based Learning atau model pembelajaran berbasis kasus, dalam proses pembelajaran siswa mendiskusikan, mendebat, 
dan mengambil kesimpulan. Siswa dapat belajar dari kasus dengan begitu mereka akan memperoleh pengalaman yang berharga yang dapat digunakan di kemudian hari.Contoh penerapan 
model pembelajaran berbasis kasus pada pelajaran PKnKelas III materi tentang harga diri. Siswa diberi suatu kasus tentang harga diri.Misalkan diberikan sebuah kasus tentang perilaku yang tidak baik yaitutidak jujur karena takut dimarahain ibu sebab telah memecahkan vas bunga dirumah.Ketika itu siswa diminta untuk mendiskusikan bersama temannya bagaimana tanggapan mereka.Dari sebuah tanggapan tersebut muncullah sebuah kesimpulan atau solusi.

5. Model pembelajaran penemuan

Brunner beranggapan bahwa model belajar penemuan sesuai dengan hakiki manusia yang mempunyai sifat untuk selalu ingin mencari ilmu pengetahuan secara aktif, memecahkan masalah, dan informasi yang diperolehnya, serta akhirnya akan mendapatkan pengetahuan yang bermakna. (Amalia, 2008: 1.26).

Model pembelajaran ini sesuai dengan sifat manusia yaitu rasa ingin tahu yang tinggi. Mereka selalu ingin tahu tentang apa yang belum mereka ketahui sebelumnya. Ketika mereka telah mempunyai keinginan akan hal yang belum mereka pahami maka mereka akan berusaha mencari tahu informasi-informasi yang berkaitan dengan hal yang mereka cari hingga akhirnya mereka dapat menemukan masalah dan juga 
merekalah yang menyelesaikannya. Sehingga mereka menemukan sebuah ilmu yang bermakna dengan usaha mereka sendiri.Dalam pembelajaran, model penemuan 
ini sering disebut dengan discovery teaching.Model pembelajaran ini mempunyai ciri yaitu keterlibatan guru hanya sedikit.Mereka hanya sebagai fasilitator saja. Siswalah yang harus berperan aktif dalam proses pembelajaran. Guru tidak akan memberikan sebuah konsep atau teori namun siswalah yang diminta untuk mengumpulkan informasi-informasi sendiri sehingga akan menemukan sebuah konsep atau teori baru melalui penemuannya.

(Amalia, 2008: 1.27)Tiga ciri utama pembelajaran penemuan menurut Bruner, yaitu

1. Keterlibatan siswa dalam proses belajar

2. Peran guru adalah sebagai seoarang penunjuk (guide) dan pengarah bagi siswanya yang mencari informasi. jadi guru bukan sebagai penyampai informasi

3. Umumnya dalam proses pembelajaran digunakan barang-barang nyata.

Point pertama menjelaskan bahwa ciri-ciri model pembelajaran ini yaitu siswa yang terlibat penuh dalam proses pembelajaran. Mereka akan mencari dan mengumpulkan informasi-informasi sendiri sehingga mereka nanti dapat memecahkan masalahnya sendiri dan menemukan sebuah konsep sendiri.Selanjutnya ciri model ini yaitu guru hanya mengarahkan siswa ketika proses belajar. Guru mengarahkan siswa ketika mereka hendak 
mencari informasi, memberikan sebuah intruksi 
atau petunjuk ketika mereka dirasa kesulitan sehingga membutuhkan bimbingan dari seorang guru. Ketika siswa menemukan konsep-konsep yang salah maka tugas guru adalah membimbing dan mengarahkan siswa sehingga mereka masih tetap tekontrol dalam pengawasan guru walaupun mereka mencari pengetahuan sendiri melalui berbagai sumber.Ciri yang terakhir yaitu bahwa dalam pembelajaran ini sebaiknya menggunakan barang-barang nyata atau benda konkret sehingga dapat memudahkan siswa dalam proses belajarnya. Perlu diingat bahwa anak pada usia ini masih dalam tahap operasional konkret.

Ada dua macam model pembelajaran penemuan, yaitu model pembelajaran penemuan murni dan model pembelajaran penemuan terarah. (Amalia, 2008: 1.28)

Pada model pembelajaran penemuan murni ini guru tidak sama sekali memberikan intruksi atau arahan tentang cara pengerjaan kepada siswa. Jadi siswa benar-benar menemukan penemuannya sendiri. Ada kemungkinan bahwa penemuan suatu kelompok dengan kelompok yang lain berbeda. Sedangkan penemuan terarah yaitu guru memberi arahan kepada siswa tentang apa yang harus dilakukannya. Jadi siswa mengetahui langkah-langkah pembelajaran yang akan 
dilakukannya. 
Perlu diketahui bahwa untuk anak SD kelas awal (usia anak 6-7 tahun), tujuan pembelajaran discovery untuk mengembangkan keterampilan memasang dan merancang alat serta keterampilan mengobservasi, bukan untuk menemukan generalisasi secara ilmiah. (Amalia, 2008: 2.12)

Untuk kegiatan penemuan yang dilakukan anak Sd khususnya kelas rendah masihlah sangat sederhana. Mereka diharapkan dapat merancang alat dan mengobservasinya bukan sampai tahap menemukan sebuah konsep maupun kesimpulan.Dalam mengembangkan model pembelajaran discovery guru membentuk sebuah kelompok dan menunjuk salah satu siswa sebagai pemimpin (yang bertanggung jawab terhadap kegiatan kelompok).Contoh penerapan model pembelajaran penemuan pada pelajaran PKn Kelas I materi tentang perbedaan jenis kelamin. Salah satu Siswa perempuan dan laki laki disuruh ke depan kelas sebagai peraga. Siswa yang lain disuruh unruk mendiskusikan perbedaan-perbedaan yang ada pada temannya yang berdiri di depan. Kemudian guru memimbing siswa untuk menyimpulkan, bahwa perempuan dan laki-laki itu berbeda.Penggunaan pendekatan induktif ini tepat digunakan apabila: 
1. Siswa telah mempunyai pengalaman yang berkaitan dengan mata pelajaran tersebut. siswa yang telah mempunyai pengalaman maka akan jauh lebih mudah menangkap materi bila 
dibandingkan dengan temannya yang belum pernah mengetahuinya sama sekali. Pengalaman bisa didapatkan dari guru, atau dari informasi orang-orang terdekatnya sehingga mereka pernah mencobanya.

2. Pembelajaran ini mengajarkan keterampilan komunikasi antar pribadi, sikap atau perilaku, pemecahan masalah, dan pengambilan keputusan. Penggunaan pendekatan ini tepat apabila pelajaran yang disampaikan bertujuan untuk memecahkan masalah dan menemukan sebuah kesimpulan.

3. Guru mempunyai keterampilan fleksibel, terampil mengajukan pertanyaan-pertanyaan dengan sabar. Guru hendaknya bersifat luwes akan pengetahuannya maksudnya yaitu guru harus mempunyai pengetahuan yang lebih terhadap apa yang menjadi sub bahasan siswanya ketika itu, sehingga dapat memberikan pertanyaan- pertanyaan yang dapat memancing siswanya untuk memperoleh suatu pengetahuan baru.

4. Waktu yang tersedia cukup panjang. Dalam pendekatan induktif ini waktu yang panjang sangat diperlukan. Karena siswa berproses untuk menemukan sesuatu dan hal itu membutuhkan waktu yang tidak sedikit.

Langkah-langkahdalam pembelajaran induktif yaitu sebagai berikut: 
1. Menentukan suatu konsep yang akan dijadikan sebagai pokok bahasan dalam proses pembelajaran

2. Memberikan contoh yang spesifik kepada siswa sehingga memungkinkan mereka dapat menentukan hipotesis atau jawaban sementara atas permasalahannya

3. Menunjukkan bukti contoh lain yang dapat membenarkan atau menyangkal hipotesis yang telah dibuat siswa

4. Menyusun pertanyaan lalu menyimpulkan

Contoh penerapan pendekatan induktif ini dalam pembelajaran PK berupa cerita, gambar, video,dll yang terpenting dapat

dipahami oleh siswa. Karena siswa pada kelas ini masih berada pada tahap operasional konkret.Selanjutnya melaui contoh-contoh tersebut tanyakan kepada siswa kegiatan mana yang menunjukkan contoh hidup rukun dan yang tidak rukun. Setelah itu guru membimbing siswa mengambil sebuah kesimpulan tantang apa yang dimaksud dengan kerukunan.

Kelebihan pembelajaran Induktif:

1. Siswa lebih diberikan kesempatan untuk menemukan sebuah konsep sendiri sehingga masuk dalam ingatan jangka panjang siswa

2. Siswa lebih termotivasi sehingga siswa lebih semangat dalam belajar

3. Siswa lebih mandiri dalam pembelajaran 
Kekurangan pembelajaran induktif:

1. Membutuhkan waktu yang lama 

2. Terkadang hanya beberapa siswa saja yang aktif dan mendominasi

B. Tinjauan Umum tentang Pendekatan Deduktif

Pendidikan merupakan hal yang sangat penting bagi kehidupan se dahulu lulus dari jenjang pendidikan SD,SMP, dan SMA.

Barulah setelah itu kita dapat melanjutkan pendidikan ke jenjang perguruan tinggi.Beberapa hal yang medukung majunya tingkat pendidikan di Indonesia yaitu kualitas guru dalam mengolah pembelajaran di sekolah. Guru harus mempunyai strategi-strategi pembelajaran dan menentukan pendekatan pembelajaran yang cocok bagi peserta didiknya agar mereka dapat mengeikuti pembelajaran dengan mudah dan menyenangkan. Pendekatan pembelajaran adalah titik tolak yang digunakan guru dalam menentukan sebuah strategi dan model pembelajaran.

Ada beberapa macam pendekatan yang dapat digunakan guru dalam melakukan proses pembelajaran. Salah satunya adalah guru dapat menggunakan pendekatan deduktif. Pendekatan deduktif merupakan pendekatan yang menggunakan logika untuk menuntut peserta didik dalam berfikir yang kreatif. Pada pendekatan ini dimulai dari Guru menjelaskan hal yang besifat umum terlebih dahulu kemudian ke yang bersifat khusus.

Pendekatan deduktif adalah proses penalaran yang bermula dari keadaan umum ke keadaan yang khusus sebagai pendekatan pengajaran 
yang bermula dari dengan menyajikan atura, prinsip umum diikuti dengan contoh contoh khusus atau penerapan aturan. Dalam pendekatan deduktif 
menjelaskan hal yang berbentuk teoritis ke bentuk realitas. Disini guru menjelaskan teori teori yang ditemukan para ahli, kemudian menjabarkan kenyataan yang terjadi atau bis mengambil contoh (Sagala,2010).

Pada pendekatan deduktif ini guru awalnya menjelaskan sebuah teori-teori terlebih dahulu kepada peserta didik yang dikaitkan dengan kenyatan-kenyataan yang sedang terjadi disekitar. Kemudian guru member suatu bentuk contoh kepada siswa sesuai apa yang telah dijelaskannya. Adapun langkah - langkah yang harus dilakukan seorang guru sebelum menggunakan pendekatan Deduktif ini adalah sebagai berikut :

1. Seorang guru harus menyusun sebuah konsep atau materi terlebih dahulu yang akan diajarkan pada peserta didik

2. Guru menjelaskan sebuah konsep yang telah ditentukan tadi dari yang bersifat umun kemudian disertakan pemberian contoh konkret kepada peserta didik

3. Guru menampilkan contoh yang bersifat khusus dengan dibantu media pembelajaran dalam penyampaiannya agar siswa lebih memahami dan mengaitkan antara hal yang khusus ke umum

4. Guru menyampaikan bukti-bukti yang mendukung atau menolak kesimpulan bahwa keadaan umum itu adalah gambaran dari keadaan khusus. 
Kelebihan dari pendekatan Deduktif adalah sebagai berikut: 
1. Tidak membutuhkan waktu yang banyak

2. Teori-teori atau rumus yang telah diperoleh dapat langsung diterapkan ke dalam soal atau kesuatu hal yang bersifat konkret

3. Tidak membutuhkan berbagai perlengkapan

Kelemahan dari pendekatan Deduktif adalah sebagai berikut :

1. Seringkali peserta didik mengalami kesulitan karena mereka baru memahami konsep

2. Peserta didik kesulitan dalam memahami pembelajaran yang diberikan karena siswa hanya menerima sebuah konsep yang disajikan oleh gurunya. Mereka hanya sebagai pendengar informasi yang disampaikan gurunya

3. Siswa kurang mandiri karena semua konsep telah di jelaskan gurnya

4. Seringkali pembelajaran masuk dalam ingatan jangka pendek siswa. Karena siswa tidak telibat langsung dalam proses pembelajaran atau dalam penemuan sebuah konsep materi

\section{Tinjauan Umum tentang Pendekatan Ekspository}

Indonesia merupakan salah satu Negara yang memiliki kualitas pendidikan yang cukup bagus dengan biaya pendidikannya yang tidak terlalu mahal. Banyak sekolah-sekolah di Indonesia yang berstandar namun biayannya tidak semahal sekolah-sekolah yang ada di Negara lain. Salah satu faktor yang mendukung majunya pendidikan di Indonesia dan keberhasilan 
dalam mencapai tujuan pembelajaran adalah guru yang profesional. 
Guru yang profesional dituntut untuk bisa menampilkan keahliannya didepan kelas. Salah satu keahlian tersebut yaitu kemampuanmenyampaikan pelajaran kepada siswa. Untuk dapat menyampaikanpelajaran dengan baik efektif dan efisien, guru perlu mengenal berbagai jenisstrategi pembelajaran sehingga dapat memilih strategi manakah yang paling tepat untuk mengajarkan suatu bidang studi tertentu. Strategi pembelajaran disusun berdasarkan suatu pendekatan tertentu. Untuk bisa menentukan pendekatan yang cocok untuk dapat diterapkan dalam kelas yaitu guru harus mengetahui kondisi kelas terlebih dahulu kemudian analisis kebutuhan siswa, karakteristik siswa, tujuannya untuk apa, untuk mata pelajaran apa, pemilihan strategi yang sesuai, model yang cocok, serta media pembelajaran yang pas digunakan untuk kelas tersebut.Maka munculah sebuah pendekatan, pendekatan adalah seperangkat pengetahuan yang benar-benar disusun secara rapi untuk digunakan guru dalam menentukan sebuah strategi, metode, dan teknik dalam mencapai prestasi atau hasil tertentu dengan tujuan yang telah di tetapkan. Pendekatan sangat membantu guru dalam melaksanakan kegiatan belajar mengajar. Dari pendekatan guru bisa menentukan strategi apa yang cocok digunakan, metode yang pas dengan karakteristik siswa, dan dalam menentukan teknik teknik untuk mencapai hasil belajar siswa. 
yang disusun secara sistematis digunakan guru dalam dalam menentukan strategi, metode, dan teknik (prosedur) dalam mencapai target atau hasil 
tertentu sesuai dengan tujuan yang telah ditetapkan."(Sri Anita W: 1.2).

Pendekatan-pendekatan sangat banyak sekali macamnya. Salah satunya adalah pendekatan Ekspositori. Pendekatan ekspositori ini adalah sebuah bentuk pendekatan pembelajaran yang berorientasi pada guru. Dikatakan seperti itu karena dalam pendekatan ekspositori ini guru sangat berperan penting. Melalui pendekatan ini guru menyampaikan materi pembelajaran secara kompleks dengan harapan materi yang disampaikan guru bisa dikuasai siswa dengan baik.

Pendekatan ekspositori ini cocok untuk di terapkan bagi peserta didik khusunya kelas rendah, yaitu kelas 1, 2, dan 3. Hal ini dikarenakan karakterisitik peserta didik kelas rendah yang masih butuh pengarahan dari guru. Sehingga pembelajaran akan menjadi lebih baik dan terkondisikan apabila guru yang melakukan semua kegiatan pembelajaran, seperti menjelaskan semua materi. Akan tetapi siswa tetap diminta untuk memperhatikan penjelasan guru. Harapan guru dengan menggunakan atau menerapkan pendekatan ini supaya para siswa dapat memperoleh informasi dan pengetahuan baru.

"Dari hasil penelitian Edwin Fenton diketahui bahwa strategi "Expotition" (ekspositori), yang berarti guru hanya memberikan informasi yang 
berupa teori, generalisasi, hukum atau dalil beserta bukti-bukti yang mendukung. Siswa hanya menerima saja 
informasi yang diberikan oleh guru. Pembelajaran telah diorganisasikan oleh guru sehingga siap disampaikan kepada siswa dan siswa diharapkan belajar dari informasi yang diterimanya itu, pembelajaran itu disebut ekspositori." (Sri Anita W: 1.6)

"Suatu saat guru dapat menggunakan pendekatan ekspositori dengan metode ekspositori pula dan metode pembelajaran yang digunakan oleh guru dapat digambarkan sebagai berikut: ceramah, tanya jawab, resitasi, diskusi, studi kasus, eksperimen." (Sri Anitah W: 1.7).

\section{Metode - Metode yang Bisa digunakan dalam Pendekatan Ekspositori}

\section{Ceramah}

Cara mengajar yang paling tradisional dan telah lama dijalankan dalam sejarah Pendidikan ialah cara mengajar dengan ceramah. Sejak dahulu guru dalam menyalurkan ilmu pengetahuannya pada peserta didik yaitu dengan cara lisan atau disebut juga ceramah. Cara ini memang kadang membosankan, maka dalam pelaksanaannya memerlukan keterampilan tertentu, supaya dalam menyajikan materi pelajaran tidak membosankan dan bisa menarik perhatian siswa. Biasanya guru menggunakan teknik ceramah bila memiliki tujuan agar siswa 
mendapatkan informasi tentang suatu pokok atau persoalan tertentu. Memang hal itu wajar digunakan bila sekolah itu tidak memiliki bahan bacaan tentang masalah yang akan dibicarakan 
dan apabila sekolah memili jumlah siswa tiap kelas yang sangat banyak sehingga sulit untuk menggunakan teknik atau metode yang lain kecuali ceramah untuk bisa menjaungkau jumlah siswa sebanyak itu.

"Cara mengajar dengan ceramah
merupakan suatu cara mengajar yang
digunakan untuk menyampaikan
keterangan atau informasi, atau uraian
tentang suatu pokok persoalan serta
masalah secara lisan." (Roestiyah,
1988:137)

\section{Tanya Jawab}

Kalau siswa mendengarkan ceramah terus menerus, maka akan mengantuk dan bosan. Lama kelamaan perhatiannya menurun, apalagi bila si penceamah suara dan ucapan kata - katanya tidak menarik. Maka untuk menciptakan kehidupan interaksi belajar mengajar perlu guru menimbulkan teknik tanya jawab. Yang bertujuan agar siswa bisa mengerti atau mengingat - ingat tentang fakta yang dipelajari, didengar ataupun dibaca, sehingga mereka memiliki pengertian yang mendalam tentang fakta itu. Dalam metode tanya jawab ini pertanyaan yang dilontarkan guru pasti saja pertanyaan - pertanyaan yang ada hubungannya dengan materi pelajaran yang diajarkan guru dengan demikian pengetahuan siswa tentang 
pelajaran tersebut akan lebih meluas dan mendalam.

"lalah suatu teknik untuk memberi motivasi pada siswa agar bangkit pemikirannya untuk bertanya, selama mendengarkan pelajaran; 
atau guru yang mengajukan pertanyaan pertanyaan itu, siswa yang menjawab." (Roestiyah, 1988:129)

\section{Resitasi}

Kegiatan interaksi belajar mengajar harus selalu ditingkatkan. Dengan banyaknya kegiatan pembelajaran disekolah, dalam usaha untuk meningkatkan mutu peserta didik, maka sangat menyita waktu siswa untuk melaksanakan kegiatan belajar tesebut. Untuk mengatasi keadaan tersebut guru perlu memberikan tugas - tugas diluar jam pelajaran. Karena jika hanya menggunakan seluruh jam pelajaran yang ada untuk setiap mata pelajaran hal tersebut tidak akan mencukupi tuntutan luasnya pelajaran yang dibahas. Dengan demikian perlu diberikan tugas - tugas sebagai selingan untuk variasi dam pembelajaran ataupun dapat berupa pekerjaan rumah. Tugas semacam itu bisa bisa dikerjakan siswa diluar jam pelajaran, dirumah maupun sebelum pulang sekolah, sehingga bisa dikerjakan bersama teman.

"Metode Resitasi atau pemberian tugas biasanya digunakan dengan tujuan agar siswa memiliki hasil belajar yang lebih mantap, karena siswa melaksanakan latihan - latihan selama melakukan tugas; sehingga pengalaman siswa dalam mempelajari sesuatu dapat lebih terintegrasi." (Roestiyah, 1988:132). 


\section{Diskusi}

Teknik diskusi adalah salah satu teknik belajar mengajar yang dilakukan oleh seorang guru disekolah. Didalam diskusi ini proses interaksi antara dua tau lebih individu yang terlibat, saling tukar menukar pengalaman, informasi, memecahkan masalah, dapat terjadi semua aktif tidak ada yang pasif sebagai pendengar saja.

\section{Studi Kasus}

Dalam kehidupan sehari - hari banyak sekali persoalan - persoalan atau kasus yang dihadapi yang perlu untuk dipecahkan. Kasus kasus tersebut kadang

- kadang berat dan sulit, sehingga untuk pemecahannya memerlukan waktu yang lama. Tetapi bisa juga kasus itu ringan sehingga mudah dan cepat dapat terselesaiakan. Dalam kegiatan pembelajaran ketika guru mengajar dengan cara yang ditemui dalam kehidupan sehari - hari itu bisa digunakan juga sebagai cara dalam menyajikan pelajaran di dalam kelas. Hal tersebut disebut studi kasus. Misalnya: Tino dan 6 orang temannya di kelas III mengalami kecelakan waktu pulang sekolah. Hal itu di bahas Mengapa mereka kecelakan?, Apa sebabnya kecelakan dialami di kelas III?, Bagaimana cara mengatasinya?, Bagaimana cara menghindari selanjutnya dan seterusnya?.

"Studi kasus atau teknik secara kasus 
diartikan sebagai cara menyajikan pelajaran dengan memanfaatkan kasus yang ditemui anak, digunakan sebagai bahan pelajaran kemudian kasus tersebut dibahas bersama untuk 
mendapatkan penyelesain atau jalan keluar." (Roestiyah, 1988:93).

\section{Eksperimen}

Karena kemajuan teknologi dan ilmu pengetahuan, maka segala sesuatu memerlukan sebuah percobaan atau penelitian. Begitu juga dengan cara mengajar guru di dalam kelas digunakan teknik eksperimen tujuannya agar siswa mampu mencari dan menemukan sendiri berbagai jawaban atas persoalan - persoalan yang ditemui atau dihadapinya dengan mengadakan atau melakukan percobaan sendiri. Siswa akan bisa berpikir dengan cara yang ilmiah atau berpikir ilmiah. Dengan eksperiman siswa bisa menemukan bukti kebenaran dari teori sesuatu yang dipelajarinya.

"Salah satu cara mengajar, dimana siswa melakukan suatu percobaan tentang sesuatu hal; mengamati prosesnya serta menuliskan hasil percobaannya, kemudiah hasil pengamatan itu disampaikan ke kelas dan diealuasioleh guru." (Roestiyh, 1988:80). 


\section{Model Pembelajaran Cooerative}

Pada model cooperative learning penataan kelas harus diperhatikan dengan baik misalnya dalam penataan ruang kelas perlu memperhatikan prinsip - 
prinsip tertentu. Bangku perlu ditata sedemikian ruma sehingga semua siswa dapat memperhatikan guru atau melihat papan tulis dengan jelas, serta dapat melihat rekan - rekan kelompoknya dengan baik. Kelompok - kelompok yang telah dibentuk ini dapat berada dalam posisi dekat satu sama lain tetapi tidak mengganggu antara satu kelompok dengan kelompok lainnya.

Dalam belajar PKN misalnya biasanya siswa dihapkan pada latihan soal - soal atau pemecahan masalah. Pembelajaran kooperatif menjadi solusi bagi penyelesaian tugas - tugas tersebut karena setiap siswa dapat bekerja sama dan tolong - menolong mengatasi tugas yang dihadapinya. Selain itu dalam belajar kooperatif, siswa terlibat aktif pada proses pembelajaran sehingga memberikan dampak yang positif terhadap interaksi dan komunikasi yang berkualitas sehingga dapat memotivasi siswa meningkatkan prestasi belajarnya.

Langkah - langkah Model Pembelajaran Kooperatif

\begin{tabular}{|l|l|l|}
\hline $\begin{array}{l}\text { FAS } \\
\text { KE- }\end{array}$ & INDIKATOR & AKTIVITAS / KEGIATAN GURU \\
\hline & & Guru mengomunikasikan semua \\
\hline
\end{tabular}




\begin{tabular}{|l|l|l|}
1 & $\begin{array}{l}\text { Menyampaikan tujuan dan } \\
\text { memotivasi siswa }\end{array}$ & $\begin{array}{l}\text { tujuan pelajaran yang ingin dicapai } \\
\text { pada pelajaran tersebut } \\
\text { dan } \\
\text { memotivasi siswa untuk belajar } \\
\text { dengan baik. }\end{array}$ \\
\hline
\end{tabular}




\begin{tabular}{|c|c|c|}
\hline 2 & Menyajikan informasi & $\begin{array}{l}\text { Guru menyampaikan informasi } \\
\text { kepada siswa dengan jalan } \\
\text { demonstrasi atau lewat bahan } \\
\text { bacaan. }\end{array}$ \\
\hline 3 & \begin{tabular}{lrr}
\multicolumn{3}{l}{ Mengorganisasikan } \\
siswa & ke & dalam \\
kelompok & - & kelompok \\
belajar & &
\end{tabular} & $\begin{array}{l}\text { Guru menjelaskan kepada siswa } \\
\text { bagaimana caranya membentuk } \\
\text { kelompok belajar dan membantu } \\
\text { setiap kelompok agar melakukan } \\
\text { tugas belajar secara efisien. }\end{array}$ \\
\hline 4 & $\begin{array}{l}\text { Membimbing } \\
\text { kelompok bekerja dan } \\
\text { belajar }\end{array}$ & $\begin{array}{l}\text { Guru membimbing kelompok } \\
\text { belajar pada saat mereka } \\
\text { mengerjakan tugas. }\end{array}$ \\
\hline 5 & Evaluasi & $\begin{array}{l}\text { Guru mengevaluasi hasil belajar } \\
\text { tentang materi yang telah dipelajari } \\
\text { atau masing - masing kelompok } \\
\text { mempresentasikan hasil kerjanya. }\end{array}$ \\
\hline 6 & Memberikan penghargaan & $\begin{array}{l}\text { Guru mencari cara untuk } \\
\text { menghargai upaya atau hasil } \\
\text { belajar individu maupun kelompok } \\
\text { secara proporsiaonal. }\end{array}$ \\
\hline
\end{tabular}

"Manfaat penggunaan model cooperative learningdiantaranya:

1) Mengajarkan siswa untuk mengurangi ketergantungannya pada guru dan lebih percaya pada kemampuan diri mereka;

2) Mendorong siswa untuk mengungkapkan ide - 
ide secara verbal; 
3) Membantu siswa untuk belajar bertanggun jawab dan belajar menerima perbedaan;

4) Membantu siswa memperoleh hasil belajar yang baik, meningkatkan hubungan sosial, hubungan positif antar individu, memperbaiki keterampilan dalam mengatut wakktu."(Jihad, 2015:144). 


\section{KESIMPULAN}

Dalam pembelajaran PKn SD kelas 1, 2, 3 (rendah) terdapat beberapa pendekatan pembelajaran yang cocok untuk diterapkan. Dan dalam pendekatan tersebut terdapat pula model - model pembelajaran. Diantaraya, yaitu : (a) pendekatan induktif, model pembelajaran dalam pendekatan induktif yaitu Model pembelajaran inquiry, Model pembelajaran berbasis masalah, Model pembelajaran berbasis proyek, Model pembelajaran berbasis kasus, Model pembelajaran penemuan; (b) pendekatan deduktif; (c) pendekatan ekspository, model pembelajaran dalam pendekatan ekspository adalah model pembelajaran cooperatie.Dari macam pendekatan tersebut cocok digunakan dalam pembelajaran yang disesuaikan dengan tujuan yang hendak dicapai dan kondisi peserta didik. 


\section{BAB 9}

Pengembangan Pembelajaran Pkn Di Sd "Perencanaan Sebuah Pembelajaran Berbasis E-Learning Pkn Sd Kelas Tinggi 4,5,6 Yang Inovatife Dan Berkarakter"

Capaian Pembelajaran (CP) :
A. Mahasiswa dapat memahami Tinjauan Umum Tentang E- Learning
B. Mahasiswa dapat mendeskripsikan Pembelajaran Pkn Kelas Tinggi Berbasis E-Learning
C. Mahasiswa dapat mendeskripsikan Pelaksanaan Pembelajaran Berbasis E Learning
D. Mahasiswa dapat menganalisis Kendala-Kendala Penerapan E-Learning Education
E. Mahasiswa dapat menganalisis Upaya Yang Dilakukan Untuk Mengatasi Kendala-Kendala

\section{A. Tinjauan Umum Tentang E-Learning}

Kemajuan ilmu pengetahuan dan teknologi banyak memiliki dampat positif atau bernilai baik dalam bidang pendidikan di Indonesia. Teknologi Informasi dan Komunikasi (TIK) sangat diperlukan dalam dunia pendidikan baik pendidikan formal, informal, dan non formal terutama internet. Internet dapat digunakan sebagai alat untuk mencari suatu informasi dari berbagai sumber dan sebagai alat 
komunikasi.Pembelajaran harus menggunakan suatu teknologi-teknologi yang modern agar pembelajaran tersebut dapat meningkatkan minat peserta didik dalam belajar. Media yang bisa digunakan dalam proses 
pembelajaran yang inovativ dan berkarakter yaitu pembelajaran yang berbasis E-Learning.

E-Learning adalah proses pembelajaran yang memanfaatkan teknologi informasi dan komunikasi (TIK) secara sistematis dengan mengintegrasikan semua komponen pembelajaran, termasuk interaksi pembelajaran lintas ruang dan waktu, dengan kualitas yang terjamin. (Prof.Dr.Sulystyoweni Widanarko).

Maksud dari pengertian diatas adalah suatu pembelajaran yang membutuhkan media pembelajaran dan digunakan untuk memudahkan proses belajar mengajar. Proses pembelajaran harus dilakukan secara menarik dan tidak bersifat monoton. Maka dari itu, pembelajaran harus bisa memanfaatkan teknologi informasi dan komunikasi secara sistematis yang menjadikan pembelajaran tersebut berinovativ dan berkarakter bagi peserta didik kelas tinggi.

Potensi-potensi teknologi pendidikan adalah sebagai berikut :

1. Meningkatkan produktivitas pendidikan dengan cara:

a. Mempercepat tahap belajar (rate of learning)

b. Membantu guru untuk menggunakan waktunya secara lebih baik.

c. Mengurangi beban guru dalam menyajikan informasi, sehingga guru dapat lebih banyak membina dan mengembangkan minat belajar anak.

2. Memberikan kemungkinan pendidikan yang 
sifatnya lebih individual dengan cara :

a. Mengurangi control guru yang kaku dan tradisional. 
b. Memberikan kesempatan peserta didik berkembang sesuai kemampuannya.

3. Memberikan dasar yang lebih ilmiah terhadap pengajaran dengan cara :

a. Perencanaan program pengajaran yang lebih sistematis.

b. Pengembangan bahan pengajaran yang dilandasi penelitian tentang perilaku.

4. Lebih memantapkan pengajaran dengan cara :

a. Meningkatkan kapabilitas manusia dengan berbagai media komunikasi.

b. Penyajian informasi dan data secara lebih konkrit.

5. Memungkinkan belajar secara seketika (immediacy of learning) karena dapat :

a. Mengurangi jurang pemisah antara pelajaran didalam dan diluar sekolah.

b. Memberikan pengetahuan langsung.

6. Memungkinkan penyajian pendidikan lebih luas, terutama adanya media massa dengan cara :

a. Pemanfaatan bersama (secara lebih luas) tenaga atau kejadian yang langka.

b. Penyajian informasi menembus batas geografi. Pendapat tersebut dinyatakan oleh (Ely, 1979:1-Arsip dari buku Teknologi Komunikasi Pendidikan oleh (Yusufhadi, 1986).

\section{B. Pembelajaran PKn Kelas Tinggi Berbasis E-Learning}

Komunikasi tidak hanya melalui secara langsung 
(tatap muka) namun, komunikasi juga dapat dilakukan dengan 
menggunakan teknologi. Misalnya e-mail, website, mailinglist dan lain-lain. Dapat juga digunakan sebagai alat komunikasi dinamis misalnya suara, gambar, dan video. Di dalam kurikulum KTSP 2006 dengan mata pelajaranPKn kelas tinggi terdapat beberapa standar kompetensi dan kompetensi dasar yang cocok menggunakan media pembelajaran yang berbasis E-Learning. Pembelajaran PKn SD kelas tinggi perlu adanya pembaharuan dalam menyampaikan materi pembelajaran, agar mudah difahami dan menarik minat peserta didik dalam mengikuti mata pelajaran PKn terutama pada kelas tinggi. Pembaharuan tersebut kita buat melalui elektronik.

Pada era sekarang teknologi sudah semakin canggih dan cepat berkembang bahkan dalam hitungan menit. Di setiap harinya teknologi selalu mengalami pembaruan. Dengan kemajuan teknologi yang cepat kita harus bisa memanfaatkan teknologi tersebut dengan baik. Agar kita tidak diperbudak oleh teknologi. Maka dari itu, pada pembelajaran PKn di SD kelas tinggi kita dapat memaksukkan teknologi kedalamnya yang bisanya disebut dengan pembelajaran yang berbasis E-Learning. E-Learning adalah pembelajaran yang menggunakan teknologi seperti komputer dan internet serta masih banyak lainnya. Dapat diartikan, bahawa pembelajaran berbasis E-Learning adalah suatu cara yang dilakukan dalam proses belajar mengajar dengan menggukan teknologi seperti komputer, internet serta memanfaatkan teknologi informatika.Kegiatan pembelajaran melalui perangkat 
elektronik komputer yang tersambungkan ke internet, dimana peserta didik berupaya memperoleh bahan belajar sesuai dengan kebutuhannya. Peserta didik dapat mencari dan menemukan informasi yang 
diperlukan dari sedemikian banyak summber informasi dengan cara efektif dan efisien.Dalam mendukung kelangsungan belajara dengan menggunakan medel pembelajaran berbasis $\mathrm{E}$ Learning ada beberapa sarana dan Prasarana E-learning for Education yang harus terpenuhi, diantaranya:Tiap-tiap kelas perlu 1 unit computer; Koneksi internet; Audio - Visual (TV, tape recorder); LCD, baik portable maupun permanenPSB (pusat sumber belajar) yang menyediakan layanan dan program pembelajaran berbasis ICT, menurut (Hisyam Zaini, 2008).

Penerapan metode ini dapat dilakukan dengan cara memberikan tugas pada siswa untuk mencari informasi yang berkaitan dengan kompetensi dasar atau topik yang sedang dipeljari atau dibahas, dan selanjutnya siswa mempresentasikan hasil pencarian tersebut di kelas.Proses pembelajaran E-learning :

1. Mencari materi pokok pembelajaran

a. Guru menyampaikan kompetensi dasar serta beberapa indikator kepada para siswa beserta situs intemet yang dapat dikunjungi berkenaan dengan kompetensi dasar serta indikator tersebut.

b. Siswa mendownload materi pokok pembelajaran yang sesuai dengan kompetensi dasar serta indikator yang disampaikan oleh guru pada situs yang telah ditunjukkan oleh guru, dalam hal ini siswa diberi kesempatan untuk mencari pada situs lain selain yang ditunjukkan oleh guru . 
c. Setelah mengedit apabila diperlukan, siswa mengirimkan hasil download tersebut ke web site atau email guru. 
d. Guru mengedit materi pokok yang dikirim oleh para siswa, mengeditnya, yaitu dengan mengurangi apabila mated yang dikirim oleh siswa apabila bahasannya terlalu luas, atau menambah apabila materi yang dikirim oleh siswa terialu ringkas pembahasannya, sehingga belum memenuhi indikator yang dikehendaki oleh guru.

e. Setelah di edit, guru mengirimkan ke alamat email siswa apabila materi pokok pembelajaran sudah disesuaikan indikator yang dikehendaki

2. Pelaksaanaan ulangan harian dan ulangan blok

a. Guru mempersiapkan bank soal, akan lebih bagus apabila soalnya cukup banyak namun masih dalam koridor indikatoryang dikehendaki oleh guru, sehingga soalnya dapat diacak agar masing masing peserta tidak sama persis soalnya, banksoal ini tentu harus di lengkapi dengan program pengacak soal, kunci jawaban serta skor yang akan di peroleh bagi masingmasing peserta.

b. Program ini hendaknya dilengkapi dengan $\mathrm{KKM}$, serta penjelasan untuk jawaban yang benar ataupun yang salah untukkeperiuan remidi lagi yang belum mencapai norma KKM.

c. Masing-masing siswa mempunyai nomor khusus, NIS misalnya, sebagai identitas siswa disamping nama ketika entri data.

d. Semua unit PC sudah tersambung secara LAN 
dengan server bagi guru, dimana bank soal maupun program program pendukung yang lain. 
E-Learning memiliki beberapa karakteristik dalam penerapannya dalam pemebelajaran, diantaranya: Memanfaatkan jasa teknologi informasi dan komunikasi berupa internet sehingga penyampaian pesan dan komunikasi guru dan siswa dapat di lakukan secara mudah dan cepat; Memanfaatkan media komputer seperti jaringan komputer ( digital media); Pendekatan pembelajaran yang mandiri; Menggunakan E-Learning, pembelajaran di tuntut untuk melepaskan ketergantungannya terhadap buku atau guru (teacher centered).

Bukan hanya memiliki karakteristik dalam mengimplikasikan pembelajaran yang berbasis E-learning. E- learning juga bermanfaat bagi siswa, guru dan sekolah. Manfaat untuk siswa sendiri ialah:

a. Pembelajaran dari mana dan kapan saja,

b. Bertambahnya Interaksi pembelajaran antara peserta didik dengan guru atau instruktur,

c. Menjangkau peserta didik dalam cakupan yang lebih luas lagi,

d. Mudah dalam penerimaan materi pembelajaran yang di berikan oleh guru.

Sedangkan manfaat untuk guru adalah :

a. Menghemat waktu proses belajar mengajar,

b. Mengurangi biaya pembelajaran (seperti harus membeli buku-buku dan sebagainya;)

c. Melatih peserta didik agar lebih mandiri dalam belajar 
Manfaat untuk sekolah adalah :

a. Tingkat kepercayaan stake holder (yayasan, orang tua, dan masyarakat) meningkat.

b. Memudahkan untuk memetakan guru pada program pelatihan lanjutan.

c. Prestasi sekolah meningkat.

d. Penggunaan E-learning memunculkan prestise bagi sekolah.

Pendidikan Kewarganegaraan adalah sebuah bidang kajian yang menyandarkan kajiannya pada hubungan antara warga negara dengan negara, serta Pendidikan Pendahuluan Bela Negara pada setiap pribadi manusia yang menyatakan dirinya sebagai warga negara Indonesia, pendapat diatas dikemukakan oleh (Lemhanas, 2001). Pendidikan Kewarganegaraan sangat memiliki peran penting guna meningkatkan pribadi, perilaku aset bangsa sejak dini. Serta dapat menjadikan warga negara yang baik dan mengurahi angka permasalhan yang terjadi pada sekitar kita maupun mengendalikan diri dengan baik sesuai dengan Pancasila.Tujuan pendidikan kewarganegaraan adalah untuk mengembangkan kemampuan peserta didik agar dapat tumbuh menjadi warga negara yang baik (good citizen), pendapat ini diungkapkan oleh (Fathurrohman, 2012). Sesuai dengan yang ditetapkan oleh Badan Standar Nasional Pendidikan (BSNP), tujuan mata pelajaran PKn adalah untuk memberikan kompetensi-kompetensi kepada siswa sebagai berikut:Berpikir secara kritis, rasional, dan kreatif dalam 
menanggapi isu kewarganegaraan yang terjadi di dalam negara maupun di luar negara; Berpartisipasi secara 
bermutu dan bertanggungjawab, dan bertindak secara cerdas dalam kegiatan bermasyarakat, berbangsa, dan bernegara. Dengan demikian mencerminkan bahwa siswa memiliki jiwa dan perilaku yang dapat dipertanggungjawabkan baik secara moral dan lisan; Berkembang secara positif dan demokratis untuk membentuk diri sendiri berdasarkan pada karakter-karakter masyarakat Indonesia agar dapat hidup bersama dengan bangsa-bangsa lain.; Berinteraksi dengan bangsa-bangsa lain dalam peraturan dunia secara langsung atau tidak langsung dengan memanfaatkan teknologi informasi dan komunikasi.

Paparan diatas, pembelajaran berbasis E-Learning dengan pembelajaran PKn pada kelas tinggi jika di kombinasikan akan mempermudah siswa dalam proses belajar mengajar serta siswa juga mudah mencari informasi yang mereka butuhkan. Karena siswa dituntut untuk berfikir kritis dan kreatif terutama dalam pembelajaran PKn kelas tinggi. Dengan menggunakan fasilitas yang sudah banyak tersedia di dalam era modern ini misalnya menggunakan media jaringan dalam memcari informasi yang dibutuhkan, dalam pembelajaran seperti ini disebut pembelajaran berbasis E-learning. E-Learning adalah salah satu wujud dari pembelajaran jarak jauh. Adapun perbedaan dan persamaan dari pembelajaran jarak jauh dengan pembelajaran online, pendapat tersebut dinyatakan oleh (Sharon, 2011).

Perbandingan antara belajar jarak jauh dengan belajar online 


\begin{tabular}{|l|l|}
\hline Pendidikan Jarak Jauh & Pembelajaran Online \\
\hline $\begin{array}{l}\text { Belajar melalui media } \\
\text { telekomunikasi-telepon, }\end{array}$ & $\begin{array}{l}\text { Pengajaran } \\
\text { disampaikan } \\
\text { melalui komputer, sering klai }\end{array}$ \\
\hline
\end{tabular}




\begin{tabular}{|l|l|}
\hline televisi. & $\begin{array}{l}\text { menggunakan jaringan dan } \\
\text { internet. }\end{array}$ \\
\hline $\begin{array}{l}\text { Komunikasi sering kali } \\
\text { bersifat satu arah. }\end{array}$ & $\begin{array}{l}\text { Komunikasi biasanya } \\
\text { bersifat dua arah. }\end{array}$ \\
\hline
\end{tabular}

Pendidikan jarak jauh dengan Pembelajaran online terdapat kesamaan dari keduanya, adapun kesamaannya: keduanya dapat digunakan sebagai bagian dari program pengajaran terorganisir.; keduanya dapat digunakan pada semua tingkatan (mulai dari SD dan diatasnya).; keduanya dapat digunakan dlam pendidikan formal dan informal.; keduanya dapat digunakan untuk disiplin ilmu.; keduanya melibatkan derajat pemisahan fisik yang berbeda-beda dari pembelajaran dan guru. Dari deskripsi diatas pendidikan jaraj jau dan pembelajaran sangat menguntungkan bagi siswa maupun guru, dengan kemudahan yang dimiliki kedua baik dalam mencari informasi dan masih banyak lainnya.

Siswa dan guru bisa meningkatkan belajar PKn di kelas denagn mengakses informasi dari sumber-sumber (database, perpustakaan, kelompok dengan minat khusus), berkomunikasi via komputer dengan siswa lainnya untuk memperkaya kajian mereka. Siswa juga menjadi lebih interaktif dan interest dalam pembelajaran $\mathrm{PKn}$. Karena pembelajaran ini menggunakan komputer yang memiliki kemampuan 
untuk menyampaikan informasi dalam sarana apapun (seperti cetakan, video, rekaman, audio dari suara dan musik) komputer telah menjadi perpustakaan yang tak terbatas. Serta siswa bebas mengeksdpresikan keinginan 
mereka dalam membuat atau pengeditan serta mengaplikasikan salah satu program atau fasilitas yang disediakan oleh komputer. Namun, guru tetap memantau tindakan siswanya agar tetap dalam jalur pembelajaran. Karena terdapat banyak isu penting yang terkait dengan belajar elektronik terutama mengenai penggunaan internet. Isu tersebut meliputi keamanan, pemantauan terhadap pemanfaatan oleh para siswa, kebijakan penggunaan yang bisa diterima, dan etika. Guru harus selalu mengawasi siswasiswinya karena kebanyakaan mereka masih belum paham betul tentang dunia internet.

\section{Pelaksanaan pembelajaran berbasis E Learning}

E-learning sangat banyak yang bisa digunakan sebagai dalam dunia pendidikan, pertama sebagai sumber materi pelajaran, contoh: Keutuhan Negara Kesatuan Republik Indonesia (NKRI), misal: sikap yang harus dimiliki untuk menjaga keutuhan bangsa : Guru menayangkan contoh- contoh sikap yang bisa menyatukan bangsa agar tetap bersatu padu dengan menggunakan gambar animasi (download di internet).Dengan demikian siswa lebih memahami lagi apa arti kata kesatuan dan bagaimana cara menjaga persatuan dan kesatuan tersebut. Materi-materi seperti tersebut di atas tersedia lengkap di internet. Materi tinggal dicari di internet dan dapat langsung ditayangkan dengan menggunakan LCD. Kedua sebagai presentasi siswa, baik tugas kelompok maupun tugas perorangan. Yang mampu mengaktifkan kreatifitas siswa dan menjadikan siswa yang memiliki 
keterampilan. Ketiga sebagai KBM oleh guru (agar pembelajaran lebih menarik). Dengan demikian guru lebih mudah dalam proses KBM dengan fasilitas yang 
sudah disediakan, guru tinggal mengolah dan menggunakan dengan baik.

\section{Kendala-Kendala Penerapan E-learning Education}

$\mathrm{P}$ enerapan pembelajaran $\mathrm{PKn}$ berbasis E-learning tidak semulus yang kita rencanakan. Kendala pasti akan ditemui dalam proses belajar mengajar. Ada beberapa kendala yang dialami dalam pembelajaran PKn yang berbasis E-learning, yaitu:

a. Belum semua guru mau menerima keberadaan Elearning.Para guru senior terkadang lebih nyaman dengan cara mengajar yang sudah mereka terapkan setiap harinya. Jika diganti dengan yang baru (E- learning) guru merasa kesulitan dapan menjalanjan proses pembelajaran.

b. Belum semua guru mampu menguasai dan menggunakan E-learning. Kenapa demikian? Karena masih ada guru yang belum bisa menggunakan teknologi IT dan kurangnya pelatihan-pelatihan pada tiap sekolah untuk para guru. Guru harus dapat bimbingan yang baik dan layak guna meningkatkan kualitas guru itu sendiri.

c. Beberapa media seperti LCD, wireless jumlahnya masih terbatas sehingga penggunaannya harus diatur. Fasilas yang kurang dapat menghambat proses pembelajaran. Sekolah harus memenuhi fasilitas untuk menunjang pembelajaran E-learning, jika sekolah tersebut ingin menerapkan pembelajaran berbasis E-learning di sekolahnya.

d. Harga media ICT masih mahal. Harga yang tidak 
murah juga faktor kendala untuk sekolah apaligi sekolah di 
pedesaan atau yang kurang pendanaannya. Perlu adanya bantuan dari pemerintah untuk pendidikan guna meningkan kualitas pendidikan di Indonesia.

\section{E. Upaya yang Dilakukan Untuk Mengatasi Kendala-Kendala}

Meningkatkan kualitas pendidikan di Indonesia sangat penting, karena penerus generasi bangsa dimulai sejak dini. Jadi para anak-anak Indonesia harus dibekali dengan berbagai pembelajaran terutama pembelajaran PKn yang berkualitas baik agar mereka paham betul Negara Indonesia yang mana Negara mereka sendiri. Upaya untuk mengatasi kendala yang menghambat pembelajaran PKn berbasis E- learning adalah:pertama dengan mengadakan pendekatan persuasif tentang pentingnya E-learning. Mengadakan penyuluhan tentang pembelajaran berbasis E-learning kepada sekolah, guru, serta siswa agar masyarakat di lingkup pendidikan paham dam pembelajaran tersebut. Kedua menjalin pola kemitraan dengan pihak-pihak yang peduli dengan pendidikan (kemitraan bisa dijalin dengan perusahaan yang beroperasi di sekitar lingkungan sekolah melalui program comunity development/comdev).Ketiga mengadakan pelatihan-pelatihan. Misalnya: pelatihan komputer program windows dan excel, pelatihan pebuaan bahan ajar dalam power point, pelatihan pembuatan e-mail., pelatihan pembuatan blog.Keempat mengupayakan media yang jumlahnya masih kurang (dapat menggunakan dana dari RAPB maupun BOS). Fasilitas sangat diperlukan di pembelajaran berbasis E-learning 
ini, sekolah harus menyediakan semua kebutuhan yang bisa mendukung pembelajaran berbasis E-learning. Agar pembelajaran berbasis E-learning ini berjalan sesuai rencana. 


\section{Kesimpulan}

Pembelajaran E-learning adalah pembelajaran yang menggunakan media teknologi elektronik dan juga internet. E-learning memudahkan pendidikan dalam menyampaikan materi pembelajaran dan mencari informasi secara luas serta peserta didik juga mudah dalam menangkap dan menerima materi pembelajaranyang disampaikan oleh pendidik. Pembelajaran PKn berbasis E-learning sangat menguntungkan, serta untuk mengikuti arus modernisasi dan juga memberi dampak positif bagi peserta didik serta pendidik dan peserta didik bisa mengakses internet. 
BAB 10
Pengembangan Model Penilaian Pkn Sd
(Teknik Tes Dan Non-Tes Serta Aspek Kognitif Dan
Non- Kognitif)

CP-MK Capaian Pembelajaran Mata Kuliah :
A. Mahasiswa dapat memahami Pengertian Penilaian Asesment Dalam Pembelajaran
B. Mahasiswa dapat mendeskripsikan Pengembangan Alat Penilaian Dalam Bentuk Tes Dan Non-Tes
C. Mahasiswa dapat mendeskripsikan Pengembangan Alat Penilaian Kognitif Dan Non-Kognitif

A. Pengertian Penilaian Asesment dalam Pembelajaran Penilaian adalah suatu kegiatan untuk membuatkeputusantentanghasil pembelajarandarimasingmasingsiswa,sertakeberhasilansiswadalam kelassecara keseluruhan.
Penilaianjugamerupakanindikatorkeberhasilan guru dalam proses pembelajaran (Supratiningsih dan Suharja,2006).

Dalam proses penilaian ini tidak hanya melibatkan siswa sebagai objek yang akan dinilai, akan tetapi juga melibatkan guru. Karena pada saat penilaian berlangsung, secara tidak langsung saat guru memberikan penilaian terhadap hasil belajar 
siswa maka guru tersebut juga sekaligus menilai apakah indikator pembelajaran yang ditetapkan guru sudah berhasil atau belum. Keberhasilan indikator ini bisa dilihat dari baik/kurangnya hasil penilaian dari guru yang diberikan kepada siswa. 


\section{B. Pengembangan Alat Penilaian dalam Bentuk Tes dan Non- Tes}

Sebagaimana diketahui sebelumnya, kita sebagai calon guru SD pasti sudah sangat mengerti dan faham tentang sistem penilaian pembelajaran di $\mathrm{SD}$, salah satu di antaranya penilaian pada mata pelajaran PKn dimana teknik penilaian tersebut bisa dilakukan menggunakan 2 cara, yaitu dengan menggunakan teknik tes dan teknik non-tes. Untuk mengetahui secara lebih jelas terkait dengan pengembangan alat penilaian pada kedua teknik tersebut, kami akan membahasnya secara lebih detail.

\section{Pengembangan Alat Penilaian dengan Teknik Tes}

Teknik tes merupakan suatu yang alat yang bersifat sangat sistematik apabila digunakan untuk mengukur perilaku-perilaku tertentu pada peserta didik. Teknik tes ini dibedakan menjadi 3 berdasarkan cara pelaksanaannya, antara lain :

\section{a. Tes Tertulis}

Tes tertulis merupakan alat penilaian yang dalam pelaksanaannya dilakukan secara tertulis. Tes secara tertulis ini dapat memberikan kesempatan yang sangat baik kepada siswa untuk berfikir secara lebih cermat dan teliti karena secara prosedural tes tertulis tidak memerlukan jawaban secara langsung, akan tetapi siswa akan 
dituntut untuk menuliskan hasil fikirannya sebagai sebuah jawaban. 


\section{b. Tes Lisan}

Berbeda dengan tes tulis, tes lisan disini pelaksanaannya dilakukan secara lisan. Di dalam tes lisan ini, baik pertanyaan yang diajukan oleh guru maupun jawaban yang diberikan oleh siswa semuanya dilakukan secara lisan. Tes lisan ini menuntut siswa untuk memberikan jawaban secara langsung, akan tetapi akan lebih baik lagi apabila siswa juga diberikan sedikit waktu untuk berfikir sebelum menyampaikan jawabannya. Masih kurangnya pemberian waktu kepada siswa sebelum mereka memberikan jawaban yang akhirnya mempengaruhi kualitas jawaban yang diberikan oleh siswa. Terkadang, siswa juga masih sering merasa nervous/grogi pada saat menghadapi tes lisan ini.

\section{c. Tes Perbuatan}

Tes pebuatan ini tentunya sangat berbeda dengan tes tertulis dan juga tes lisan. Pada tes perbuatan ini pengajuan pertanyaan serta pemberian jawabannya bisa dilakukan secara tertulis maupun lisan, misalnya saja praktik di Laboratorium, praktik kesenian, simulasi, dan deklamasi. Selain digunakan untuk mengetahui kemampuan intelektual anak, tes perbuatan ini juga dapat digunakan untuk mengetahui kemampuan gerakan fisik/psikomotor. 


\section{Pengembangan Alat Penilaian dengan Teknik Non- Tes}

Berbeda dengan teknik tes sebelumnya, pada teknik non-tes ini prosedur penilaiannya tidak se sistematik seperti yang ada dalam penilaian pada teknik tes. Akan tetapi, teknik non-tes ini memiliki kelebihan jika dibandingkan dengan teknik tes. Kelebihannya yaitu penilaian yang menggunakan teknik non-tes ini memiliki keakuratan apabila digunakan untuk mengetahui gambaran-gambaran mengenai karakteristik minat, sikap, maupun kepribadian siswa. Berdasarkan cara pelaksanaannya, teknik non-tes dapat dibedakan menjadi 5, antara lan :

\section{a. Skala sikap}

Skala sikap merupakan suatu alat penilaian yang digunakan untuk mengetahui sikap dari peserta didik melalui tugas tertulis.

Sikap artinya pendirian seseorang terhadap suatu peristiwa atas obyek. Skala sikap ini merupakan alat penilain yang mengukur pendirian seseorang seperti sangat setuju, ragu-ragu, setuju dan sangat tidak setuju. Contoh: setujukah kamu menyeberangkan orang tua di jalan raya, sedangkan kamu harus buru-buru ke sekolah? Hampir dapat dipastikan siswa akan selalu memilih jawaban yang baik- baik saja, meski mungkin siswa tidak akan melakukan 
tindakan tersebut dalam tindakan nyata. Inilah salah satu kelemahan mendasar 
yang sering terjadi pada aspek penilaian sikap, yaitu sulit diukur.

\section{b. Check list}

Check list merupakan suatu alat penilaian dimana pengisiannya dilakukan oleh guru dengan berdasarkan kepada hasil pengamatan terhadap perilaku siswa. Pada saat guru akan melakukan pengamatan, guru tidak perlu untuk memberitahu siswa terlebih dahulu bahwa perilaku mereka sedang diamati pada saat itu. Hal ini tentunya dimaksudkan untuk tetap menjaga kealamihan perilaku siswa, sehingga proses pengamatan bisa berjalan sesuai dengan prosedur yang diharapkan. Namun, pada hal- hal tertentu siswa memang perlu diberitahu sebelumnya agar siswa menjaga perilakunya.

\section{c. Quesioner}

Quesioner merupakan suatu alat penilaian dimana cara penyajian maupun pengerjaannya sepenuhnya dilakukan secara tertulis. Penyusunan angket/quesioner ini ditujukan untuk menyaring infomasi mengenai berbagai faktor yang berpengaruh terhadap prestasi belajar siswa.

\section{d. Catatan harian}

Catatan harian merupakan suatu catatan yang tentang perilaku siswa yang memiliki 
kaitan erat dengan perkembangan kepribadian siswa. Misalnya, catatan mengenai suatu perilaku khusus siswa, seperti suka terlambat, suka menyontek, suka membuat gaduh, dan suka 
mengganggu teman. Perilaku khusus yang dicatat tidak selalu berupa perilaku negatif. Perilaku positif yang tidak biasa dilakukan siswa pun perlu ditulis dalam catatan harian, misalnya siswa yang biasanya suka mengganggu teman tiba-tiba menjadi suka menolong teman, atau siswa yang biasanya sering membuat gaduh tiba-tiba menjadi pendiam di kelas.

e. Portofolio, adalah suatu kumpulan dari banyak nya tugas atau karya siswa yang sengaja dikumpulkan untuk menelaah proses dan perbaikan guna pencapaian kinerja siswa sesuai yang diharapkan oleh guru yang telah disesuaikan dengan kurikulum yang digunakan.

\section{Pengembangan Alat Penilaian Kognitif dan Non- Kognitif}

Taksonomi Bloom, dalam menyusun penilaian nonkognitif terbagi atas penilaian afektif dan penilaian psikomotor.Untuk dapat melengkapi pengetahuan Anda tentang alat penilaian kognitif dan non-kognitif, perhatikan pembahasan berikut ini!

\section{Pengembangan Alat Penilaian Kognitif}

a. Tes kognitif, terdiri dari tes objektif dan tes esai. Baik tes objektif maupun tes esai yang berbentuk tertulis dan bermanfaat untuk mengukur semua tujuan pembelajaran. Kedua bentuk tes tersebut dapat mendorong siswa untuk mempelajari 
konsep dasar dan untuk mencari solusi

permasalahan. Di samping itu, bentuk tes tersebut dapat menghasilkan skor 
yang nilainya tergantung pada objektivitas dan keterhandalan (reliability). Menurut Bloom, penilaian ranah kognitif ada enam gradasi. Keenam gradasi tersebut dijelaskan pada bagian berikut.

b. Pengetahuan, adalah kemampuan mengingat dari suatu rangkaian peristiwa yang telah dipelajari sebelum nya.

c. Pemahaman, adalah tingkat tes penerimaan berapa besar atau banyak materi atau makna akan suatu hal yang telah diterima oleh otak.

d. Penerapan, adalah kemampuan menerapka konsep pada kehidupan yang riil atau nyata..

e. Analisis, adalah kemampuan memilahkan kan hal - hal yang telah di fahami dengan hal - hal yang lebih difahami lagi.

f. Sintesis, adalah suatu tindakan yang dapat membuat suatu tindak lanjut yang tepat sasaran.

g. Evaluasi, adalah kemampuan diri untuk menilai dari hasil ujian yang telah disesuaikan dengan standart yang telah di telaah sebelumnya.

Adapun kata kerja yang digunakan dalam domain kognitif dideskripsikan pada tabel berikut: 


\begin{tabular}{|c|c|c|c|}
\hline & Jenis Hasil Belajar & Indikator-indikator & Cara Pengungkapan \\
\hline 1 & Pengetahuan & $\begin{array}{l}\text { Dapat menyebutkan/ } \\
\text { menunjukkan lagi. }\end{array}$ & Pertanyaantugasites \\
\hline 2 & Pemahaman & $\begin{array}{l}\text { Dapat menjelaskan/ } \\
\text { mendefnisikan. }\end{array}$ & Pertanyaanisoaltugas \\
\hline 3 & Penerapan & $\begin{array}{l}\text { Dapat memberi contoh } \\
\text { memecahkan masalah. }\end{array}$ & Tugasipersoalantes \\
\hline 4 & Analisis & $\begin{array}{l}\text { Dapat menguraikan } \\
\text { mengklasifikasikan }\end{array}$ & $\begin{array}{l}\text { Tugas/menganalisis } \\
\text { masalah }\end{array}$ \\
\hline 5 & Sintesis & $\begin{array}{l}\text { Dapat menyimpulkan kembali, } \\
\text { menggeneralisasikan }\end{array}$ & Tugasiperscalan \\
\hline 6 & Evaluasi & $\begin{array}{l}\text { Dapat menginterpretasikan/ } \\
\text { memberikan perfimbangan/ } \\
\text { penilaian }\end{array}$ & Tugasipermasalahan. \\
\hline
\end{tabular}

Ranah kognitif tersebut harus diperhatikan pada pengembangan alat penilaian matapelajaran PKn di SD. Perlu Anda ketahui bahwa model-model alat penilaian

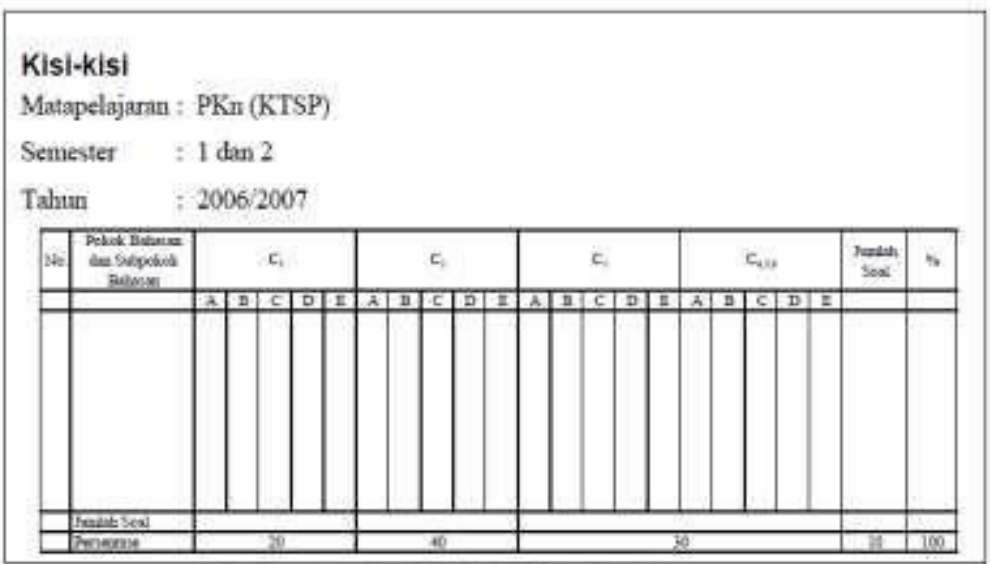

Tabel 3.1 Contoh tabel Kisi-Kisi Soal PKn SD

PKn SD dapat dikembangkan sesuai dengan kreasi guru dengan syarat tetap berpedoman pada kisi-kisi soal yang ada. Berikut dikemukakan contoh kisikisi soal PKn SD 
yang dikembangkan 
dalam aspek kognitif. Selanjutnya, setelah menentukan kisi-kisi soal PKn SD, dilakukan penyusunan model tes. Bentuk soal tes essai dan tes objektif pada aspek kognitif pada mata pelajaran PKn di SD dideskripsikan pada

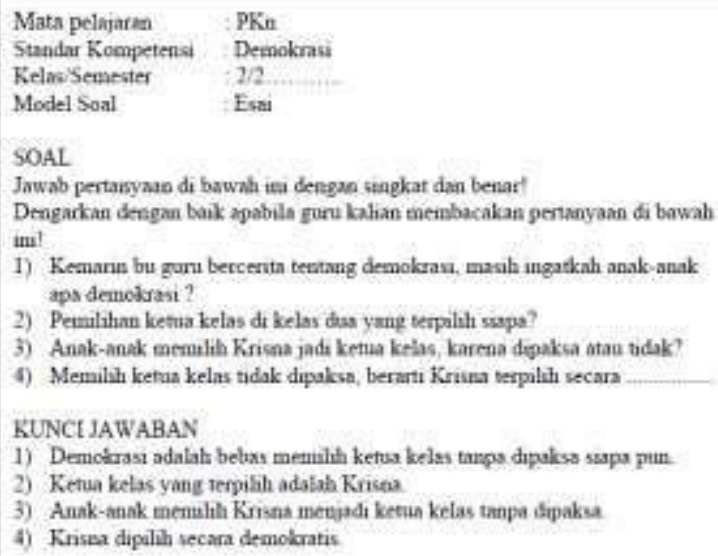

bagian berikut.

$\begin{array}{ll}\text { Mata pelajaran } & : \text { PKn } \\ \text { Standar Kompetensi } & : \text { Sumpah Pemuda } \\ \text { Kelas/Semester } & : 3 / 1 \\ \text { Model Soal } & : \text { Pilihan Ganda/Objektif Tes }\end{array}$

SOAL

Pilih salah satu jawaban yang dianggap paling benar!

1. Hari sumpah pemuda diperingati setiap tanggal....
a) 28 September
b) 28 Oktober
c) 28 Nopember
c) 28 Desember

2. Para pemuda yang mengikuti ikrar sumpah pemuda adalah....
a) Yong dari Jawa dan Sumatra
b) Yong dari Sulawesi dan Kalimantan
c) Yong dari Nusa tenggara dan Irian
c) Yong dari seluruh pelosok tanah air 


\section{Pengembangan Alat Penilaian Afektif}

Alat penilaian afektif, atau disebut juga dengan tes afektif, merupakan salah satu bagian dari tes nonkognitif. Domain afektif ini mencakup nilai, sikap, minat, dan perasaan. Penilaian untuk domain ini relatif sulit. Perlu Anda ketahui bahwa Bloom menggradasikan ranah afektif menjadi lima tingkatan sebagai berikut.

a. Penerimaaan, berhubungan dengan kesensitifan. Sebagai contoh, kemampuan mengakui adanya perbedaan-perbedaan.

b. Partisipasi, berhubungan dengan kesediaan memperhatikan. Misalnya, ikut berpartisipasi dalam suatu kegiatan.

c. Penilaian dan penentuan sikap, mencakup penilaian yang di dapat dari pendapat orang lain.

d. Organisasi, mencakup semua nilai yang dibuat acuan dalam hidup seseorang. Misalnya, menganggap nilai dalam suatu skala penilaian yang digunakan sebagai pedoman untuk bertindak.

e. Pembentukan pola hidup, mencakup segala sesuatu yang dijadikan acuan untuk mengubah atau mengatur hidup seseorang. Sebagai contoh,mempertimbangkan sesuatu dengan detail.

Dari kelima gradasi di atas juga dilaksanakan secara hierarkis, artinya gradasi 
kelima dapat dilakukan dengan baik apabila yang sebelumnya sudah terlaksana dengan baik. Kata kerja yang digunakan dalam domain afektif dapat Anda lihat pada tabel berikut : 


\begin{tabular}{|c|c|c|c|}
\hline & Jenis Hasil Belajar & Indikator-indikator & Cara Pengungkapan \\
\hline 1 & Penerimaan & $\begin{array}{l}\text { Bersikap menerima menyetuju } \\
\text { atau sebaliknya }\end{array}$ & $\begin{array}{l}\text { Pernyataan/tes/ } \\
\text { skala sikap }\end{array}$ \\
\hline 2 & Partisipasi & $\begin{array}{l}\text { Bersedia terlibat/partisipas } \\
\text { memanfaatkan atau sebaliknya }\end{array}$ & Tugas/observasi/tes \\
\hline 3 & Penilaian sikap & $\begin{array}{l}\text { Memandang penting/bernila } \\
\text { berfaedah/ indah/harmonis/ } \\
\text { kagum atau sebaliknya }\end{array}$ & $\begin{array}{l}\text { Skala sikap/ } \\
\text { Pernyataan }\end{array}$ \\
\hline 4 & Organisasi & $\begin{array}{l}\text { Mengakui/mempercayai/ } \\
\text { meyakinkan atau sebaliknya }\end{array}$ & $\begin{array}{l}\text { Skala sikap/ } \\
\text { tugas/ekspresif }\end{array}$ \\
\hline 5 & Pembentukan pola & $\begin{array}{l}\text { Melembagakan/membiasakan/ } \\
\text { menjelmakan dalam pribadi da } \\
\text { perilaku sehari-hari }\end{array}$ & $\begin{array}{l}\text { Skala sikap/ } \\
\text { tugas/ekspresif }\end{array}$ \\
\hline
\end{tabular}

Tabel 3.3 Kata Kerja dalam Domain Afektif dari Taksonomi Bloom

\section{Pengembangan Alat Penilaian Psikomotor}

Ranah psikomotor terdiri dari tujuh jenis perilaku. Ketujuh jenis perilaku tersebut dapat Anda cermati pada ulasan berikut ini.

a. Persepsi, mencakup segala hal yang di dasarkan padakekhususan nya setelah mengetahui perbedaan yang akan dipisahkan.Misalnya, pemilahan anak yang rajin dengan yang tidak rajin, yang nilai rapornya baik dengan yang kurang.

b. Kesiapan, mencakup segala hal yang berhubungan dengan cara penempatan diri seseorang baik secara rohani ataupun jasmani.Misalnya dalan PKn adalah mengamati 
tingkah laku seseorang dalam keseharian. 
c. Gerakan terbimbing, adalah kemampuan seseorang dalam melakukan suatu tindakan yang disesuaikan dengan instruksi yang diberikan oleh guru. Misalnya guru memberikan contoh bagaimana cara menghormati dan bersikap kepada orang lain terutama pada orang yang lebih tua.

d. Gerakan yang terbiasa, mencakup kemampuan memberi salam pada guru sebelum masuk kelas, ini sudah tidak usah dibimbing sudah biasa dilakukan.

e. Gerakan kompleks, menyinggung tentang taraf kemampuan cara bersikap dan bertingkah laku. Misalnya membantu teman yang kesusahan debgan cekatan.

f. Penyesuaian pola gerakan, mencakup kemampuan mengadakan penyesuaian dengan lingkungan, menyesuaikan diri dengan hal-hal yang baru.

g. Kreativitas, adalah kemampuan berkreasi yang didasarkan pada kemampuan diri nya sendiri.Misal cara bergaul dengan teman yang menyenangkan, cara menolong teman yang sakit, teman jatuh dengan sikap yang penuh keiklasan dan menyenangkan.

Kata kerja yang digunakan dalam domain afektif dapat Anda lihat pada tabel

berikut : 


\begin{tabular}{|l|l|l|l|}
\hline \multirow{2}{*}{ No } & Jenis Hasil & Indikator-indikator & Cara Pengungkapan \\
& Belajar & & \\
\hline 1 & Persepsi & Dapat menyiapkan diri & Tugas/observasi/tindakan \\
\hline 2 & Kesiapan & Dapat menirukan & Tugas/observasi/tes/tindakan \\
3 & Gerakan terbimbing & Dapat berpegang pada pola & Tugas/observasi \\
4 & Gerakan terbiasa & Menjadi lincah dan lancar & Tugas/tes/tindakan \\
5 & Gerakan kompleks & Dapat mengatur kembali & Tugas/tindakan \\
6 & Penyesuaian & Dapat menciptakan pola & Tugas/observasi \\
7 & Kreativitas & Menjadi kreatif dan cekatan & Tugas/observasi \\
\hline
\end{tabular}

Tabel 3.4 Kata Kerja dalam Domain Psikomotor dari Taksonomi Bloom

Dalam pembelajaran PKn SD tabel tersebut disesuaikan dengan karakteristik dan tujuan dari PKn sendiri, yaitu menanamkan nilai, norma dan moral untuk membentuk karakter warga negara yang baik yaitu warga negara yang tahu mau dan sadar akan hak dan kewajibannya. Ketujuh jenis perilaku tersebut mengandung urutan taraf keterampilan yang berangkaian dan bersifat runtut. Perilaku persepsi bergradasi paling rendah, sedangkan perilaku kreativitas paling tinggi. Perlu Anda ketahui bahwa perilaku yang gradasinya paling tinggi, menurut Bloom, akan tercapai setelah siswa melalui perilaku-perilaku rendah di bawahnya terlebih dulu. Siswa akan mampu berkreativitas kalau ia telah mampu melalui gradasi pertama (perilaku persepsi) sampai gradasi keenam (penyesuaian pola gerakan) dengan baik.

Ranah psikomotorik yang terdiri dari tujuh hierarkis tersebut dilukiskan oleh Dimyati seperti dalam Bagan 3.4 di atas. 


\section{Kesimpulan}

Penilaian PKn tidak hanya ditekankan pada domain kognitif saja, melainkan lebih ditekankan pada domain afektif tanpa meninggalkan domain kognitif danpsikomotor. Penyusunan model penilaian PKn ini kiranya perlu disosialisasikan kepada guru-guru SD dan guru-guru MIS, karena pada umumnya guru-guru tersebut masih melaporkan nilai PKn dalam buku rapot dengan sekedar menekankan pada nilai rata-rata tes formatif, sub-sumatif, dan sumatif dengan titik tekan pada domain kognitif saja.

Penilaian PKn di sekolah dasar hendaknya ditekankan pada nilai rata-rata afektif, kognitif, dan psikomotor secara menyeluruh sehingga sesuai dengan tujuan PKn itu sendiri. Dengan model penilaian seperti tersebut, diharapkan warga negara Indonesia menjadi warga negara yang baik, yaitu warga negara yang tahu, mau, dan sadar akan hak dan kewajibannya. Di samping itu, diharapkan kelak menjadi warga negara yang cerdas, terampil, dan berbudi pekerti luhur. 


\section{DAFTAR PUSTAKA}

Abidin, Yunus. 2016. Pembelajaran Membaca Berbasis Pendidikan Karakter. Bandung: PT Refika Aditama.

Akhmad Sudrajat.2009.Pengertian Pendekatan, Strategi, Metode, Teknik dan Model Pembelajaran. Bandung : Sinar Baru Algensindo.

Althof, W and Berkowits, MW. (2006). "Moral Education and Character Education: Tear Realationship and Roles in Citizenship Education". Journal o Moral Education.

Arsyad, Azhar. 2010. Media Pembelajaran. Jakarta: PT. Raja Grafindo Persada

Cogan, John J. 1998. Citizenship for The 21st Century: An International Perspective on Education. London: Creative Print and Design, Wales.

Djamarah, S. danZain, A. 2010.Strategi Belajar Mengajar. Jakarta: PT RinekaCipta

Faizah, Hadi., P. Sudharto P., dan Syafrudin. 2015. "Pengelolaan Sampah Rumah Tang ga BerbasisMayarakat (Studi Kasus di Kota Yogyakarta)", dalamhttp://eprints.undip.ac.id/17210/.

Hamalik, Oemar.2009.Perencanaan Pengajaran 
Berdasarkan Pendekatan Sistem.Jakarta:PT Bumi Aksara. 
Hamdani.2011. Strategi Belajar Mengajar.Bandung :

Pustaka Setia.

Ibrahim Syukur Abd dan Wahyuni Sri. 2013. Perencanaan

Pembelajaran Bahasa Berkarakter. Bandung : PT Refika Aditama.

Jihad, Asep dan Suyanto. 2015. Menjadi guru professional. Jakarta: Erlangga

Jurnal Penelitian dengan judul Membangun Karakter Siswa Melalui Kegiatan Intrakurikuler, Ekstrakurikuler, dan Hidden Curriculum oleh Prawidya Lestari dan Sukanti STAINU Purworejo, Jawa Tengah dalam http://journal.stainkudus.ac.id/index.php/jurnalPenel iti an/article/view/1367 diakses pada Senin, 2 Oktober 2017 pukul 13.09 WIB.

Lestari, Prawidya. 2016. Membangun Karakter Siswa Melalui Kegiatan Intrakurikuler, Ekstrakurikuler dan Hidden Curriculum (di SD Budi Mulia Dua Pandeandari Yogyakarta). Purworejo: Jurnal Penelitian Vol. 10 No. 1, Februari 2016.

Maliki. 2016. Bimmbingan Konseling Di Sekolah Dasar Sautu Pendekatan Imajinatif.Mataram : Kencana.

Musfiqon dan Nurdyansyah. 2015. Pendekatan Pembelajaran Saintifik. Sidoarjo: Nizamia Learning Center. 
Musfiqon. 2015. Mendesain Sekolah Unggul. Sidoarjo:

Nizamia Learning Center. 
Nana Sudjana.2010.Dasar-Dasar Proses Belajar Mengajar.Bandung: Sinar Baru, Al-Gensindo.

Neill, James. 2004. A Socio-cultural History of Outdoor

Education. http://wilder dom.html

Neill, James. 2006. C:IDocuments and Settings|Windowz

$X P \mid M y$

Documents|PhilosophyofoutdoorEducation.htmCo $\mathrm{m} / \mathrm{ps}$

ychoevolutionary/SocioCulturalHistoryOutdoor

Education.html.

NK, Roestiyah. 1998. Strategi Belajar Mengajar. Jakarta:

Bina Aksara

Noor, Rohinah M. 2012. The Hidden Curriculum. Yogyakarta: Insan Madani.

Nunu Mahnun.2012.Media Pembelajaran (Kajian terhadap Langkah-langkah Pemilihan Media dsn Implementasinya dalam Pembelajarannya).Fakultas Tarbiyah dan Keguruan UIN Suska Riau.

Pusat Kurikulum. 2009. Pengembangan dan Pendidikan Budaya \& Karakter Bangsa. Jakarta : Puskur.

Republik Indonesia. 2003. Undang-undang No. 20 Tahun 2003 Tentang Fungsi Pendidikan Nasional. Jakarta: Sekretariat Negara.

Rohiat. 2010. Manajemen Sekolah: Teori dan Praktik. 
Bandung: Refika Aditama. 
Rumiati. Penyusunan Silabus Dan Rencana Pelaksanaan Pembelajaran, Serta Pengaplikasian Keterampilan Dasar Belajar Mengajar Dalam Pembelajaran Pkn Di SD.

Sagala,S. 2010.Konsep dan Makna Pembelajaran.Bandung: Alfabeta

Samani, Muchlas dan Hariyanto. 2011. Konsep dan Model Pendidikan Karakter. Bandung : PT. Remaja Rosda karya.

Samiawan Conny. 1992. Pendekatan Keterampilan Proses : Bagaimana Mengaktifkan Siswa dalam Belajar. Jakarta

: Gramedia.

Santrock John W. . 2012. Psikologi Pendidikan / Educational Psychology. Jakarta : Salemba Humanika.

Sapriati, amalia. 2008. Pembelajaran IPA di SD. Jakarta: Universitas Terbuka

Sopiatin, Popi. 2010. Manajemen Belajar Berbasis Kepuasan Siswa. Bogor: Ghalia Indonesia.

Sudjana, N dan Rivai, A. 2010. Media Pengajaran. Bandung: Sinar Baru Algesindo

Sudjana, Nana.2009.Penilain Hasil Proses Belajar Mengajar. Bandung: Remaj Rosdakarya. 
Suryadi, Ace. 2009. Paradigma Pembangunan Pendidikan Nasional: Konsep, Teori dan Aplikasi dalam Analisis Kebijakan Publik. Bandung: Widya Aksara Press.

Syaiful, Sagala. 2012. Supervisi Pembelajaran. Bandung : Alfabeta.

Tarwiyah,Tuti.2012.Permainan Anak Betawi yang Menggunakan Nyanyian.Suku Dinas Kebudayaan Kota Administrasi Jakarta Selatan. Jakarta.

Trianto. 2007. Model Pembelajaran Terpadu dalam Teori dan Praktek. Surabaya: Pustaka IImu

Trianto. 2008. Mendesain pembelajaran kontekstual (contextual teaching and learning) di kelas. Jakarta : cerdas pustaka publisher.

W, Sri Anita. 2014.Strategi Pembelajaran di SD. Tanggerang Selatan: Universitas Terbuka

Widayanti, Ninik. 2001. Efektifitas Pembelajaran Geografi Melalui Metode Outdoor Study dalam Upaya Meningkatkan Minat Belajar Siswa. Buletin Pelangi Pendidikan, dalam http://pakguruonline.pendidikan.net.

Zuchdi, Darmiyati. (2011). Pendidikan karakter dalam prespektif teori dan praktik. Yogyakarta: UNY Press. 


\section{DAFTAR PUSTAKA}

Abidin, Yunus. 2016. Pembelajaran Membaca Berbasis Pendidikan Karakter. Bandung: PT Refika Aditama.

Akhmad Sudrajat.2009.Pengertian Pendekatan, Strategi, Metode, Teknik dan Model Pembelajaran. Bandung : Sinar Baru Algensindo.

Althof, W and Berkowits, MW. (2006). "Moral Education and Character Education: Tear Realationship and Roles in Citizenship Education". Journal o Moral Education.

Arsyad, Azhar. 2010. Media Pembelajaran. Jakarta: PT. Raja Grafindo Persada Cogan, John J. 1998. Citizenship for The 21st Century: An International Perspective on Education. London: Creative Print and Design, Wales.

Djamarah, S. danZain, A. 2010. Strategi Belajar Mengajar. Jakarta: PT RinekaCipta Faizah, Hadi., P. Sudharto P., dan Syafrudin. 2015. "Pengelolaan Sampah Rumah Tang

ga Berbasis Mayarakat (Studi Kasus di Kota Yogyakarta)", dalam http://eprints.undip.ac.id/17210/.

Hamalik, Oemar.2009.Perencanaan

Pengajaran Berdasarkan Pendekatan

Sistem.Jakarta:PT Bumi Aksara.

Hamdani.2011. Strategi Belajar Mengajar.Bandung : Pustaka Setia.

Ibrahim Syukur Abd dan Wahyuni Sri. 2013. Perencanaan Pembelajaran Bahasa Berkarakter. Bandung : PT Refika Aditama.

Jihad, Asep dan Suyanto. 2015. Menjadi guru professional. Jakarta: Erlangga Jurnal Penelitian dengan judul Membangun Karakter Siswa Melalui Kegiatan Intrakurikuler, Ekstrakurikuler, dan Hidden Curriculum oleh Prawidya Lestari dan Sukanti STAINU Purworejo, Jawa Tengah dalam http://journal.stainkudus.ac.id/index.php/jurnalPenelitian/article/view/1 
36 $I$ diakses pada Senin, 2 Oktober 2017 pukul 13.09 WIB. 
Lestari, Prawidya. 2016. Membangun Karakter Siswa Melalui Kegiatan Intrakurikuler, Ekstrakurikuler dan Hidden Curriculum (di SD Budi Mulia Dua Pandeandari Yogyakarta). Purworejo: Jurnal Penelitian Vol. 10 No. 1, Februari 2016.

Maliki. 2016. Bimmbingan Konseling Di Sekolah Dasar Sautu Pendekatan Imajinatif. Mataram : Kencana.

Musfiqon dan Nurdyansyah. 2015. Pendekatan Pembelajaran Saintifik.

Sidoarjo: Nizamia Learning Center.

Musfiqon. 2015. Mendesain Sekolah Unggul. Sidoarjo: Nizamia Learning Center.

Nana Sudjana.2010.Dasar-Dasar Proses Belajar Mengajar.Bandung: Sinar Baru, Al- Gensindo.

Neill, James. 2004. A Socio-cultural History of Outdoor Education. http://wilder dom.html

Neill, James. 2006. C:IDocuments and Settings|Windowz $X P \mid M y$ Documents|PhilosophyofoutdoorEducation.htmCom/psychoevolutionar y/So cioCulturalHistoryOutdoor Education.html.

NK, Roestiyah. 1998. Strategi Belajar Mengajar. Jakarta: Bina Aksara

Noor, Rohinah M. 2012. The Hidden Curriculum. Yogyakarta: Insan Madani.

Nunu Mahnun.2012.Media Pembelajaran (Kajian terhadap Langkah-langkah Pemilihan Media dsn Implementasinya dalam Pembelajarannya).Fakultas Tarbiyah dan Keguruan UIN Suska Riau.

Pusat Kurikulum. 2009. Pengembangan dan Pendidikan Budaya \& Karakter Bangsa. Jakarta : Puskur.

Republik Indonesia. 2003. Undang-undang No. 20 Tahun 2003 Tentang Fungsi Pendidikan Nasional. Jakarta: Sekretariat Negara.

Rohiat. 2010. Manajemen Sekolah: Teori dan Praktik. Bandung: Refika Aditama. Rumiati. Penyusunan Silabus Dan Rencana Pelaksanaan 
Pembelajaran, Serta

Pengaplikasian Keterampilan Dasar Belajar Mengajar Dalam Pembelajaran Pkn Di SD. 
Sagala,S. 2010.Konsep dan Makna Pembelajaran.Bandung: Alfabeta

Samani, Muchlas dan Hariyanto. 2011. Konsep dan Model Pendidikan Karakter. Bandung : PT. Remaja Rosda karya.

Samiawan Conny. 1992. Pendekatan Keterampilan Proses : Bagaimana Mengaktifkan Siswa dalam Belajar. Jakarta : Gramedia.

Santrock John W. . 2012. Psikologi Pendidikan / Educational Psychology. Jakarta : Salemba Humanika.

Sapriati, amalia. 2008. Pembelajaran IPA di SD. Jakarta: Universitas Terbuka

Sopiatin, Popi. 2010. Manajemen Belajar Berbasis Kepuasan Siswa. Bogor: Ghalia Indonesia.

Sudjana, N dan Rivai, A. 2010. Media Pengajaran. Bandung: Sinar Baru

Algesindo Sudjana, Nana.2009.Penilain Hasil Proses Belajar Mengajar.

Bandung: Remaj

Rosdakarya.

Suryadi, Ace. 2009. Paradigma Pembangunan Pendidikan Nasional: Konsep, Teori dan Aplikasi dalam Analisis Kebijakan Publik. Bandung: Widya Aksara Press.

Syaiful, Sagala. 2012. Supervisi Pembelajaran. Bandung : Alfabeta.

Tarwiyah,Tuti.2012.Permainan Anak Betawi yang Menggunakan Nyanyian.Suku Dinas Kebudayaan Kota Administrasi Jakarta Selatan. Jakarta.

Trianto. 2007. Model Pembelajaran Terpadu dalam Teori dan Praktek. Surabaya: Pustaka IImu

Trianto. 2008. Mendesain pembelajaran kontekstual (contextual teaching and learning) di kelas. Jakarta : cerdas pustaka publisher. 
W, Sri Anita. 2014. Strategi Pembelajaran di SD. Tanggerang Selatan: Universitas Terbuka 
Widayanti, Ninik. 2001. Efektifitas Pembelajaran Geografi Melalui Metode Outdoor Study dalam Upaya Meningkatkan Minat Belajar Siswa. Buletin Pelangi Pendidikan, dalam http://pakguruonline.pendidikan.net.

Zuchdi, Darmiyati. (2011). Pendidikan karakter dalam prespektif teori dan praktik. Yogyakarta: UNY Press. 


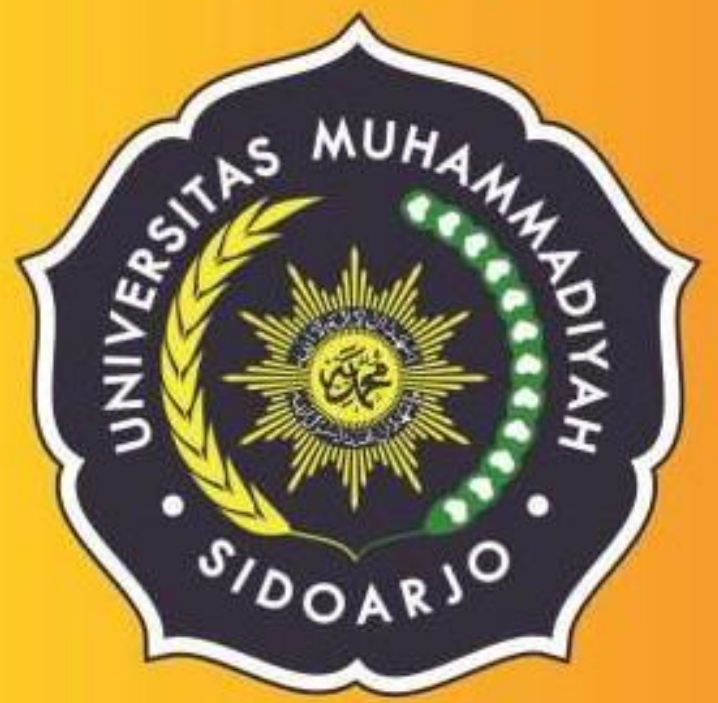

\section{UMSIDA PRESS}

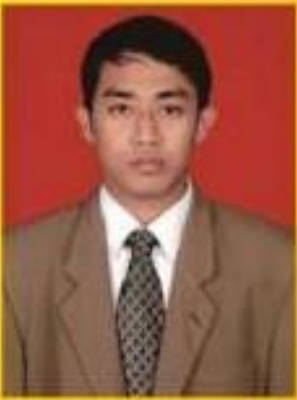

Feri Tirtoni, adalah seorang Magister S-2 Pendidikan Dasar UNESA, kelahiran Surabaya 15 Februari 1987, semasa kuliah penulis sangat tertarik sekali pada dunia pendidikan di level Sekolah Dasar dan menginginkan banyak sekali perubahan dalam konsep mengajar sehingga banyak tulisan yang dihasilkan penulis untuk membuat sebuah paradigma baru dalam mengajar PKn di SD. saat ini Penulis tercatat sebagai dosen tetap di Universitas Muhammadiyah Sidoarjo. Track record penulis antara lain sebagai penulis di pada International Conference : Trending Issues of School Education in Advanced Countries and Indonesia May 12, 2015. Serta menjadi Narasumber Workshop "Strategi Suskes Menuju Sekolah Adiwiyata Melalui Rangkaian Program Unggulan Sekolah Yang Berbudaya Dan Peduli Lingkungan" di beberapa instansi sekolah di Surabaya dan Sidoarjo. Penulis juga aktif dalam menulis pada beberapa jumal Nasional. Penulis juga teriibat secara aktif pada Program penulisan Buku Aiar Nasional 2016 Kementerian Riset, Teknologi dan Pendidikan Tinggi. Saat ini penulis sedang fokus pada proses penyelesaian buku selanjutnya dan aktif memberikan pelatihan "Strategi Creative Marketing For Excellent School di Beberapa Sekolah Mitra". Bagi pembaca yang ingin menghubungi penulis dapat dihubungi melalui email : feri.tirtoni@umsida.ac.id. 